\author{
UNIVERSIDADE DE SÃO PAULO \\ INSTITUTO DE PSICOLOGIA
}

FLÁVIA CRISTINA AMARO QUEIROZ

REPRESENTAÇÃO NO CAMPO DO TRAUMÁTICO: A ENFERMIDADE GRAVE NA INFÂNCIA E O IMPACTO SOBRE O DESENVOLVIMENTO

SÃO PAULO

2011 


\section{REPRESENTAÇÃO NO CAMPO DO TRAUMÁTICO: A ENFERMIDADE NA INFÂNCIA E O IMPACTO SOBRE O DESENVOLVIMENTO}

Tese Apresentada ao Instituto de Psicologia da Universidade de São Paulo, como Parte dos Requisitos para Obtenção do Título de Doutor em Psicologia.

Área de Concentração: Psicologia da Aprendizagem e do Desenvolvimento Humano

Orientadora: Prof ${ }^{\mathrm{a}}$ Dra $^{\mathrm{a}}$ Audrey Setton Lopes de Souza

\section{SÃO PAULO}

2011

QUEIROZ, F. C. A. Representação no Campo do Traumático: a enfermidade grave na infância e o impacto sobre o desenvolvimento. Tese Apresentada ao Instituto de Psicologia da Universidade de São Paulo para Obtenção do Título de Doutor em 
Psicologia, Área de Concentração Psicologia da Aprendizagem e Desenvolvimento Humano.

Aprovado em:

Banca Examinadora

Prof. Dr.

Instituição:

Julgamento:

Assinatura:

Prof. Dr.

Instituição:

Julgamento:

Assinatura:

Prof. Dr.

Instituição:

Julgamento:

Assinatura:

Prof. Dr.

Instituição:

Julgamento:

Assinatura:

Prof. Dr.

Instituição:

Julgamento:

Assinatura: 
Dedico este trabalho à minha família, meu terreno mais fértil.

\section{AGRADECIMENTOS}

À Profa. Dra. Audrey Setton Lopes de Souza, minha orientadora, pela generosidade dos ensinamentos e das contribuições, pela confiança e compreensão nestes anos de trabalho. Obrigada por me ajudar a ser, além de pesquisadora em psicanálise, esposa e mãe. 
Ao Instituto de Psicologia da Universidade de São Paulo, pela oportunidade de realização deste curso de Doutorado.

Ao Prof. Dr. Ulisses Alexandre Crotti, responsável pela Equipe de Cirurgia Cardíaca Pediátrica do Hospital de Base de S. J. Rio Preto, pelo incentivo e apoio fundamentais para a realização deste projeto.

À Psicanalista Sueli Zoccal Paro Barison, pela oportunidade de me acompanhar em mais essa jornada de desafios e desenvolvimentos. Obrigada por ajudar a fortalecer minha alma, pensar meus pensamentos e apropriar-me de meus recursos.

À Psicanalista Claudia Maria de Lucca Colturato Dalul, pelos ensinamentos e contribuições em supervisão, imprescindíveis para meu aprimoramento pessoal e profissional e, sobretudo, para a realização deste trabalho.

Ao meu marido, Florencio Queiroz Neto, pelo amor, compreensão, carinho, presença e incansável apoio ao longo destes anos de elaboração deste trabalho.

Ao meu filho, Arthur, por me ensinar a cada dia ser mãe e entender um pouco mais de psicanálise.

Aos meus pais, pelo apoio e sustento nos momentos difíceis e pela oportunidade de poder, com eles, compartilhar as alegrias.

RESUMO

QUEIROZ, F. C. A. Representação no Campo do Traumático: a enfermidade grave na infância. 2011. 130f. Tese (Doutorado) - Instituto de Psicologia da Universidade de São Paulo, São Paulo, 2011. 
O presente trabalho teve como objetivo investigar a dinâmica psíquica de crianças vítimas de uma enfermidade grave e a possibilidade de permitir maior mobilidade da dinâmica psíquica dessas crianças por meio da técnica lúdica e do trabalho de busca de representabilidade, a partir da premissa de que a enfermidade grave na infância é uma situação traumática dentre tantas outras possíveis. Delineamos, para tal entendimento, um percurso que se inicia nas primeiras inscrições psíquicas e na construção de representações e, em seguida, apresentamos a maneira como uma situação traumática pode fragilizar a mente. Enfatizamos a possibilidade de representação, mediante as intervenções psicanalíticas, partindo do princípio de que é por intermédio da condição simbólica que o indivíduo se desenvolve. Realizamos um estudo teórico-clínico de duas crianças que foram submetidas à operação para correção de cardiopatia congênita e, consequentemente, internação em unidade de terapia intensiva. $O$ estudo consistiu de intervenções psicanalíticas que privilegiaram o oferecimento de um continente com rêverie, com uma proposta de acompanhar a criança no confronto com questões que fogem da esfera de representações, por intermédio do brincar, favorecendo a não paralisação e o não congelamento de sua rede simbólica e de significados. O Procedimento de Desenhos-estórias foi utilizado no início e final do processo como apoio para as intervenções e avaliações. Por meio das intervenções psicanalíticas, dos recursos teóricos-técnicos utilizados, observamos algumas modificações na linha de representação dos conflitos e um início de mudança na forma das crianças brincarem e se expressarem graficamente.

Palavras-chave: Psicanálise, Representação, Trauma psíquico, Criança hospitalizada, Brincar.

\section{ABSTRACT}

QUEIROZ, F. C. A. Representation in the Field of Trauma: a serious illness childhood. 2011. 130f. Thesis (Doctor's Degree in Psychology) - Institute of Psychology, Universidade de São Paulo, São Paulo, 2011. 
This study aimed to investigate the psychological dynamics of child victims of a serious illness and possibility of allowing greater mobility of the psychological dynamics of these children through recreational technical and search representative from the premise that serious illness in childhood is a traumatic situation among many others possible. Outline for such an understanding, a journey that starts in the first registration and the construction of mental representations and then present how a traumatic situation may weaken the mind. We emphasize the possibility of representation by the psychoanalytic interventions, assuming that it is through the symbolic condition that the individual develops. We conducted a theoretical and clinical study of two children who underwent surgery for repair of congenital heart disease and, consequently, admission to the intensive care unit. The study consisted of psychoanalytic interventions which recommended the offer of a continent with reverie, with a proposal to accompany the child in confronting issues that are beyond the realm of representations, through the play, not favoring the strike and not freeze your symbolic condition. The Drawing-stories was used at the beginning and end of the process as support for interventions and evaluations. Through psychoanalytic interventions, theoretical-technical resources used, we observed some changes in the line representing the beginning of a conflict and change in the way children play and express themselves graphically.

Keywords: Psychoanalysis, Representation, Psychic trauma, Child hospitalized, Playing.

\author{
SUMÁRIO
}

Considerações Iniciais 09 
1.1 Explorando o Terreno... As Inscrições Psíquicas e o Campo das

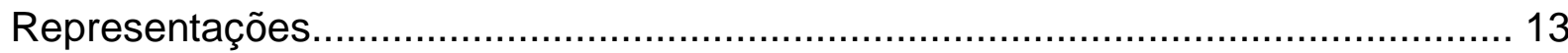

1.2 Aridez do Terreno... O Campo do Traumático................................................20

1.1.2 A Criança sob terreno árido: vicissitudes do traumático .............................36

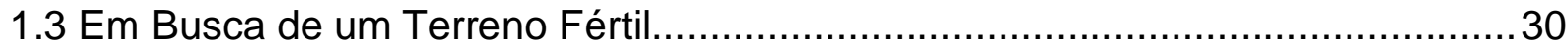

1.3.1 O brincar como propiciador de movimentação psíquica...........................45

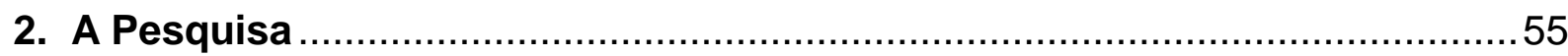

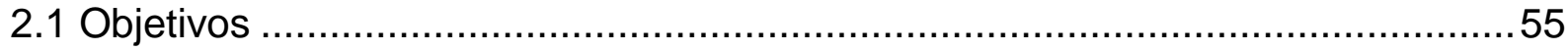

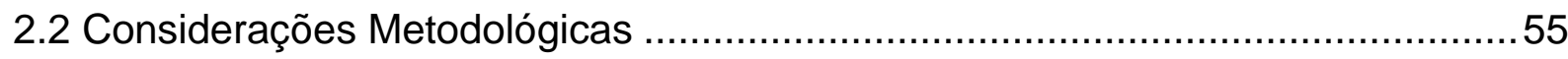

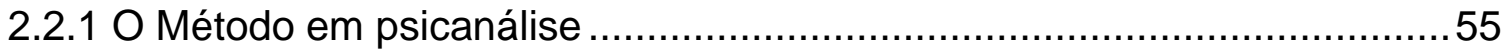

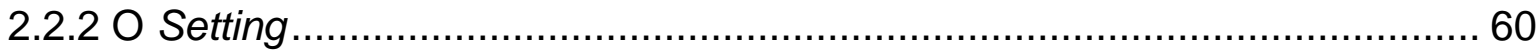

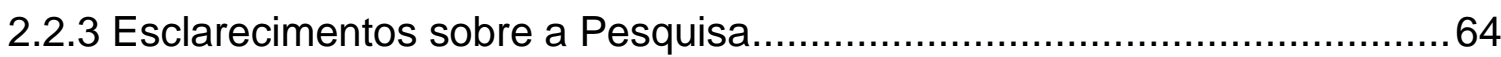

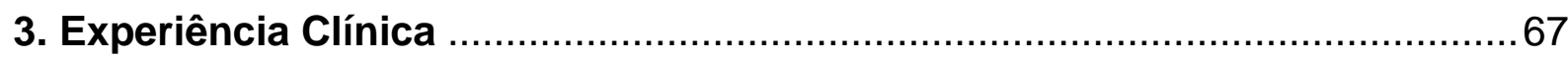

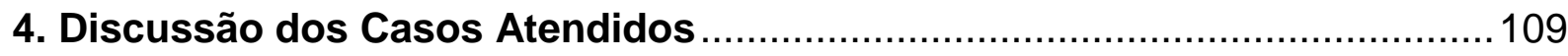

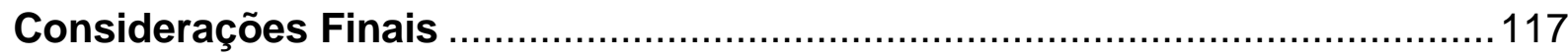

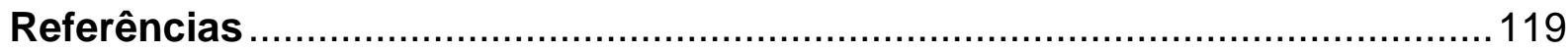

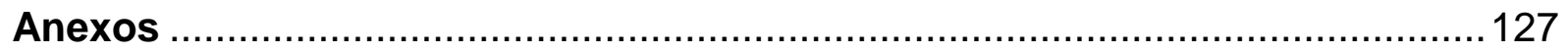




\section{CONSIDERAÇÕES INICIAIS}

A violência, em suas mais diversas faces, permeia a vida humana. Faz-nos deparar com limites e, tal qual a morte, impõe-nos uma realidade. Indagamos sobre a realidade como indagamos a vida e, nesse interrogatório infinito, a ciência está inserida procurando resolver os enigmas.

Um destes enigmas é como viver e conviver com a violência, impetuosa, hospedeira da força, do constrangimento e da coação. Violência que invade, causa excesso, inverte os sentidos, esgarça as capacidades de compreensão e que está ligada a qualquer vivência traumática em um aparelho psíquico despreparado.

Nessa esteira, a situação traumática pode ser associada à demasiada violência, uma vez que ameaça e atenta contra a vida do indivíduo. Assaltos, sequestros, acidentes, doenças, condições médicas graves, abusos físico e sexual são algumas situações em que a cena traumática se constrói, a ordem se desfaz e prevalece o caos. As capacidades de representações do aparato mental ficam estilhaçadas e não há como apreender ou captar por meio de uma forma coerente a cena do susto, do medo ou do terror; ficam ininteligíveis, sem acesso à dimensão da linguagem. Os sentidos não são assimilados e, tampouco, integrados à mente consciente, porque não podem ser processados por meio de um sistema de símbolos, códigos ou linguagem. A violência contida na situação traumática congela a rede de significados. Tal situação deixa o ego impossibilitado de pensar a experiência vivida.

Nesse tipo de contexto, as impressões sensoriais permanecem brutas e inalteradas. Pode ser o barulho do choque dos carros no momento do acidente, a luz do fogo na ocasião de uma situação de queimadura na pele ou a repetição sucessiva da cena traumática que provocou o susto e o medo. Em quaisquer umas dessas situações, o que opera é a ausência de palavras. Estas que estabelecem ligações, conexões e símbolos. 
Em ocasião anterior, o trabalho com crianças cardiopatas submetidas à operação para correção de más-formações cardíacas levantou vários questionamentos a respeito dos impactos e efeitos da doença grave para o desenvolvimento das crianças. A cardiopatia, muitas vezes, gerava duas condições adversas, uma crônica e outra aguda. A situação crônica podia ser vista diretamente pelos sinais e sintomas da doença, tanto físicos (cianose, fatigabilidade, arritmias, hipodesenvolvimento) quanto psicossociais (insegurança, dependência, comportamentos regredidos). A situação aguda caracterizava-se pela necessidade de ser submetida a operações de grande porte e a intervenções de alto risco com ameaça real de morte e, na sequência, dias de internação em unidade de terapia intensiva. O trabalho, realizado por meio de acompanhamentos no hospital com as crianças e suas famílias, resultou em um préestudo sobre os impactos psicossociais dessa condição para 0 ajustamento psicossocial da criança e, em seguida, em um desenvolvimento da dissertação de mestrado (AMARO DA SILVA, 2006).

O propósito da dissertação foi compreender a apresentação clínica do "Transtorno de Estresse Pós-traumático" (TEPT), como consequência a um estressor severo, com a psicodinâmica da experiência traumática. Um caso ilustrativo balisou as hipóteses teóricas levantadas à respeito da potencialidade traumática advindas de situações de ameaça e risco, como uma doença ou uma condição médica grave na infância. A criança foi atendida por mim para avaliação pré e pós-operatórias enquanto estava internada no hospital. Duas novas avaliações foram feitas em outros dois momentos: dois meses e dois anos após a alta hospitalar.

No ultimo encontro, após uma abordagem a respeito de sua operação, solicito à criança um desenho, da mesma maneira como em intervenções anteriores e ela não se move. Após algumas tentativas, permanece muda e resistente. Sinto a criança paralisada em suas associações, não podendo sequer se expressar graficamente. Muitos minutos se passam, ela esfrega as mãos umas às outras com angústia e nenhuma interpretação da minha parte surte um outro efeito. Quando peço para que ela se aproxime e digo que ela não está só, que estamos juntas ali, novamente, como 
estivemos em outros momentos quando ela operou, ela levanta e se senta espontaneamente no meu colo e, a partir de então, começa desenhar.

Dois anos depois, reencontro essa criança, aparentemente saudável, percebo que em mim permaneceram algumas questões: o que acontecera no momento da lembrança e daquela experiência? As representações falharam? O registro só pôde, nesse caso, partir do sensório (sentar-se no meu colo, sentir-se fisicamente acolhida)? Por intermédio desse contato, outras questões surgiram: como é possível compreender e auxiliar indivíduos que são submetidos a experiências traumáticas para que o desamparo vivido, em muitas dessas situações, não os deixe paralisados? Que tipo de experiência é essa? Como modificá-la? A modificação envolve uma possibilidade de representação? O que acontece quando a representação não cumpre sua função? Com quais teorias e recursos contar?

O interesse de compreender o que acontece com essas crianças operadas do coração surgiu a partir da premissa de que essa é uma situação potencialmente traumática dentre tantas outras possíveis. A criança referida foi avaliada em apenas quatro encontros, mediante desenhos entrevistas com os pais, apresentava um tipo de cardiopatia "simples" como era apontada pelos médicos da equipe, embora envolvesse intervenções invasivas e procedimentos de grande porte. O papel das avaliações, juntamente com a importância da intervenção do psicólogo, pareceu-nos evidente, uma vez que foi possível para essa criança expressar seus medos e angústias emergentes. Contudo, nossa hipótese é que essa mesma criança teria se beneficiado de algumas intervenções psicanalíticas após a operação realizada.

O estudo e o atendimento clínico de crianças cardiopatas ajudar-nos-iam na compreensão e no auxílio a outras situações de doenças e condições potencialmente graves em que o perigo de morte é iminente e o potencial traumático ronda quando o que se pretende é restabelecer a vida.

Delineamos, para tal entendimento, um percurso que se inicia nas primeiras inscrições psíquicas e na construção de representações e, em seguida, apresentamos a maneira como uma situação traumática pode fragilizar a mente. Enfatizamos a 
possibilidade de representação, mediante intervenções psicanalíticas, partindo do princípio de que é por intermédio dela (representação) que o indivíduo se desenvolve.

Desse modo, a primeira parte do trabalho procura contextualizar e nortear o leitor sobre os caminhos que percorremos e desenvolvemos por meio de uma introdução ao nosso tema de interesse. Iniciamos com as primeiras inscrições até como as representações vão se formando e constituindo o psiquismo e, em seguida, como este funciona diante das vivências traumáticas. A vivência que, em especial, abordaremos será a da hospitalização e a de operações de grande porte em crianças, para tanto, elucidaremos as especificidades e particularidades do tema no cenário infantil. Concluímos essa parte introdutória com a intervenção psicanalítica, nosso ponto de especial interesse.

A segunda parte do trabalho priorizou a pesquisa em psicanálise, apresentação de um caso clínico e outros fragmentos de casos que fundamentaram e balizaram o trabalho que nos possibilitou pensar a intervenção psicanalítica. Nesta parte, faremos algumas considerações sobre o método em questão e o desenho da pesquisa.

$\mathrm{Na}$ terceira parte deste trabalho, procuramos discutir e explorar os recursos, técnicas e compreensão disponíveis, dentro da psicanálise, para o auxílio a essas crianças com 0 interesse premente de verificar por meio das intervenções psicanalíticas, em enquadres diferenciados, se é possível observar algum movimento de elaboração da situação potencialmente traumática. 


\section{1 - APORTE TEÓRICO}

\subsection{EXPLORANDO O TERRENO... AS INSCRIÇÕES PSÍQUICAS E O CAMPO DAS REPRESENTAÇÕES}

Discorrer sobre o campo das representações em psicanálise nos remete, em primeira instância, à obra freudiana, uma vez que a idéia da representação esteve, desde o início, no trabalho sobre afasias e fortemente presente nos escritos posteriores de Freud (1886-89/1996a). Freud, indubitavelmente, inaugurou o tema da representação dentro da psicanálise, mas outros pensadores não só consideraram suas descobertas da época como também a revisaram e a reatualizaram inúmeras vezes, expandindo suas concepções. Winnicott (1956/2000) evidenciou o caráter traumático das faltas maternas para a formação do psiquismo infantil, Ferenczi (1873-1933/2003) apontou a importância de relações nutridoras em detrimento daquelas que podem ser traumatizantes, bem como a não-representação nos "casos-difíceis", Klein enfatizou a importância da simbolização e da escotomização da vida psíquica e Ogden (2006) focou as relações traumatizantes, os estados primitivos da mente e a irrepresentabilidade. Também outros autores, tais como Bolognini (2007) e Botella e Botella (2002), também margearam a esfera do irrepresentável.

Na teoria freudiana, o tema da representação ganha vigor no momento em que se ocupa em estabelecer uma via de conexão entre o biológico e o psíquico e estudar as forças pulsionais, no trabalho "Os Instintos e suas Vicissitudes" (FREUD, 19141915/1996b), o primeiro de cinco artigos sobre metapsicologia.

\footnotetext{
${ }^{1}$ Tradução da Edição Standard Brasileira das Obras Completas de S. Freud do Original em Alemão "Trieb und Triebschicksale" equivalência à " A Pulsão e seus Destinos"
} 
A pulsão, forças motrizes que emanam de dentro do organismo, ocorre num órgão ou parte do corpo e, tal qual uma necessidade, exerce uma pressão que sempre impele uma satisfação. Freud a descreve como

[...] um conceito situado na fronteira entre o mental e o somático, como o representante psíquico dos estímulos que se originam no interior do organismo e alcançam a mente, como uma medida da exigência feita à mente no sentido de trabalhar em consequência de sua ligação com o corpo (FREUD,1914-1915/1996b, p.127).

Mais adiante, em "O Inconsciente" (1914-1915/1996c), ele relata que a pulsão nunca pode se tornar objeto da consciência, apenas a idéia que a representa. A pulsão e a representação estariam sempre em relação, uma vez que a pulsão é representante (Repräsentant ou Repräsentanz) psíquico dos estímulos endossomáticos, isto é, um representante (Repräsentant ou Repräsentanz) do corpo no psiquismo. Caberia à pulsão a articulação que, segundo Garcia-Roza (2000), justificaria a Freud concebê-la como um conceito fronteiriço entre o psíquico e o somático. O autor aponta como a confusão aqui se estabelece, pois que a representação (Vorstellung) no psiquismo se dá mediante uma idéia, considerando, assim, que a pulsão é representada psiquicamente por seus representantes. A expressão Vorstellungrepräsentanz significa "o que representa (aqui o que representa a pulsão) no domínio da representação" (LAPLANCHE E PONTALIS, 1991, p. 455)².

Para a teoria freudiana, Vorstellungrepräsentanz tem relação com o inconsciente e com as pulsões, uma vez que é por intermédio dos estudos sobre o recalque e sobre o inconsciente que essa noção é utilizada com mais clareza. Freud escreve no texto "O

\footnotetext{
${ }^{2}$ É possível verificar que são duas palavras distintas do alemão traduzidas por duas palavras próximas para o francês: représentant-représentation, quanto para o português: representante-representação.
} 
Inconsciente" que "(...) se a pulsão não se prendeu a uma idéia ou não se manifestou como um estado afetivo, nada podemos conhecer sobre ela (...)" (FREUD, 191415/1996c, p.182). Tem-se que o representante psíquico da pulsão abarca tanto a idéia (Vorstellungsrepräsentanz) quanto o afeto (Affekt). A junção de um representante psíquico com uma representação de coisa preexistente pode resultar tanto em um representante-representação, um representante ideativo (Vorstelluntgsrepräsentanz), quanto em um afeto, sendo estes, dois outros componentes do inconsciente (GREEN, 2008).

É preciso esclarecer que Freud (1914-15/1996c) distingue dois tipos de representação (Vorstellung): representação da coisa e representação da palavra. Representação da coisa consiste da catexia de imagens de memória das coisas ou dos traços de memória remotos dela derivados. Quando esta é hipercatexizada, ou traduzida em palavras, a representação é consciente, de maneira que abrange a representação da coisa mais a representação da palavra. Quando permanece apenas a representação da coisa, ela permanece como uma representação inconsciente. No primeiro e no segundo casos, os processamentos de energia são diferentes. Por ora, apra-nos saber que no primeiro, típico dos processos inconscientes, a energia flui livremente por intermédio das representações, é denominado de processo primário (representações de coisa) e, no outro, no qual a energia é hipercatexizada e provoca uma organização psíquica mais elaborada, é denominado de processo secundário (representação de palavra). Retomaremos estes processos mais adiante.

Para Freud, as palavras consistiriam de elementos cinestésicos, táteis e visuais reunidos em um processo associativo complexo cujo significado dar-se-ia ao associarse a uma apresentação de objeto que, por sua vez, também se constitui de um complexo de associações visuais, acústicas, táteis, cinestésicas; entretanto, ainda no conjunto de artigos sobre "O Inconsciente" (1914-15/1996c), Freud dirá que a imagem visual é a que representa o complexo associativo do objeto e, por sua vez, a imagem acústica representa o complexo associativo da palavra. Uma representação de objeto está associada simbolicamente à representação de palavra. A representação de coisa alcança a qualidade de representação palavra, por meio do sistema perceptivo e 
associa-se a um objeto, passando, então, a reconhecê-lo como tal. Representações que não alcançam a qualidade de palavra permanecem inconscientes, submetidas, portanto ao recalque. Desse modo, um representante psíquico somado a uma representação da coisa (inconsciente) pode resultar tanto em um afeto quanto em um representante ideativo.

Afeto e representante ideativo são independentes. O representante ideativo pode ser recalcado, mas o afeto não. $O$ afeto tem que estar ligado a uma idéia. Freud (191415/1996c, p. 183) refere que "idéias são catexias - basicamente traços de memória enquanto que os afetos e as emoções correspondem a processos de descarga, cujas manifestações finais são percebidas como sentimentos". Em sequência, relata que as representações podem ser inconscientes, mas não os afetos e que é da natureza das emoções estarmos cônscios delas. Em virtude disso, no recalque, ocorre uma separação entre o afeto e o representante ideativo, cada um destes percorrendo destinos diferentes. Assim, o representante psíquico da pulsão pode tanto vir à consciência e ser reescrito, rearranjado e retranscrito (FREUD, 1886-1899/1996d) quanto não ser assumido por ela e permanecer recalcado (FREUD, 1915-16/1996e).

Podemos pensar, então, que as representações contidas no inconsciente são traços de memória, mas protegidos pelo recalque. Essa memória, tão importante em toda obra freudiana, é o que fundamenta o aparato psíquico, o que significa que o aparelho psíquico não é dado desde as origens. Freud (1886-1899/1996d) aponta para os registros enquanto conquistas sucessivas de fases da vida. $O$ aparelho psíquico se constitui, a partir da experiência do sujeito, de maneira que, na mais tenra experiência da infância, enquanto ainda bebê, o ser humano tem inscritos, no seu aparelho mental, ainda rudimentar, traços de memórias de experiências.

O ser humano, como um ser de pulsão, defronta-se, a todo o momento, com algo que emerge de dentro do organismo em busca de uma leitura e de um significado para minimizar o desprazer. Desde o nascimento, estamos submetidos a essas forças que emanam de dentro exercendo uma pressão em busca de descarga, de maneira a aliviar tal pressão que age sob forma de uma excitação. Essas forças são misturadas às 
vivências somáticas. O bebê que chora à espera de um alimento, busca-o e se sente saciado ao "encontrá-lo", já tem registrado, no seu psiquismo, traços de memória dessas primeiras experiências. Esses traços de memória vão constituindo as primeiras inscrições.

As inscrições, como desenhos primitivos feitos nas cavernas e nas pedras da antiguidade, funcionam na mente também como os primeiros signos, em uma época também primeva e são fundamentais para a constituição da memória e, consequentemente, do psiquismo.

Nos escritos sobre "Projeto para uma psicologia científica" (1886-99/1996d), Freud menciona que a vivência de satisfação, como a do bebê que sacia sua fome, é acompanhada de uma sensação de prazer e que esta, por sua vez, inaugura um movimento de desejo no bebê de tentativas de encontrar sensações semelhantes. A sensação de prazer deixa marcas que se constituem em traços perceptivos (ou inscrições) que passarão exercer uma função de juízo para as experiências subsequentes da vida do indivíduo. Isso significa que haverá no indivíduo um registro da sensação de prazer que será acionado sempre que for preciso. Essa sutil passagem das necessidades biológicas para um mundo de desejos e de fantasias no infans é responsável pelo início da construção de representações. Essas representações são fundantes e determinantes, pois o objeto concreto poderá ir de encontro à imagem da sensação prazerosa desse objeto (ROCHA, 1998). Pode-se verificar o contrário em indivíduos com estrutura neurótica e psicótica. Não há sensações de prazer devido a um objeto faltoso e não há vivência de satisfação. Nestes casos, também não se forma um tecido representacional suficientemente bom ou, então, não há representação sobre esta questão também retornaremos mais adiante.

Verifica-se, na teoria freudiana, desde muito cedo, que o aparelho psíquico constitui-se de representações sejam elas conscientes ou inconscientes. O campo de trabalho pelo qual a psicanálise se consolidou foi o da interpretação, a partir da premissa de que o psiquismo inconsciente é da ordem do significado. 
É sabido que o trabalho da análise freudiana, nesse sentido, é o de tornar consciente o inconsciente, mediante a busca de significado para o que foi perdido ou recalcado e que, para alívio do sofrimento e dos sintomas, é necessário que o paciente consiga transformar em representação de palavras 0 que seriam apenas representações de coisas (excitações sem o registro das representações de palavra). Podemos, então, dizer que há uma falha na memória gerada pelo recalque e que seu preenchimento se dará pela produção do sintoma. O sintoma seria, assim, conforme Laplanche e Pontalis (1991), indícios de um retorno do recalcado e um dos pontos chave de que se ocupa a psicanálise: o simbólico. O sintoma é da ordem do simbólico como é o sonho: "um modo de representação indireta e figurada de uma idéia, de um conflito e de um desejo inconscientes" (LAPLANCHE E PONTALIS, 1991, p. 481). Por meio do trabalho do simbólico, torna-se possível trazer à tona um acontecimento esquecido, em geral, um registro mnêmico de uma experiência que fora incapaz de ter acesso à consciência.

Todavia, se é por volta de 1915 que Freud se preocupa com a representação, por intermédio dos artigos sobre Metapsicologia (em "Os Instintos e suas Vicissitudes" e "O Inconsciente") é por volta de 1920, com o avanço da teoria e a entrada na nova dualidade pulsional (vida e morte), que a questão da representação é colocada em xeque. Freud especula sobre a pulsão de morte e afirma que, ao contrário das pulsões de vida que têm muito mais contato com nossa percepção interna, a pulsão de morte é discreta, silenciosa e, portanto, sem representação. Sobre esta questão Freud não discorrerá, não há mais avanços em sua teoria à respeito da não representação ou do irrepresentável. Todavia, Green (2008), cuja obra investiga cuidadosamente o que o autor denominou de "trabalho do negativo", abarcando a não-representação, apontanos para esse tema relacionando alguns "traços do negativo" em Freud (GREEN, 2008, p.260), entre eles, o próprio conceito de "in-consciente" e o imenso continente da pulsão de morte.

Podemos considerar que a psicanálise freudiana é pautada na representação e no significado e que os estudos pós-freudianos avançam sobre o tema da nãorepresentação. Nas contribuições de Freud, relatadas em seu artigo "Construções em 
Análise" (FREUD, 1937-39/1996f), o autor se ocupa das construções e reconstruções em análise, tal qual o arqueólogo procede nas escavações. Essa passagem ilustre de Freud levanta várias problematizações, entre elas, as construções duvidosas, das quais o analista não tem garantia. Não entraremos em detalhes sobre esses apontamentos. Um exame detalhado do artigo, todavia, revela que Freud está também abordando, sutilmente, questões não representadas, porém ainda não exploradas por ele, como segue no escrito subsequente

O caminho que parte da construção do analista deveria terminar na recordação do paciente, mas nem sempre ele conduz tão longe. Com bastante freqüência não conseguimos fazer o paciente recordar o que foi reprimido. Em vez disso, se a análise é corretamente efetuada, produzimos nele uma convicção segura da verdade da construção, a qual alcança o mesmo resultado terapêutico que uma lembrança recapturada. O problema de saber quais as circunstâncias em que isso ocorre e de saber como é possível que aquilo que parece ser um substituto incompleto produza todavia um resultado completo - tudo isso constitui assunto para uma investigação posterior (FREUD,1937-1939/1996f, p.284).

Esse trecho, nos leva a pensar em assuntos atuais como as noções de zonas não representadas no psiquismo, espaços aos que o analista não consegue facilmente ter acesso. Tais construções permitem que uma história dotada de objetos mnêmicos, muitas vezes, pouco estruturados, como reminiscências de cheiros, sons, imagens de intensa carga afetiva, possam ganhar um espaço, simbolizado, no psiquismo ou, em outras palavras, algo que pode vir a ser representado.

No modelo que usamos para pensar como as inscrições se formam e como por meio delas o indivíduo constrói uma trama de representações, podemos pensar que o bebê que deseja um objeto que nunca é encontrado ou satisfeito não terá o registro da presença do objeto, mas poderá ter sim um registro pelo inverso, no negativo (GREEN, 2008). Dessa maneira, não encontra o objeto de satisfação e não terá registro da 
sensação de prazer, também não poderá ter a sensação da presença do objeto na sua ausência - será sempre faltante. Nesses indivíduos, muitas vezes, após longos anos, ainda que o objeto se apresente, ele não será reconhecido. Assim, esse objeto sempre faltoso, fruto de traços da não-representação e do irrepresentável, aproxima-se da esfera do traumático, conteúdo que abordaremos a seguir.

\subsection{ARIDEZ DO TERRENO... O CAMPO DO TRAUMÁTICO}

As formulações sobre a questão do trauma foram extensivamente difundidas, nos últimos anos, pelas escolas de psicanálise mundo a fora. Todavia, retomaremos alguns ensinamentos da teoria freudiana sobre o tema. Nosso ponto de interesse, para fins de entendimento deste trabalho, fundamenta-se, especialmente, nas idéias do trauma relacionadas ao aspecto econômico ${ }^{3}$, fundamento este localizado na teoria freudiana após a década de 20. Este parece ser o cerne das questões sobre o trauma, relevante até os dias atuais: o aparelho mental necessita de um equilíbrio ótimo e o trauma está relacionado a um estímulo intenso e violento que invade a mente do indivíduo causando um excesso, desequilibrando o aparelho mental, tornando-o incapaz de suportar, conter e pensar a experiência vivida.

O ponto de vista econômico está relacionado a quantidades de excitação ou de energia. Desde o Projeto para Uma Psicologia Científica (1886-99/1996d), em que o aparelho neuronal aparece como esboço do que seria mais tarde o aparato psíquico, Freud elucida todo um esquema de funcionamento da mente que parte de uma

\footnotetext{
${ }^{3}$ Freud menciona, em seu artigo sobre O Inconsciente (1914-1915/1996c), o conceito dinâmico dos processos mentais, que leva em consideração o dinamismo das pulsões e o topográfico, que considera a topografia psíquica, ou seja, a existência de três sistemas psíquicos do funcionamento mental [inconsciente, pré-consciente e consciente]; mas, em Além do Princípio do Prazer (1925$26 / 1996 \mathrm{~g}$ ), Freud constrói novo alicerce para o entendimento da teoria do trauma ao manifestar que os processos mentais são descritos e entendidos, não somente dos pontos de vista topográfico e dinâmico, como havia mencionado até então, mas também, por intermédio do ponto de vista econômico.
} 
concepção quantitativa, ou seja, "de uma excitação neuronal como uma quantidade em estado de fluxo" (p. 348). Não nos deteremos aqui nas concepções do Projeto, interessa-nos saber que as quantidades de excitações [ou energia] presentes na mente são circulantes e poderão ser sentidas por um aumento de prazer ou diminuição do mesmo (desprazer).

Há uma tendência do aparelho mental a se manter com uma quantidade de excitação o mais baixo o possível, ou se manter constante (denominado princípio de constância) e evitar o aumento de tensão a todo custo (princípio do prazer). Qualquer estado desagradável que surge é acompanhado por uma tensão, ou seja, um aumento de desprazer. A percepção da tensão (desprazer) "pode ser uma pressão por parte de instintos insatisfeitos, ou ser a percepção externa do que é aflitivo em si mesmo ou excitando expectativas desprazerosas no aparelho mental, isto é, que é por ele reconhecido como um perigo" (FREUD, 1925-26/1996g, p.21).

Embora regido pelo princípio do prazer, o funcionamento mental não é por ele dominado. Se assim o fosse, Freud relataria que os processos mentais seriam sempre acompanhados por prazer ou conduzidos ao mesmo. O autor esclarece-nos este ponto afirmando que o princípio de prazer é próprio de um método primário de funcionamento (processo psíquico primário) que conduz aos processos psíquicos do sistema inconsciente, cujo núcleo consiste de impulsos carregados de desejo (FREUD, 191415/1996b). Sob o ponto de vista da autopreservação do organismo, o princípio do prazer, ineficaz ou, até mesmo, perigoso, dá lugar ao princípio de realidade, no qual a obtenção do prazer ou satisfação não é abandonada, mas sim adiada. O princípio de realidade é por Freud descrito como um método secundário de funcionamento mental (processo psíquico secundário), no qual o pensamento e as considerações pela realidade estão presentes. Portanto, é um método de funcionamento mais refinado e que exige um trabalho por parte do ego. Sobre estes processos, primário e secundário, retornaremos mais adiante.

Tendo em vista estas noções, Freud propõe, por volta de 1920, que o psiquismo seja pensado como uma vesícula viva, carregada de poderosas energias, cuja 
superfície esteja voltada ao mundo externo. A vesícula é suscetível ao recebimento desses estímulos externos e seria por eles destruída se não dispusesse de um envoltório endurecido funcionando como uma barreira protetora, denominada de dispositivo de pára-excitação. O psiquismo se vale dessa membrana protetora contra estímulos que impede a propagação de uma grande quantidade de energia no interior do aparelho ou garante que a mínima parte seja expelida. Esse escudo é vital para a sobrevivência do aparelho psíquico, pois preserva o modo especial de energia que nele se opera. Dessa maneira, o modelo de Freud sugere que a energia externa só possa chegar a outras camadas do aparelho mental com um fragmento de sua intensidade original, a menos que a intensidade seja forte o bastante para irromper a barreira protetora.

Uma falha ou uma deficiência na membrana protetora (dispositivo de páraexcitação) expõe o aparelho psíquico a uma enorme quantidade de energia. Esse rompimento acarretaria magnitudes incontroláveis de afeto (energia), inundando o ego. Quaisquer excitações provindas de fora, poderosas o suficiente para ultrapassar 0 escudo protetor, são consideradas, nesse modelo, como traumáticas. A perturbação no funcionamento de energia é sentida por meio do predomínio de sensações de desprazer. Não tendo como impedir essa inundação, o princípio do prazer é posto fora de ação. O problema surge na tentativa de dominar as quantidades de estímulos que irromperam; converter a energia livre de dentro do aparato mental em catexia quiescente, ou seja, vinculá-las psiquicamente (FREUD, 1925-26/1996g), ligá-las às representações.

Freud toma como base as noções propostas por Breuer e dele apreende o termo quiescente. Uma energia vinculada, que corre dentro do aparelho mental e que circula entre os sistemas, é criada por meio de um estado de fluxo livre para um estado quiescente. Afetos são quantuns de energia que correm soltos, circulam no aparelho mental, já catexias são idéias, são elas que se vinculam aos afetos e impedem que a energia corra livre em abundância no aparelho mental. Quanto mais alta a catexia quiescente do sistema, maior a chance de se vincular as idéias aos afetos. Vincular 
psiquicamente a energia livre seria, então, ligar afetos às idéias e isso é possível somente mediante representações.

Quanto mais baixa a catexia do sistema, menor seria seu poder de vinculação e, portanto, menor a capacidade de recebimento de energia na mente acarretando maior vulnerabilidade à barreira protetora de estímulos.

Catexias quiescentes são próprias de um modo secundário do funcionamento mental, que depende de um trabalho das partes mais elevadas e refinadas do aparelho psíquico. Já a energia livre, pertencente ao processo primário, o qual já mencionamos conduzir aos processos do sistema inconsciente, pressiona no sentido de descarga. $O$ trabalho do processo psíquico secundário é, portanto, contrário à descarga de excitação e sempre a favor de promover uma condição de pensamento, uma vez que o processo secundário é regido pelo princípio da realidade. A vinculação que o processo secundário busca é a de ligação entre as idéias sem que a intensidade destas (energia ou afeto) corra livre e domine o sistema no sentido de descarga.

O que parece estar em jogo é da ordem do simbólico. O trabalho do processo psíquico secundário é fazer uma passagem da sensorialidade pura para uma condição de pensar; a partir de então, a mente teria a possibilidade de fazer representações, ou seja, vincular a energia e transformá-la. Permanecer menos tempo sob domínio dos processos primários, isto é, tolerar a tensão aumentada de estímulos e instituir a capacidade de pensar consiste em um trabalho árduo e Freud (1911-13/1996h) sugere que esse processo, em muitas pessoas, é difícil de alcançar. O autor adverte no trabalho "Formulações sobre os dois princípios do funcionamento mental" (FREUD, 1911-13/1996h) que a substituição do princípio do prazer (processo primário) pelo princípio da realidade (processo secundário) não acontece de repente e que esse seria o ponto fraco de nossa organização psíquica, uma vez que nos apegamos com devera tenacidade às fontes de prazer que estão à nossa disposição e tendemos a renunciar a elas com dificuldade.

Diante de um forte estímulo externo, o sofrimento mental provocado poderia mobilizar o oposto da condição acima mencionada (condição do pensar), liquidando 
com os processos secundários, como em um curto circuito. Haveria um domínio dos processos psíquicos primários e, consequentemente, fenômenos violentos de descarga, em relação aos quais o aparelho mental não teria recursos para intervir, como se ocorressem de maneira reflexa, condição tal para que a neurose traumática se desenvolva.

Laplanche (1998) menciona que, no caso de traumatismo, duas teorias são cabíveis, uma primeira que apresenta a noção de choque e uma segunda, a que atribui a importância do susto e do sentimento de ameaça vital, em detrimento do impacto externo sofrido. Freud cita que as duas teorias, embora opostas, não são irreconciliáveis, e que o elemento susto, pelo qual a psicanálise está particularmente interessada, seria condição para a neurose traumática, uma vez que assinalaria a falta de preparo do psiquismo para a ansiedade. A hipercatexia, nos sistemas que receberiam os estímulos somados à ansiedade, funcionaria como linhas de defesa do escudo protetor, na ausência deste, o aparelho mental ficaria à mercê dos estímulos.

Verifica-se uma mudança do pensamento freudiano à respeito da ansiedade como libido transformada, excitação acumulada que escapa sob forma transformada de ansiedade (FREUD, 1925-26/1996i), passando a considerá-la como um sinal de alarme, a partir da noção do ego como sede real da ansiedade.

A partir de então, a ansiedade é vista como uma reação a situações de perigo. Freud relaciona esses estados de ansiedade ao nascimento, momento em que a angústia é gerada (FREUD, 1925-26/1996i). Sempre que uma situação de perigo se repete, a angústia será reproduzida, ou seja, face a uma tensão excessiva, o ego ficará reduzido a um estado de desamparo. Essa sensação de ansiedade - tendo como sede o ego - revela a função específica de sinalização, pelo fato de que o ego é "governado por considerações de segurança" (FREUD, 1937-39/1996j, p. 213). Mediante seus recursos, tais como avaliação da realidade, pensamento, memória de experiências anteriores, a função do ego é realizar uma interpolação entre as exigências pulsionais e a ação que a satisfaz, com intuito de calcular as consequências da ação proposta e eventualmente viabilizá-la ou proibi-la. 
A ausência dessa angústia sinalizadora expõe o ego a perigos diversos decorrentes dessa falta de mediação egóica e essa seria a causa da neurose traumática. A causação associa-se ao fator surpresa, ao susto, ou seja, à entrada no perigo sem preparo. Laplanche (1998) adiciona que a neurose traumática é representada por uma brecha provocada por uma energia "externa" atacando uma vesícula não preparada (o aparato mental). Não havendo angústia, não há mobilização de energia na fronteira, inexistindo um contra-investimento que protegeria a "vesícula" do ataque. Nesse caso, o ego é invadido e submerso por uma grande quantidade de energia externa e, frente a essa inundação, suas funções ficam prejudicadas por meio do esforço para dar conta de todo o trabalho psíquico gerado. Diante desse contexto, estados de angústia são mobilizados, não para impedir o aparelho psíquico de ser invadido por grandes somas de excitação, mas sim para dominar e ligar psiquicamente as somas desmedidas de excitação, a fim de liquidá-las restabelecendo ao ego sua integridade.

Com o enfoque econômico em curso, a análise dos sonhos de indivíduos traumatizados e a observação de uma brincadeira de carretel de seu netinho de um ano e meio levam Freud a analisar que algo desprazeroso e desagradável, ao ser lembrado e repetido na mente compulsivamente, não está obedecendo exatamente ao princípio do prazer, ainda que esteja sob seu domínio, mas sim à outra força atuante. Observou que a brincadeira do seu netinho, de esconder e puxar o carretel ligado a um fio, ou seja, o aparecer e o desaparecer do carretel, "fort - da", reproduzia o aparecer e o desaparecer da mãe, uma tentativa de representar um conflito na mente da criança e uma busca de controlar sua angústia frente à ausência materna.

A brincadeira tinha o propósito definido de uma repetição de algo que a desagradou. O carretel que ela jogava, incansavelmente, aparecendo e retornando por meio das cortinas, encenava a inda e vinda de seus objetos, no caso, a ausência da mãe, com a qual a criança poderia lidar sem protestos. Como nesse caso, a repetição de algo desagradável não tem a ver com um prazer direto, mas sim com um prazer de outra ordem que também obedece à condição econômica de conter, reduzir ou eliminar as tensões a todo custo. 
A manifestação desta compulsão é acompanhada por um caráter altamente pulsional e retrógrado, em outros termos, que a pulsão tende sempre à restauração de um estado anterior de coisas (ou inanimado), o que dá margem a intensas discussões e a especulações acerca de uma força contrária àquela que impele ao desenvolvimento. Insere, desse modo, uma nova dualidade pulsional (anteriormente instintos do ego e instintos sexuais) na medida em que observa que, em todo organismo vivo, dois processos atuam em direções contrárias: um à vida, outro à morte. Tal contexto coloca a compulsão repetitiva a serviço da pulsão de morte, ou ao retorno ao que antes era ausência de um montante de estímulos excitatórios.

A compulsão à repetição está intimamente relacionada à neurose traumática. Sonhos, sintomas, transferência ou o próprio cotidiano, qualquer que seja o veículo da repetição da experiência traumática, representam as diversas tentativas de domínio das excitações. Esforçam-se por dominar o estímulo retrospectivamente, na tentativa de desenvolver a ansiedade, cuja omissão constituiu a causa da neurose traumática (FREUD, 1925-26/1996g).

Freud (1925-26/1996i) também estreita as relações de traumatismo com a perda do objeto. Ao referir-se à disposição das crianças de produzir ansiedade, observa:

Aqui a ansiedade aparece como uma reação à perda sentida do objeto e lembramo-nos de imediato do fato de que também a ansiedade de castração constitui o medo de sermos separados de um objeto altamente valioso, e de que a mais antiga ansiedade, a 'ansiedade primeva' do nascimento, ocorre por ocasião de uma separação da mãe (FREUD, 192526/1996i, p. 161).

A perda do objeto em questão (separação da mãe) para uma criança muito pequena está vinculada não apenas à ausência materna, mas também à não satisfação das necessidades. Uma crescente tensão, em razão da necessidade, pode levar a uma 
elevação da quantidade de estímulos desagradáveis, sem que esta possa ser dominada psiquicamente. A perturbação econômica precisa ser eliminada e a repetição da situação primeva de perigo faz com que a ansiedade se estabeleça.

A teoria freudiana propõe uma estreita relação entre neurose traumática e situações de perigo que resultam do desamparo psíquico sofrido pelo ego ainda imaturo na primeira infância (FREUD, 1925-26/1996i).

Freud sugere, no artigo "Inibição, Sintoma e Angústia" (1925-26/1996i), que quanto menor a criança, menor a sua capacidade de dominar psiquicamente uma somatória elevada de estímulos. Freud afirma, ainda nesse artigo, que a criança não está preparada para dominar elevadas somas de excitação (energia), quer fora, quer dentro de si e o perigo que o ego imaturo sofre corresponde ao desamparo psíquico. Os perigos inerentes ao desenvolvimento seriam a ameaça ou a perda de objeto até a primeira infância (período em que a criança é estritamente dependente de outros), o medo da castração até a fase fálica e o medo do superego no período de latência. Essas situações de perigo podem aparecer, lado a lado, em determinadas épocas do desenvolvimento ou entrar em ação todas ao mesmo tempo. Do ponto de vista de uma leitura freudiana, toda criança passa por essas situações de perigo com maior ou menor intensidade.

Ao final de sua obra (1937-39/1996j), Freud esclarece que experiências traumáticas, vividas no início da infância e depois esquecidas, podem acarretar danos precoces ao ego. Desse modo, dois destinos do traumatismo seriam possíveis: um positivo e organizador (mediante repetição, rememoração e elaboração) e outro, negativo e desorganizador (reações defensivas com enclaves no psiquismo).

Outros autores como Ferenczi (1932/2003) e Winnicott (1959/2000) contribuíram para as noções do trauma. Para Ferenczi, o trauma também está dividido em dois grandes grupos, os traumas que propiciam reorganização psíquica e contribuem para o desenvolvimento e os que o efeito surpresa somado à violência é desestruturante, mutilando o ego. Para tanto, afirma que um indivíduo inacabado só pode prosperar num meio ótimo, fazendo menção ao papel essencial que o externo ocupa na estruturação 
do indivíduo. Não entraremos em pormenores da teoria de Ferenczi (1933/1992), que tem muito a considerar a respeito da sedução e da confusão de línguas como propiciadores de estados de fragmentação do ego e que contribuiriam para a nãorepresentação. Além de Ferenczi, Winnicott (1896-71/1990) também foi um dos autores que privilegiou o acontecimento externo traumático como desestruturante para 0 psiquismo, especialmente nos primórdios do desenvolvimento.

Com as teorias desses autores como pano de fundo, gostaríamos de destacar a contribuição de César e Sara Botella (2002), autores contemporâneos, assim como de Ogden (2010), que desenvolveram o tema da neurose traumática bem como noções ligadas ao tema da não representação. Algumas idéias destes autores nos balizarão ao longo deste trabalho.

César e Sara Botella (2002) iniciam seu percurso relatando a situação de uma criança atendida por um deles; descreveremos, a seguir, pois também ilustra o que pretendemos discutir ao longo deste estudo.

Thomas é um menino de quatro anos, aterrorizado, que vai à análise após ter tido um início de vida marcado por hospitalizações e intervenções cirúrgicas (até os vinte meses sua artéria subclavicular estava mal posicionada, ele se sufocava e respirava mal, além de uma má-formação na uretra). Descrito pelos pais como tendo traços autísticos, os analistas o descrevem como alguém que nunca perdeu seu interesse pelo objeto. A sessão descrita é marcada por elementos sensoriais: apoderase de um tubo de cola o qual cheira com entusiasmo, procura raios de sol que recebe com olhos abertos, interessa-se pela reprodução de sons e de barulho. Thomas é uma criança de poucas capacidades elaborativas, dotado de um sistema de representação muito precário que sinaliza sua pára-excitação rompida e imediatamente seu estado de desamparo.

É evidente, por meio da descrição dos autores, que Thomas é um garoto que convive com o traumático. Uma vivência será experimentada como traumática no momento em que o sistema de representações não consegue captá-la, dar sentido a 
ela ou a tornar simbólica. Essa vivência, quando não transformada, torna-se excesso de energia causando uma fratura, um vazio na trama de representações.

César e Sara Botella (2002) evidenciam que a desorganização brutal desvelada pelo trauma não está em uma percepção de conteúdo traumático, mas na ausência de sentido do violento excesso de excitação e do desamparo do ego. O caráter traumático, dizem os autores, "não pode vir de nenhum conteúdo representável em si" (p.93), e sim da perda de recursos por parte do ego que rompe a coerência psíquica e acarreta desmoronamento dos processos primários e secundários; uma percepção sem participação sensorial, inconsciente, fora de representações, "além da representação" (p.91).

Não será a ausência do objeto que representará o perigo para o ego, mas sim, a sua não-representação marcada por uma ruptura que se torna excedente de energia. $O$ esgotamento do investimento da representação do objeto seria equivalente à perda da auto-representação, diante dessa percepção, vivida como estranha e má, o psiquismo sofreria, em sua globalidade, o afeto desenfreado de um "desamparo não-pensável e não figurável" em forma de "terror irrepresentável" (BOTELLA e BOTELLA, 2002, p.73).

Nesse contexto, o essencial do trauma infantil reside em uma negatividade: a não-representação por sua terminologia negativa significa uma 'zona' de nãorepresentação no seio do psiquismo que se caracteriza não somente pela nãorepresentação como também por uma ausência de sensorialidade. Por tal condição, apóia-se na noção do "trabalho do negativo" de André Green (2008), cujo conceito implica a existência de algo mais do que a ausência, uma presença não-presente, um registro apresentado pelo elemento psíquico inexistente, uma qualidade psíquica que se registra pelo negativo.

O aparecimento desse negativo se relaciona a uma ausência de conteúdo na percepção e não a uma percepção de conteúdo traumático seguindo o modelo de um "nem dentro nem fora" (BOTELLA e BOTELLA, 2002, p.189). O modelo se contrapõe ao "somente dentro também fora", fazendo menção a Freud, em que uma formulação da prova da realidade se dá por meio de uma articulação entre o psiquismo e o mundo 
externo: um duplo investimento interno e externo, por meio da representação do objeto e da sua percepção, respectivamente. Os autores consideram que

[...] Quando a percepção, de um modo totalmente inesperado, fracassa brutalmente diante da ausência de investimento do sujeito pelo objeto investido - é o próprio sentido de qualquer acidente na vida de uma criança - a relação entre a percepção alucinatória endopsíquica das representações e aquela dos órgãos do sentido se desfaz, o espelho interior se quebra. É a ruptura da simetria representação-percepção. Sem dualidade, sem conteúdo, o pulsional se desdobra livremente marcando o psiquismo com traços negativos, vazios de conteúdo. Porém, se, no lugar desse negativo, um conteúdo perceptivo consegue se impor ao ego, através da percepção dos órgãos dos sentidos, sem que este possa acionar o sinal de angústia, as condições estão então reunidas para que uma neurose traumática ocorra, para que o fenômeno de repetição alucinatória do conteúdo perceptivo se instaure. Caso contrário, se é a percepção endopsíquica das representações que impõe sua força, uma deformação da realidade que pode ir da recusa à sua reconstrução delirante torna-se possível [...] (BOTELLA E BOTELLA, 2002, p.190).

A simetria percepção-representação garante a coerência psíquica. É quem mede e limita a experiência de percepção fazendo uma correlação constante com o sistema finito de representações de palavras e coisas do psiquismo e que assegura o surgimento de novas representações mediante o pólo perceptivo. Na sua ausência, o ser humano confronta-se com o abismo do irrepresentável, da falta do objeto satisfação.

Diante do panorama de uma percepção violenta, o ego, na falta das ligações psíquicas superinveste, uma percepção na neurose traumática, "apodera-se desse mínimo de inteligibilidade" (p.106). Esse superinvestimento é uma primeira ligação antitraumática, como um início de elaboração, ao invés de determinações simbólicas que levariam a alguma representabilidade. 
A hipótese por eles sustentada é a de que a neurose traumática seria da ordem de um potencial em todas as estruturas, inclusive nas mais bem mentalizadas, isto é, contrária à noção de um fracasso ou produto de uma disfunção do psiquismo. Acreditam que a incapacidade do ego de fornecer figurabilidade às representações de coisas na neurose traumática não reside em uma percepção que é de qualidade traumática, mas sim no investimento desta (percepção) e na sua repetição alucinatória que já são reações defensivas do psiquismo diante do trauma.

Convém ressaltar que a desorganização psíquica não está na percepção, mas na ausência de sentido do violento excesso de excitação e do desamparo do ego, na impossibilidade de representá-los para si. Nessa concepção de neurose traumática, o ego não sofre passivamente, pelo contrário, participa do processo utilizando-se de uma "percepção-signo" na tentativa de criar um elo de causalidade que forneça uma explicação para o desamparo sofrido, pode ser "a imagem de uma percepção visual, mas pode muito bem ser uma percepção auditiva - por exemplo, o barulho do choque dos carros se a pessoa estava dormindo no momento do acidente" (p. 166). Essa via de acesso à "memória sensorial" permite ao ego restabelecer a coerência psíquica mediante tentativas de ligação. A esse respeito, os autores revelam que

Existe no psiquismo um princípio de convergência-coerência cuja função é de organizar um sentido, de ligar, sem verdadeiramente se preocupar com o sentido produzido-criado, de tal forma que é vital para a sobrevivência psíquica estabelecer ligações (BOTELLA e BOTELLA, 2002, p.21).

Sem essa condição, o psiquismo estaria fadado a ficar em seu estado primitivo, sem possibilidades de evoluir, devido a uma potencialidade traumática na própria natureza da atividade psíquica. Essa potencialidade pode ser melhor entendida em termos da primeira tópica, um núcleo traumático sentido como desamparo na origem da atividade psíquica que deve ser resolvido pela saída alucinatória. E, em termos da segunda tópica, a potencialidade traumática se constitui sob a exigência de elaborar 0 
caos pulsional que é o id. A potencialidade traumática existe em toda atividade psíquica, todavia, juntamente dela também existe uma forte tendência atuando no psiquismo em busca de crescimento e complexização.

Segundo os Botella, esse princípio (coerência-convergência) é comparável ao trabalho de figurabilidade do sonho, pois reúne elementos díspares, com intuito de manter a continuidade da vida psíquica. Sobre tal princípio, os autores escrevem que

[...] O ego seria submetido a uma pressão que agiria sobre as diferentes formações que compõe a vida psíquica, assim como sobre suas dinâmicas respectivas, obrigando-as a se unirem em um movimento de convergência e de coerência de um sentido global, sem a qual o psiquismo poderia ser arrastado, a cada instante, sob efeito da abertura do pólo respectivo, para o trauma da perda de seus limites. A simetria percepção-representação... representa uma modalidade dessa pressão. Por isso o valor de elo de causalidade da neurose traumática já é disso uma manifestação [...] (BOTELLA e BOTELLA, 2002, p.172).

Entende-se que um acontecimento real é traumático quando um movimento regressivo entra em ressonância com a potencialidade traumática por uma via sensorial direta quebrando os sistemas de representações em suas capacidades de ligação. $\mathrm{Na}$ falta de um outro meio de representação, uma via sensorial é acessada como meio de o ego restabelecer a coerência psíquica criando um elo de causalidade ou um elo de ligação, comparável ao trabalho de figurabilidade do sonho que reúne elementos díspares a fim de manter a continuidade psíquica.

Ogden (2010), outro autor que, sob uma vertente bioniana, discute a questão do traumático e da representação, considera o sonho como a possibilidade da mente sadia gerir a tensão ocasionada pelos estímulos. 
O sonho, para Ogden (2010), é um processo constante, que acontece na vida em vigília e no sono, mas que pode ser abalado, ou seja, a pessoa pode, em algum momento da vida, ter uma inibição no seu processo de sonhar. Seguindo uma linha bioniana, a capacidade de sonhar é vinculada diretamente à "função alfa" ${ }^{4}$ - funções mentais que juntas transformam experiências sensoriais brutas -. Essas experiências sensoriais brutas, sem nome, seriam denominadas de "elementos beta", impressões sem sentido, desprovidas de significado. Estes elementos não podem ser ligados entre si e não se transformam, não sendo usados para o pensamento ou para o sonho. $\mathrm{Na}$ contramão desses elementos, estariam os elementos alfa, estes, por sua vez, são elementos da experiência que podem ser ligados entre si, são impressões visuais, olfativas, auditivas armazenadas na memória, disponíveis para serem utilizadas para pensar e sonhar. Elementos alfa são produtos da função alfa, atuando juntas tornam a experiência emocional compreensível e com significado.

Todavia, o autor relata que "se uma pessoa é incapaz de transformar impressões sensórias brutas em elementos inconscientes da experiência que possam ser ligados, ela é incapaz de gerar pensamentos-sonho inconscientes" (OGDEN, 2010, p.19). O autor relata que, nesse contexto, a pessoa é incapaz de sonhar, tanto no sono quanto na vida em vigília inconsciente.

Dessa maneira, a mente pode tanto ter sucesso quanto fracassar. Por intermédio da metáfora dos distúrbios do sono, a nosso ver, o autor passeia pelas questões do traumático, das representações e do que foge à capacidade de representação. Ogden (2010) propõe que o funcionamento mental seja pensado em duas amplas categorias: a dos pesadelos e dos terrores noturnos. Pacientes que sofrem de terrores noturnos procuram ajuda para sonharem a experiência insonhável ou irrepresentável. Os sonhos sofrem um impedimento psíquico ou são próximos a um fenômeno psicótico. Estariam entre eles, pacientes psicossomáticos e perversos graves, de acordo com M'Uzan, os que sofrem encapsulamento autistico, seguindo a leitura de Tustin, pacientes que McDougall referiu como des-afetados, um tipo operatório de funcionamento mental e o estado esquizofrênico de "não experiência", que o próprio Ogden, em texto anterior,

\footnotetext{
${ }^{4}$ Termo cunhado por Bion (1962)
} 
atribui como pacientes que atacam sua própria condição de atribuir significado às experiências. Acreditamos incluir nessa categoria, pacientes vítimas de traumas graves em que a ação do trauma é negativa e desorganizadora.

Pacientes que sofrem pesadelos metafóricos são aqueles que necessitam de outra mente para ajudá-los a sonhar. Esses pacientes sofrem de sonhos tão ruins e assustadores que o despertar interrompe sua elaboração psicológica, uma vez que a mente não dá conta de sonhá-los sozinho (OGDEN, 2010). Podemos encaixar nessa ampla categoria os pacientes que sofrem situações traumáticas. Nessa linha de pensamento, o excesso de estímulos, como nos é dado por meio da concepção freudiana, dificulta e, muitas vezes, inibe o sonhar, assim como impede as capacidades de representar a experiência vivida, a função alfa falha e o sonho é interrompido (OGDEN, 2010).

Nesse contexto, apoiados nas idéias de Botella e Botella (2002), e tendo como pano de fundo as contribuições de Ogden (2010), estamos de acordo que o trauma infantil não responde ao modelo do a posteriori (concepção de trauma como fato passado que se manifesta em um tempo posterior mediante um sintoma) e ao modelo do traumatismo de guerra (neurose traumática). Estes, em contrapartida, apesar de angustiantes, protegem o sujeito de uma paralisia motora e psíquica - estados que os traumatizados descrevem com frequência. O trauma segue sendo, para os autores, tudo o que não pode ser psiquicamente elaborado, ou seja, o que não entra na rede de investimentos e contra-investimentos, de representações e de conflitos, uma zona que ultrapassa as possibilidades de figuração, em que só se suspeita de sua existência por meio de uma não-representação, um não-sonho - um traço perceptivo marcado por ausência de inteligibilidade e sensorialização do fenômeno -.

Como no caso de Thomas, o que os autores propõem como estratégia clínica é, aos poucos, tornar inteligível aquilo que é, no momento, ininteligível e tentar dotar de símbolo e significado uma vivência desintegrada e desconexa. Na concepção de Ogden (2010), ajudá-lo a sonhar. 
Ao pensarmos em crianças que experimentaram um excesso, o qual entendemos como uma quantidade de estímulos além do que o psiquismo possa suportar, inferimos que foi exposta a um (ou mais) eventos de natureza traumática. Seguindo o que propõe os Botella, podemos pensar que a neurose traumática não segue o modelo do trauma infantil proposto por Freud. Nesse contexto, uma criança que sofre de uma neurose traumática não significa que sofre de um trauma. A neurose traumática também remete aos aspectos econômicos do psiquismo (uma vez que se trata de um excesso), no entanto, já seria uma tentativa anti-traumática - o psiquismo está em um esgotante trabalho para lidar com o excesso.

Não é possível saber se uma criança vítima desse excesso, como no caso de uma enfermidade grave, com necessidade de hospitalização e operações de grande porte, sofrerá exatamente de uma neurose traumática ou de um trauma por ter sido submetida, por um período de tempo, a constantes intervenções. Outras muitas questões fazem parte desse exame cuidadoso e, ainda sim, podem escapar a nosso entendimento. Nesse sentido, o traumático poderá designar tanto uma potencialidade traumática na base de todo funcionamento psíquico e, portanto, participar da gênese, da organização, da pulsionalidade, do desejo, quanto designar a disfunção do psiquismo frente a um acontecimento de força desorganizadora. Bokanowski (2005) propõe que os níveis em que operam a ação do traumático sejam distinguidos, uma vez que as desorganizações geradas pertencem a naturezas diferentes. De acordo com esse pensamento, o termo 'traumatismo' seria, especificamente, designado a um tipo de organização que dirige o funcionamento psiconeurótico e fundamentalmente regido pelo après-coup (a posteriorı); o termo 'traumático' seria usado para designar um aspecto mais econômico relacionado a uma brecha na pára-excitação, como descrita por Freud em "Além do Princípio do Prazer"; e ao termo 'trauma' estaria reservado, mais especificamente, a ação negativa e desorganizadora da situação traumática, tal qual concebe o casal Botella.

É útil ressaltar que não poderemos inferir exatamente qual a repercussão e os exatos desdobramentos de um evento potencialmente grave no psiquismo infantil. Sabemos que se trata de uma situação, sim, potencialmente traumática, no entanto 
como a criança irá reagir a tal situação dependerá de sua história prévia, de sua organização psíquica (devido à existência também de uma potencialidade traumática no seio de todo psiquismo) e de o ambiente ser mais ou menos continente com as angústias suscitadas pela experiência. Contudo, o próprio caráter traumático da experiência anuncia que essas crianças precisam tolerar um quantum de excitação que, muitas vezes, extrapolam seu aparelho mental.

Como entender e ajudar crianças vítimas desse tipo de violência paradoxal: traumática e, ao mesmo tempo, salvaguardora de suas vidas? Como é possível suportar? Como é possível a criança sofrer riscos, beirar os limites da vida, sentir a violência no corpo, desprover-se dos objetos que Ihe dão identidade, suspender-lhe o tempo, ter sua infância corrompida e ainda progredir? Manter seu aparelho psíquico íntegro e capaz de se desenvolver? Ser capaz de sofrer as vicissitudes de sua existência e ainda se apropriar de recursos para manter-se viva?

\subsubsection{A Criança sob Terreno Árido: Vicissitudes do Traumático}

Para a equipe hospitalar que acolhe a criança, doente grave, o corpo é alvo de urgência. Para a criança enferma, não há alternativa a não ser renunciar seu desejo em favor de um outro. Adoecer, enfermar, mortificar, sinônimos em que está contido o desamparo do indivíduo que se submete ao enunciado da medicina para poder existir.

Nessa interface da medicina com a psicanálise, a criança que vivencia uma doença grave tem sua subjetividade, momentaneamente, dilacerada: medo, frustrações, falta de autonomia convivem face a face com a dor física, manipulações, procedimentos invasivos em um corpo que é usado e abusado. Essa forma de violência engendrada no corpo, ao mesmo tempo em que é inevitável, salvaguarda a vida.

Para além do momento de estresse agudo provocado pela necessidade de uma operação, de uma internação em unidade de cuidados intensivos, dias de afastamento 
de sua rotina diária, subsiste, muitas vezes, uma condição crônica que pode ser debilitante. Quando isso acorre, a criança pode ter seu desenvolvimento tanto físico quanto psicossocial prejudicado, dependendo da gravidade da condição.

Ainda hoje, apesar de inúmeras pesquisas referentes à necessidade, à importância e aos benefícios do cuidado emocional das crianças em ambiente hospitalar, não raro ocorre seu esquecimento, mesmo com as propostas de humanização do tratamento. Desse modo, as intervenções clínicas e operatórias trazem a esperança da vida concreta, mas a vida emocional, muitas vezes, carece ainda de atenção dentro do hospital geral.

Cabe-nos refletir sobre qual o sentido da experiência traumática na infância e sobre efeitos no aparelho psíquico de um ser que está em pleno desenvolvimento, sobretudo em termos de vitalidade mental. Isso porque é, no período da infância, que o aparelho psíquico se estrutura e se torna matriz de toda a trama subsequente. Isso significa que a criança tem, durante as primeiras etapas da vida, perigos inerentes à cada fase da vida seguidos de traumatismos fundantes que organizarão seu psiquismo de maneira mais favorável ou não, ou seja, de modos mais positivos ou mais negativos.

No caso da criança gravemente doente, ela tem reativado e potencializado, dentro de si, todos esses perigos no momento em que tem de haver com sua doença, isto é, diante das hospitalizações e operações absolutamente invasivas, tal como a ameaça de castração.

Que a hospitalização e operação são disparadores traumáticos isso é fato. Em trabalho anterior (AMARO DA SILVA, 2006), pudemos fazer essa verificação por meio de uma varredura da literatura a respeito de vários trabalhos que associavam uma doença ou uma condição médica geral ao chamado transtorno de estresse póstraumático. O enfoque psicanalítico frente a essas condições também foi objeto de estudo, entre outras circunstâncias, os artigos apontavam a ameaça de fragmentação em um ego, ainda frágil, da primeira infância e a importância do ambiente como contentor ou disparador de maiores fontes de angústia, como a família e a equipe de cuidados da criança gravemente doente. 
Cremos que a situação traumática reverberará em cada criança, diferentemente, e dependerá dos alicerces de seu psiquismo. Em outros termos, sabemos do montante de estímulos disparados pela situação da hospitalização, mas a criança poderá reagir de forma mais positiva, com possíveis elaborações, ou mais desorganizadora, evidenciando e re-significando conflitos preexistentes.

Com relação a este último aspecto, de maneira geral, podemos inferir perturbações no processo de simbolização, tal qual nos sugere Ogden (2010) ao mencionar os pesadelos e as dificuldades no processo de sonhar e também, em casos mais extremados, pacientes que sofrem de terrores noturnos metafóricos, incluindo toda a gama de somatizações, patologias do vazio, para citar alguns, como anteriormente mencionado.

A doença, a hospitalização e a internação, em unidade de terapia intensiva, são experiências capazes de evocar estados afetivos de natureza traumática e caótica. Dependendo da suscetibilidade da criança afetada pode trazer consequências nocivas para o aparelho psíquico, especialmente se este for pobre de recursos. Isso significa que também dependerá das primeiras inscrições, da capacidade de representar as experiências, como fora dito na primeira parte desta discussão, ou seja, da condição mental de cada criança.

Nesse sentido, de quais meios nós poderíamos dispor para que a situação potencialmente traumática não desencadeie um trauma na vida da criança? No caso exemplificado pelo casal Botella (2002), o quanto é possível fazer por uma criança como Thomas que viveu experiência de qualidades traumáticas?

\subsection{EM BUSCA DE UM TERRENO FÉRTIL... A MOVIMENTAÇÃO PSÍQUICA E AS TENTATIVAS DE ELABORAÇÃO}


A condição que acabamos de descrever nos coloca face a situações que pertencem à ordem do simbólico. Talvez, pudéssemos não descartar que, vez ou outra, adentramos no campo das neuroses, mas sobre esse ponto retornaremos quando nos parecer oportuno. O que queremos destacar e privilegiar é muito mais o campo do traumático, que coloca em foco o aspecto econômico dos estímulos suscitados pela experiência, do que o traumatismo que, regido pelo à posteriori, resulta no funcionamento psiconeurótico.

Estamos, portanto, diante do terreno árido do traumático que desencadeia a problemática dos estímulos. Discorreremos, nesse tópico, sobre a busca de movimentações que propiciem a fertilização desse terreno, por meio das tentativas de elaboração. Esperamos, ao final, responder alguns questionamentos levantados e que se referem aos recursos que podemos dispor para ajudar os pequenos pacientes que vivenciam situações traumáticas.

Queremos posicionar aqui que a base de toda a nossa construção teórica, desde o início desta pesquisa tem sido, evidentemente, a freudiana. Ressaltamos que o que nos motiva nos reportar a Freud é partir da base fundante da psicanálise. Todavia, os avanços teóricos serão acrescidos por outras vertentes de pensamento que estruturam a nossa linguagem e pautam nosso trabalho e que, sob certo ponto de vista, são acréscimos e evoluções à teoria de Freud.

Freud (1925-26/1996g) escreveu que a possibilidade de a mente suportar uma experiência de tensão sem ser avassalada por conteúdos traumáticos está relacionada à capacidade do aparelho psíquico de vincular em pensamento as experiências vividas. Fazer com que a mente possa operar em um modo de funcionamento secundário (vide os processos secundários), a fim de vincular os afetos a representações e, desse modo, transformar a representação coisa em representação palavra, ou ainda, uma experiência ininteligível em conteúdo simbólico; entendimento este também corroborado pelos Botella (2002). Freud via a possibilidade de pensamento como um recurso para reduzir a tensão ocasionada pelos estímulos, de maneira que tanto a frustração quanto o sofrimento seriam removidos. 
Também estamos aqui pautados na teoria de Antonino Ferro que segue, em muito, as contribuições bionianas e, desse modo, privilegiará o trabalho de transformações. Isso significa que, diante da questão do excesso de estímulos, a mente precisa transformar elementos sem sentido em algo simbólico. O pensamento seria um recurso para gerir, e não reduzir (como na teoria freudiana), a tensão ocasionada pelo excesso de excitação. Dessa maneira, seria como desenvolver a capacidade de tolerar a dor psíquica e não de eliminá-la.

A respeito do trabalho da mente em busca de inteligibilidade, Ferro (2005) dirá que é necessária uma aparelhagem adequada que possa "transformar os inputs recebidos em experiências pensáveis" (FERRO, 2005, p.160), ou seja, uma mente capaz de absorver e elaborar a quantidade de estímulos a que está exposta diariamente. Para Ferro, o traumático residirá em "cotas de sensorialidade e protoemoções que uma experiência causa e a capacidade/incapacidade da aparelhagem adequada (...)" (FERRO, 2005, p.160), isto é, de uma mente adequada para simbolizar a experiência vivida. Desse modo, as vivências traumáticas seriam como protoemoções e proto-sensações puras, em outros termos, elementos beta ${ }^{5}$ que necessitam ser transformados em elementos alfa, isto é, em elementos protovisuais.

Nem sempre a mente tem condições para reduzir ou mesmo gerir os recursos. Aliás, é nesse ponto que o traumático se faz presente, dificultando a simbolização e os processos que levam ao pensamento, ou seja, comprometendo o trabalho da função alfa. Muitas vezes, o indivíduo e, nesse caso, a criança precisa de outra mente disponível para que possa ajudá-la nesse trabalho de transformar o pesadelo (OGDEN 2010) em um sonho bom.

O estado traumático presente no caso de Thomas (BOTELLA e BOTELLA, 2002) é visível a partir de estados de fragmentação, aos quais referem o casal Botella.

\footnotetext{
${ }^{5}$ Como já mencionado, esses 'elementos' [beta e alfa] são termos empregados por Bion (1963) para designar múltiplas formas de arranjos entre si que codificam a experiência mental. Elementos beta são experiências mentais e impressões sensoriais puras, brutas, são coisas em si mesmo, não se prestam ao pensamento e sim, somente, a evacuações. Em contrapartida, elementos alfa são experiências emocionais e impressões sensoriais transformadas em imagens visuais, são usadas pela mente a serviço da simbolização e do pensamento.
} 
Segundo estes autores, o trabalho do analista envolve uma construção sob formas figuradas em que os elementos, sem qualidade de representação psíquica, podem tornar-se lembranças. No caso de Thomas, a retomada dos elementos - cheiro, luz, barulho, pelo analista - reconstrói uma lembrança para a criança, dando a ela o sentimento de existir, ainda que não se saiba se estes elementos sensoriais são condutas autísticas ou, de fato, pedaços dispersos de realidade material suscitados pela experiência de hospitalização. Conjecturamos, ainda, se os traços autísticos de Thomas não puderam ser ativados ou reativados diante das duras experiências precoces causando feridas no ego.

Botella e Botella (2002) descrevem que, na mesma sessão com esta criança, próximo ao término dela, frente a uma situação difícil suscitada por angústias de separação, a analista figura, em um flash, a imagem de um lobo e pergunta à criança: “Crra...crra! Você tem medo do lobo?". O 'lobo' figurado pela analista permite um esboço de representação no mundo interno da criança, tal como a narrativa dos contos, em que as representações veiculadas despertam a figuração da criança.

Pensamos o quanto a figuração 'você tem medo do lobo?' oferecida pela analista pode favorecer a transformação dos elementos psíquicos na mente da criança, de elementos beta para elementos alfa. Relembrando, esses elementos alfa são predominantemente imagens visuais, ou proto-imagens, que ainda não adquiriram a qualidade de um pensamento, mas sim um início de transformação do contingente pulsional que pressionava e constituía uma primeira forma de representação da experiência emocional. São como proto-idéias, uma emoção que adquire uma qualidade de pensabilidade sem, contudo, constituir-se em pensamento. Posteriormente é que serão utilizados pela mente para a formação dos sonhos, para simbolização e para o pensamento.

Concordamos com César e Sara Botella (2002) quando mencionam que, mediante uma intervenção, podem preencher uma beância aberta provocada pelo traumatismo, assim como pedaços soltos de realidade material podem ser reestabelecidos em uma coerência psíquica, ainda que sutilmente, por meio de novas 
ligações. Aos poucos, a criança sente que pode existir como unidade sem se sentir fragmentada.

Entendemos que a fala do analista, no momento em que traz uma imagem associada à experiência trazida pelo paciente, tem um efeito metabolizador das angústias da criança, uma vez que segue um modelo semelhante ao que se opera na relação afetivo-emocional da criança com a mãe. Esse modelo se estende à relação entre paciente-analista, mediante as operações de rêverie.

O termo rêverie designa uma capacidade da mãe (rêverie materna) de favorecer o desenvolvimento da criança por meio de um jogo de projeções e introjeções. Angústias e sensorialidades primitivas da criança são projetadas (por identificação projetiva) na mente da mãe, que as recebe, acolhe e as transforma; em outros termos, essas projeções são "tratadas e bonificadas" (FERRO, 2005, p.29) pela mãe e, novamente, devolvidas à criança. A operação de rêverie é possível por intermédio da função alfa ${ }^{6}$ da mãe que transforma os elementos betas da criança sendo capaz de, aos poucos, favorecer o desenvolvimento de uma função alfa operante na mente da criança. Esta forma primitiva de comunicação mãe-bebê seria primordial para auxiliar o desenvolvimento da capacidade da criança de lidar com as experiências emocionais, desenvolver sua capacidade de lidar com a frustração, desenvolver o pensamento como forma de lidar com as angústias e importante instrumento de compreensão e trabalho psicanalítico.

Acreditamos na hipótese de que, diante de crianças expostas a situações extremamente difíceis, o analista pode funcionar como um decodificador das angústias do pequeno paciente, metabolizando e favorecendo a transformação dos elementos beta em elementos alfa, a partir de uma função alfa, através de operações de rêverie. Nesse contexto, algo que deve ser construído na relação através de uma tonalidade afetiva do par analista-paciente (FERRO, 1995) promoveria a condição de simbolizar e, portanto, atingir a possibilidade de pensar.

\footnotetext{
${ }^{6}$ Da função alfa resultaria a possibilidade do indivíduo pensar e simbolizar
} 
Como já fora visto, a situação traumática afeta sobremaneira o processo de formação de símbolos e, consequentemente, os processos de pensamentos (SEGAL, 1991).

Símbolos representam e exprimem emoções por meio de imagens visuais. As experiências emocionais são significadas de acordo com a capacidade individual de transformar e de criar símbolos. A apreensão e transformação dos significados em elementos expressivos se darão com base na representação por imagens pictóricofigurativas (BARROS, 2007). A essas representações das experiências emocionais Barros (2000) chama de pictograma afetivo, um primeiro passo em direção aos processos de pensamento. Pictogramas afetivos são não-discursivos, muito embora contenham elementos expressivos-evocativos como na fala, 'você tem medo do lobo?' (narrada pelo casal Botella), a frase tem o poder evocativo tanto da imagemrepresentação quanto de uma expressividade. De acordo com tal premissa, ao analisar o trabalho dos Botella (2002), Barros (2007) argumenta que a imagem do lobo exprime a captação de significados conscientes e inconscientes do par que está em relação (no caso, analista e paciente) e propõe uma dupla especificidade do símbolo, representar e expressar que articula-se com o trabalho psíquico de elaboração.

Símbolo e processo de elaboração estão intimamente relacionados, não há elaboração psíquica sem o trabalho de simbolização. César e Sara Botella (2002) utilizam a imagem do lobo valendo-se do conto como parte da construção simbólica, uma vez que enriquece a vida mental da criança ativando suas redes simbólicas. Ao pensar na figuração do 'lobo', os autores dizem que

[...] O dinamismo desse tipo de intervenção é comparável àquele exercido pela narrativa dos contos em que, num contexto terno, o adulto evoca representações muito carregadas de pulsionalidade, situadas num além e num passado de uma história coerente e 'verdadeira', pois revogável à vontade. As representações assim veiculadas despertam a figuração da criança e diminuem a pressão desorganizadora do contingente pulsional pré-representado. $\mathrm{Na}$ comunicação entre a criança e o adulto, o conto 
constitui uma verdadeira ponte, conduzindo a vivência não organizada, dificilmente representável para a criança numa relação com seus objetos reais, na direção do universo maravilhoso da representação (BOTELLA e BOTELLA, 2002, p.31).

O conto tem a possibilidade de fazer uma vinculação, de transformar em representabilidade algo não pensado, de fazer a passagem entre a representação coisa para representação palavra (Freud, 1914-15/1996c), ou ainda, transformar elementos beta do paciente em elementos alfa, assumindo-os, digerindo-os e os narrando com intuito de possibilitar a passagem para o simbólico, mediante novas aberturas de sentido (FERRO, 2002). Ferro (2002) discorre amplamente sobre essas idéias revelando a singularidade dos contos infantis:

[...] Creio que a preciosidade dos contos para o desenvolvimento mental de uma criança esteja substancialmente em dois pontos: a sua insaturabilidade, isto é, o fato de que cada criança possa preencher qualquer conto, em momentos diferentes do próprio crescimento, ou até mesmo, momentos diferentes de próprios estados emocionais, com significados diferentes, além disso, a trama afetiva que se estabelece com o narrador, porque não é no texto narrado, mas na espessura afetiva e emocional que se cria com quem conta e 'vive' e se ativa aquele algo de transformador das mais profundas fantasias da criança [...] (FERRO, 2002, p.77 apud FERRO, 1985).

Estes dois aspectos centrais revelam o quanto o conto pode favorecer 0 desenvolvimento das capacidades simbólicas e elaborativas da criança. No primeiro aspecto, a possibilidade de o conto representar e expressar sentimentos, medos, emoções ao se identificar com os personagens e, no segundo aspecto, o conto pode conter, devido ao fato de que por meio dele é possível encontrar soluções para as mais temidas situações, criando a capacidade de conter tais sentimentos, emoções e medos 
(FERRO, 2002). É importante salientar que, para este autor, a insaturabilidade é uma chave mestra e, nesse caso, indica que o conto não é estático, não é fechado, e não é uma representação completa das angústias infantis, mas sim, uma "proposta de simbolização que poderá ser utilizada por cada criança" (FERRO, 2002, p.79) como no sonho (OGDEN, 2010).

O sonho tem um potencial gerador de representabilidade e expressividade visto que é dotado de recursos capazes de reunir em imagens os afetos e as emoções ainda sem possibilidades de serem pensadas (FERRO, 1995).

O inverso do pensamento acontece nas situações potencialmente traumáticas, o sujeito fica impedido de narrar a sua história, as associações paralisam e congelam, o significado se esvazia. Propiciar o não congelamento, a não paralisação e dotar de significado seria também favorecer o paciente a narrar um conto e sonhar. No caso da criança que vive experiências de qualidades traumáticas poder viver um sonho a dois (paciente e terapeuta), é também fazer a criança passar de um estado de não brincar a brincar.

\subsubsection{O Brincar - Propiciador de Movimentação Psíquica}

Freud foi, sem duvida, quem lançou um dos primeiros olhares para as questões infantis relatando um brincar nada ingênuo de uma criança - esse brincar, pelo contrário, era revelador de muitos significados. O jogo do carretel ilustra classicamente o quanto Freud interessou-se pelo brincar na tentativa de abarcar, tanto quanto estava ao seu alcance, o funcionamento mental. Ao observar a brincadeira de uma criança, seu netinho, constatou que o brincar - esconder e puxar o carretel ligado a um fio, ou seja, o aparecer e o desaparecer do carretel "fort - da" - reproduzia o aparecer e desaparecer da mãe, uma tentativa de representar um conflito na mente da criança e tentativa de controlar sua angústia frente à ausência materna. 
Contudo, foi com Melaine Klein que a análise de criança sofreu uma reviravolta. Por volta de 1920, Klein (1926/1996) introduziu o jogo como uma técnica psicanalítica infantil. Importante salientar que se foi Freud quem declarou que os caminhos para o acesso ao inconsciente eram os sonhos, Klein atualiza o brinquedo como uma via para o inconsciente da criança. Na mesma época em que M. Klein tentou sistematizar as primeiras técnicas de atendimento de crianças por meio do brincar, Anna Freud propôs suas idéias a respeito de análise de crianças criando-se, assim, dentro da psicanálise, duas correntes opostas; dentre as divergências suscitadas a possibilidade de valer-se do jogo como equivalente da associação livre, ao contrário do caráter pedagógico que propunha Anna Freud. Subsequentemente, por ocorrência da Segunda Guerra Mundial, D. Winnicott, mediante seu contato muito próximo com as crianças e as observando, interessou-se pela psicanálise infantil. Em meados de 1945, após debates e controvérsias, três grupos dentro da psicanálise haviam sido formados: os freudianos, dirigidos por Anna Freud, os kleinianos e o Middle Group coordenado por Winnicott, que se manteve distante durante as polêmicas suscitadas por Klein e Anna Freud.

Diversas ramificações e outras vertentes da psicanálise de crianças surgiram a partir destas correntes, como é possível observar na psicanálise contemporânea. Dentre as ricas contribuições do desenvolvimento da psicanálise infantil, ao longo do tempo, uma delas foi a ênfase na criação de um espaço que possibilitasse o brincar conjunto de analista e paciente. A contribuição de Winnicott foi para além das descobertas da época quando prioriza o estar junto da criança. Uma de suas contribuições mais notáveis está na conceitualização do "espaço potencial" (WINNICOTT, 1971/1975), um dos corolários de suas contribuições. A noção winnicottiana de espaço potencial propõe a existência de uma zona intermediária de vivências entre a realidade interna e externa, em que se tem origem todas as atividades sociais, criativas e culturais, nesse 'lugar' produz-se tanto o jogo, a criatividade quanto a psicoterapia e as vivências culturais.

O espaço potencial começa a ser criado na relação do bebê com a mãe, na medida em que o primeiro pode suportar a ausência do segundo. $O$ bebê precisa encontrar algo na realidade que possa aplacar essa ausência. Esse espaço ou área 
intermediária da experiência só é possível com a entrada no campo dos fenômenos e objetos transicionais, no qual esse 'espaço' pode ser 'preenchido'; para tal, contribuem tanto a realidade interna quanto a externa. Essa área intermediária é fundamental para que a criança, na tenra infância, possa estabelecer suas primeiras relações com um mundo. É dessa maneira que o objeto transicional é uma possessão da criança que se relaciona tanto com o objeto interno quanto com o externo, mas que difere deles. Nesse sentido, Winnicott discorre que

\footnotetext{
Essa área intermediária da experiência, incontestada quanto a pertencer à realidade interna ou externa (compartilhada), constitui a parte maior da experiência do bebê e, através da vida, é conservada na experimentação intensa que diz respeito às artes, à religião, ao viver imaginativo e ao trabalho científico criador (WINNICOTT, 1971/1975, p. 30).
}

Significa que essa área intermediária da experiência é possível na medida em que representa, para a criança pequenina, um estado de transição entre o que é fusionado com a mãe e algo que não é ela, algo externo e separado. Um movimento precede esse desenvolvimento e é fundamental para esse processo de maturação: a fusão do bebê com a mãe. Essa fusão permite a criação de um fenômeno ilusório, fundamental no processo do bebê de vir-a-ser, de que este poderá criar o mundo amparado pela mãe. Para tanto, os fenômenos e objetos transicionais pertencem ao domínio da ilusão, de que aquilo que o bebê cria existe realmente. Dessa etapa em diante, a criança vai construindo algo, e que permanece ao longo do desenvolvimento do indivíduo, que é a própria subjetividade, a partir de um confronto com o teste de realidade (desilusão).

Pode-se pensar que a vida é experimentada nesse espaço 'entre' a realidade interna do indivíduo e a realidade compartilhada, por meio dos fenômenos e objetos transicionais que têm por função assegurar a vida imaginativa do indivíduo ao mesmo tempo em que o adapta à realidade. Esse espaço intermediário "está em continuidade 
direta com o brincar da criança pequena que se 'perde' no brincar" (WINNICOTT, 1971/1975, p.29). O brincar localiza-se nesse 'lugar' potencial e sua expressão máxima é o viver criativo onde "se aprende a transformar e a usar os objetos do mundo, para nele realizar-se e inscrever os próprios gestos, sem perder o contato com a própria subjetividade" (PARENTE, s/d, p.25).

Posta assim a questão desse espaço potencial, encontramos uma outra vertente do brincar, em uma comunicação mais recente que nos é de grande valor. Ferro (1995) dirá que a questão de que a presença de um observador no campo analítico não tem como ser passiva de neutralidade. $O$ jogo, dentro do encontro psicanalítico, não é mais o jogo da criança, mas um jogo que pertence ao campo, ou seja, à dupla, em um vértice compartilhável de ambos (FERRO, 1995).

Nosso desejo é de assimilar a idéia de cada um destes autores e encontrar um campo de saber e desenvolvimento que nos permita entender, compartilhar e criar um espaço possível onde o encontro psicanalítico possa ter um caráter lúdico, onde paciente e terapeuta juntos naveguem por caminhos a serem desbravados. É preciso ressaltar que esse percurso só é possível na medida em que o terreno seja fértil o suficiente para permitir um encontro, ou, nas palavras de Ferro (1998), um setting adequado capaz de continência, elasticidade e possibilidade de transformações.

Partindo desse princípio, o jogo (ou brincar) para Ferro (1995, p.81) "é um meio utilizado pelas crianças para dramatizar, representar, comunicar, descarregar as próprias fantasias [...]”, mas que só será pleno transformador de angústias na presença mental de alguém que brinque com ela.

Verifica-se que, em sua teoria, o autor enfatiza um modelo de escuta e interpretação que difere (e soma) daquele sugerido por Freud (história de vida e experiências passadas) ou Klein (história intrapsíquica, fantasias e projeções). Propõe um modelo de escuta que chama de "relacional insaturado" (p.91) em que considera a história da criança e do analista juntos. Sendo assim, as construções de sentidos e significados serão do par, não mais projeções ou repetições da criança, mas a história da dupla é que será possibilitadora de transformações. A escuta atenta do analista é 
que permitirá acompanhar a criança na sessão e, assim, navegar junto dela pelos mares que ela os conduzir, ao invés de naufragar. As contribuições de Winnicott (1971/1975) vão ao encontro dessa proposta ao referir-se ao uso que o psicanalista faz do conteúdo da brincadeira interpretando maciçamente, ao invés de olhar para a criança que brinca e, avançando um pouco mais, brincar com ela.

A história da dupla, ou seja, a história compartilhada pelo terapeuta e paciente, mediante o brincar, constitui nosso principal foco de campo emocional. Isso porque, essa história, intimamente relacionada com a vivência da dupla, traz uma nova possibilidade de trabalho com o inconsciente que não depende tanto mais da memória (SOUZA, 2008a). Nesse sentido, Tanis (2008) e Souza (2008a) concordam que, diante dessa recente forma de trabalho com o paciente, as interpretações decodificadoras não reinam soberanas, mas dão lugar também às funções simbólicas que emergem na sessão, por meio da obtenção de sentidos. No seu mais recente trabalho, Ferro (2008) dirá que criatividade (essencialmente a reverie, a fantasia) e técnica (interpretação) oscilam dentro de um trabalho com o paciente, todavia, o autor acredita que a escolha interpretativa, por ser mais técnica é mais segura, mas "frequentemente menos fértil" (p.15) e que, em contrapartida, apesar da opção criativa estar mais sujeita aos devaneios subjetivos, pode também ampliar espaços e caminhar para rumos antes não pensados. Desse modo, no brincar com a criança

[...] O analista se tornará 'o lugar das histórias e dos jogos possíveis', prestando-se a todos os papéis emocionais pedidos pelas necessidades do campo, papéis que em seguida poderão ser restituídos à 'pensabilidade' e verbalização, após serem transformados no working-through do próprio analista (FERRO, 1995, p.81).

Nesse caso, o que queremos aqui expor é o contínuo trabalho do analista de poder oferecer um lugar em que a criança possa trazer suas angústias inominadas e transformá-las por meio do brincar conjunto (grifo nosso). Transformar o inominável em 
algo com 'pensabilidade' e maior capacidade de 'metabolização' é algo que pertence à ordem do simbólico, da construção de sentidos. Pitliuk (2008), seguindo as contribuições de Bleichmar (2005), menciona que a intervenção analítica é, efetivamente, capaz de produzir algo que não estava formado, para tanto, "traz/produz/favorece uma composição ou recomposição psíquica" (PITLIUK, 2008, p.267), dessa maneira, não só revela, mas, a partir de novas configurações, constrói. Voltamos a mencionar que, nesse sentido, o brincar é equivalente ao sonhar.

Alvarez (1994) evidencia que uma das questões que permanece em comum a todas as teorias analíticas é a crença no significado do brincar, independentemente de qual a brincadeira, mesmo que seja aparentemente a mais simples ou até mesmo a mais sem sentido. O brincar está intimamente relacionado à formação de símbolos, ou à condição de estabelecer representações e, da mesma maneira, a impossibilidade do brincar está relacionada a uma incapacidade de formação simbólica.

Klein (1946-1963/1991, p.165), a respeito do brincar como manifestação simbólica, refere que

[...] o bloco, a figurinha, o carro não representam apenas coisas que interessam às crianças por si mesmas: no seu brincar elas têm também uma variedade de significados simbólicos que estão interligados com as fantasia, desejos e experiências da criança.

No mesmo texto, ainda, Klein considera que a criança garante um quantum de alívio no brincar, pois é possível que, além de fantasias, a criança também transfira a outros objetos (brinquedos), e não só a pessoas, ansiedades e culpa. Nesse sentido, Winnicott (1971/1975) também propõe que no brincar a criança lida com fenômenos e objetos externos a serviço do sonho e os tece de inúmeros significados. Nestes casos, o brinquedo ou um objeto externo qualquer funciona como um disparador, despertando a realidade interna da criança ou, nas palavras de Ferro (1995, p.80), "o brinquedo se 
coloca como um pré-texto de uma narração que se desenvolverá no jogo". O brincar como recurso simbólico oferece a possibilidade de representação, de transformação do vivido passivamente em ativo, do domínio da realidade, de repetição do traumático em busca de elaboração e também da busca do novo e da criatividade (SOUZA, 2008b) no qual a criança vai se curando por si mesma (RODULFO, 1990).

Deve-se notar que os símbolos viabilizam o intercâmbio tanto do mundo exterior (uma vez que governam a capacidade de comunicação) quanto do mundo interior. Segal (1991), em um aprofundamento sobre a formação de símbolos, refere que o indivíduo que está mais em contato com seu mundo interior tem mais facilidade de expressão simbólica de suas fantasias. A autora apresenta que

[...] A capacidade de comunicação consigo mesmo através do uso de símbolos é a base do pensamento verbal, ou seja, da capacidade de comunicar-se consigo mesmo por meio de palavras. Nem toda comunicação interna é pensamento verbal, mas todo pensamento verbal é uma comunicação interna por meio de símbolos-palavras (SEGAL, 1991, p.176).

É válido retificar que o símbolo como estamos aqui evidenciando trata-se de uma restauração ou re-criação, como propõe Segal (1991), de um objeto original no mundo interno da pessoa, são criações do ego. Entretanto, o símbolo "pode ser uma palavra, uma imagem, uma representação plástica, mas será requerida a introdução da linguagem para se conseguir uma expressão consciente" (MONTAGNA, s/d, p.60), uma das funções do encontro psicanalítico. Desse modo, uma criança muito pequena que brinca está sendo capaz de simbolizar e, portanto, significar uma experiência, ainda que esta experiência possa não ser nomeada por ela.

A possibilidade de brincar e, portanto, simbolizar é condição sine-qua-non para o desenvolvimento de uma criança saudável. O contrário também é válido, ou seja, a falta 
de acesso à simbolização pode prejudicar a capacidade da criança em usar o jogo como forma de exploração dos conteúdos de seu mundo mental, tornando a atividade do brincar inibida, estereotipada, repetitiva e, por vezes, ameaçadora, o que pode acarretar inibições maiores em seu desenvolvimento, e que pode ser exemplificado em Klein (1921-1945/1996), na análise de seu paciente Dick.

Tecendo considerações a esse respeito, Caper $(1996,2002)$ salienta o quanto a falta de capacidade para brincar é prejudicial para o indivíduo, isso porque brincar pressupõe contato com a realidade. Uma vez que o brincar é geralmente associado à fantasia, o autor sinaliza que, para que o jogo aconteça, as realidades externa e internas precisam estar separadas na mente. Dessa maneira, quando os mundos interno e externo podem ser independentes, símbolo e simbolizado podem permanecer como distintos, condição primordial para a possibilidade de simbolização. A confusão entre as realidades interna e externa, ou ainda, entre self e objeto leva o pensamento simbólico ao colapso.

No início da vida da criança, até por volta dos três, quatro anos, a separação das realidades interna e externa encontra-se prejudicada de maneira que a criança não separa o que pensa e sente daquilo que, de fato, acontece (MONTAGNA, s/d), o funcionamento mental opera em modos de "equivalência psíquica" (TARGET e FONAGY, 1996).

Target e Fonagy (1996) propõem que a realidade psíquica da criança pequena tem um modo dual de funcionamento, o que corresponderia tanto ao modo de 'equivalência psíquica', onde as idéias são tidas como réplicas da realidade, ou ao modo 'faz de conta', em que idéias são representações, mas não confrontadas com a realidade.

O modo 'faz-de-conta' garante, para a criança, a coerência psíquica. Permite à criança poder brincar sem sentir-se tão ameaçada por suas fantasias, uma vez que está muito mais à mercê delas do que os adultos. 
À medida que a criança cresce, essas duas maneiras de lidar com a realidade ficam cada vez mais integradas: gradualmente ela vai sendo capaz de separar as realidades interna e externa e estabelecer para si representações mentais mais acuradas. Target e Fonagy (1996) evidenciam o desenvolvimento de uma instância mentalizadora na criança que se faz na presença de um outro que, ao cuidar, possibilita, paulatinamente, a organização desses dois mundos, questão antes mencionada por Ferro (1995) e Winnicott (1971/1975). Assim,

[...] É a capacidade que a criança tem de figurar os estados mentais simbolicamente que permite que possa construir o mundo da subjetividade, no qual os sentimentos e os pensamentos podem ser reais e, ao mesmo tempo, não corresponder exatamente à realidade externa ou às versões que as outras pessoas têm dela. A qualidade do self nuclear determina o sucesso da integração dos dois modos [...] (TARGET e FONAGY, 1996, p.68).

A experiência clínica demonstra que o uso da brincadeira de 'faz-de-conta' na criança mais velha, que consegue fazer distinção entre a realidade e a fantasia, perdura ao longo do tempo. O 'faz-de-conta' pode funcionar como um trabalho de elaboração, na tentativa de simbolizar e, portanto, não somente representar seus conteúdos internos, suas fantasias, mas também transformá-los. A brincadeira de 'faz-de-conta' permanece na vida da criança possibilitando-a entrar em contato com questões de si própria que, de outra maneira, não poderiam ser expressas.

Cremos que a brincadeira sadia, qualquer que seja ela, na presença de "um outro", como anteriormente propomos, vai além de propiciar o contato com angústias inominadas e tentativas de elaboração de conflitos. A brincadeira, seja a criação de uma história, uma cena, um conto, é possibilitadora de transformações.

Algumas respostas para os questionamentos suscitados no início deste capítulo vão se delineando na medida que nos conduzem às questões do brincar como recurso 
simbólico, especialmente dentro do enfoque das intervenções psicanalíticas em um contexto de processos psicoterápicos.

Com isso, partimos da premissa que, por meio do brincar, em especial no caso de crianças que viveram situações traumáticas, o psiquismo tenderia ao movimento, ao invés de paralisia, como anteriormente mencionado. Isso também significa um psiquismo operando com vias de representação e, portanto, de símbolos.

Foi por intermédio do trabalho com crianças que sofriam de patologias cardíacas que a possibilidade de ajudar pequenos pacientes nessas condições tornou-se possível por meio das intervenções psicanalíticas. Movidos pelos questionamentos e pela inquietação, a possibilidade de atender essas crianças, ainda que por um breve período de tempo, pareceu-nos uma possibilidade alentadora de promover algo mais em seu desenvolvimento, frente à impossibilidade de muitos não poderem buscar o auxílio de uma análise prolongada. Ajudá-los, por meio da técnica do brincar, seria uma tentativa de oferecer um movimento entre a dialética na qual se instaura o traumático: construção e destruição (NOSEK, 2005) e, com o movimento, ajudar a fertilizar o terreno, a edificar o campo... 


\section{2 - A PESQUISA}

\subsection{OBJETIVOS}

Investigar a dinâmica psíquica de crianças vítimas de uma enfermidade grave.

Possibilitar a mobilidade da dinâmica psíquica de crianças vítimas de uma enfermidade grave, a partir da técnica lúdica e do trabalho de busca de representabilidade dos elementos traumáticos.

\subsection{CONSIDERAÇÕES SOBRE O MÉTODO}

\subsubsection{O Método em Psicanálise}

Desde que a psicanálise foi desvelada pelo seu fundador, é possível alimentar discussões a respeito de sua cientificidade e de seu alcance como modalidade de pesquisa; dois textos clássicos de Freud, "Introdução ao narcisismo" (FREUD, 191415/1996k) e "Os instintos e suas vicissitudes" (FREUD, 1914-15/1996b) já apontavam para essas questões. Sendo assim, uma vez que os preceitos psicanalíticos foram escolhidos para balizar este estudo, julgamos como necessário e essencial percorrermos esse método de investigação antes de explicitarmos os procedimentos 
que nortearão esta tese. Não procuraremos exaustivamente discutir os pormenores entre pesquisa e psicanálise e, sim, tecer um pano de fundo que possa abrigar nossa investigação.

Diversos trabalhos (BIRMAN, 1994; MEZAN, 1993, 1994; MEYER, 1994; SILVA, 1993; SAFRA, 1993, 1994; FONSECA, 1997; VIÑAR, 1997; FONSECA e BUSSAB, 2001; MIGLIAVACCA, 2001, LOWENKRON, 2004, 2005; HERRMANN, 2004; TANIS, 2004; NOSEK, 2008; KERNBERG, 2008; PERRON, 2008) procuram elucidar a investigação em psicanálise como meio de estimular as pesquisas, produções e contribuições para o saber psicanalítico, todavia, frequentemente, encontra-se em pauta um ponto: qual tipo de pesquisa é a psicanalítica?

É sabido que Freud concebera a psicanálise dentro de três âmbitos: um método de investigação, uma forma de tratamento e o conhecimento que o método produz, ou seja, a teoria. No sentido do método investigativo, sua pesquisa pautou, desde sempre, em sua esfera de trabalho e, em um esforço para que a psicanálise fosse reconhecida como ciência, apoiou-se veementemente em um modelo positivista. Tal modelo perdeu força ao longo de suas investigações e entrou em declínio quando Freud aventurou-se a conjecturar sobre a pulsão de morte (BIRMAN, 1994). No artigo de 1920, "Além do Princípio do Prazer", Freud menciona que o que se segue é da ordem da especulação e supõe a existência de uma pulsão sem representação, ou seja, sem possibilidade de ser concretamente verificada. Todo seu esforço para sustentar o discurso positivista é, então, minado, sem, contudo, deixar esmaecer suas investigações clínicas. Em contrapartida, um novo método surgiu e foi por ele inaugurado: o método psicanalítico.

Freud pautou suas investigações, a partir de outro referencial epistemológico (VIÑAR, 1997) com um ideal de ciência que difere da proposta atual, com a base científica tendendo para o positivismo e empirismo. Nesse sentido, pesquisar em psicanálise, seguindo seu legado, teria como premissa máxima a exploração do pensamento e a busca incessante de colocar em palavras o que anteriormente não poderia ser dito e pensado. 
Nessa perspectiva, o conceito de ciência, tradicional, positivista, ou seja, um conhecimento objetivo, generalizável e verificável, não se aplica. Isso porque o ser de expressão, falante, que é parte do nosso objeto de pesquisa, não é preciso e também não é dotado de lógica ou não-contradição, pelo contrário, não coincide consigo mesmo, é inesgotável quanto aos sentidos e às significações (VIÑAR, 1997).

Por outro lado, no que tange ao investigador, passamos a considerar que este, como sujeito que observa, está, inevitavelmente, à mercê de seu aparelho mental, sujeito às próprias percepções que este lhe confere.

Tem-se que a psicanálise imprime ao saber científico a noção de que a observação altera o observado rompendo o paradigma da neutralidade do observador. Ao levar-se em conta a subjetividade do sujeito que observa, a noção de verdade absoluta se esvai. Cada vez mais, tem-se presente que o conhecimento pode ser relativizado. Somando-se a isto, para além da verdade absoluta, conferimos ao saber científico a noção de construções e hipóteses que podem ser aprimoradas, atualizadas ou, até mesmo, reformuladas.

É incontestável que há, então, uma mudança no âmbito da pesquisa uma vez que se inclui a indeterminação e o aleatório (VIÑAR, 1997). O objeto da pesquisa que se refere a psicanálise é uma outra mente, um outro sujeito, passível de interação e inesgotáveis expressões. A investigação permeia esta experiência da relação que passa a ser singular com cada sujeito e que não pretende dar conta de tudo. Sobre este ponto, encontramos em Freud (1914-16/1996b) que nem as pesquisas das ciências mais exatas têm a presunção de trabalhar algum material sem isolar algumas variáveis, o que dirá a dimensão humana. Birman (1994) também insere essa discussão ao mencionar sobre o impossível de ser dito e sobre a inviabilidade de se saber tudo. Sobre essa questão, é válido lembrar que a psicanálise tem-se deparado diante de questões que fogem às capacidades de representação, ou seja, algo se apresenta, mas que não é dado saber. Ademais, essa é a trama do inconsciente: o desconhecido que se desvela. 
Diante desse panorama, esse modo peculiar de investigação psicanalítica dos fenômenos humanos é acurado, pautado na participação e construção de duas mentes e, portanto, dotado de duplo vértice: de um lado, a associação livre, baseada na oferta de material livre pelo sujeito, ausente de críticas (pensamentos, fantasias, sentimentos, sonhos, o que lhe vier à mente) e, de outro lado, a atenção flutuante do analistapesquisador que procura captar esse material sem crítica e expectativas préconcebidas. Somado a esses recursos, a experiência da transferência, como via de comunicação, configura-se como condição ímpar de auxílio à investigação psicanalítica, é por meio dela, da repetição de protótipos infantis reatualizada na relação do par, que é possível captar os elementos da psique humana.

Tendo como premissa os meios para atingir a citada investigação, consideram-se ainda como instrumentos valiosos da investigação psicanalítica, a contratransferência (simplificadamente, reação à transferência do outro) e a interpretação.

Cabe-nos ainda acrescentar a especificidade da pesquisa quando realizada com crianças, em destaque: o jogo, ou seja, o brincar como equivalente à associação livre, via de acesso ao inconsciente e ao desenho. O jogo como método de investigação, nesse caso, participa do contexto tal qual em uma sessão de análise. Através dele, a criança dramatiza, representa e comunica seu mundo infantil. Já o desenho pode ser um instrumento valioso que também funciona como uma forma de comunicação e auxilia na representação do mundo emocional da criança. Outros aspectos essenciais para conduzir a pesquisa de crianças permanecem semelhantes aos que já foram mencionados como necessários para o trabalho com os adultos, tais como entrevistas clínicas, escuta livremente flutuante, contratransferência, interpretação.

Estendendo um pouco mais rumo à investigação psicanalítica, em termos gerais (tanto de adultos quanto de crianças), há que se mencionar o tripé que sustenta o trabalho e, porque não, a pesquisa: a teoria, que nas palavras de Mezan (1993), vincula a singularidade do experimentado à universalidade dos conceitos servindo de ferramenta para "correlacionar dados, inferir hipóteses e sugerir derivações" (p. 59), a supervisão, que propõe auxílio ao pesquisador-psicanalista tanto nas discriminações 
das reações contratransferenciais, na tentativa de controlar os efeitos da subjetividade do pesquisador, quanto no recorte da pesquisa (SAFRA, 1993) e da auto-análise, uma vez que o pesquisador está implicado no fenômeno que observa e que, segundo Safra (1993), é o que permitirá "maior possibilidade de aproximação ao seu objeto de estudo: o psiquismo humano" (p.131).

Acreditamos que o método, quando bem estruturado e acatado com rigor, dirige os parâmetros da investigação e permite que a ela possa ser delineada em quaisquer que sejam os contextos, inclusive para fins de pesquisa. Os diferentes espaços clínicos são os lugares da pesquisa psicanalítica (BIRMAN, 1994). Silva (1994) sugere pensarmos que

Há pesquisa psicanalítica sempre que há interpretação das forças subjacentes a uma experiência humana ou seu produto, quer esta se apresente como uma relação entre pessoas ou como uma reação individual a qualquer coisa produzida pela mente humana. O importante é que se trate dessa busca da determinação desconhecida, e não da representação convencional e lógica, passível de mensuração e demonstração (SILVA, 1994, p. 48).

Acrescentamos a essa busca da determinação desconhecida o que fora mencionado anteriormente: uma pesquisa é dita psicanalítica quando ancorada firmemente no seu método, o psicanalítico.

Entendemos que a busca do saber e do conhecimento mediante a pesquisa em psicanálise é possível. Partindo de experiências pequenas e singulares, temos a chance de compor novos modelos e confrontá-los com outros outrora adquiridos, abrangendo as descobertas a fim de ampliar as construções.

É com base nesses pressupostos que se delineia este estudo. Todavia, com intuito de ajustar as condições desta pesquisa a todo aparato que compõe o saber 
psicanalítico, não poderíamos deixar de examinar as questões relativas ao enquadre. $O$ enquadre pode ser considerado parte integrante do método, passível de pouca flexibilidade, especialmente quando nos remontamos à psicanálise, chamada ortodoxa e a seus inúmeros seguidores. No que concerne a um reexame dessa questão, como fazer uma pesquisa dita psicanalítica com atendimentos restritos em um breve espaço de tempo, expandir as fronteiras do enquadre clássico e, mesmo assim, manter-se fiel ao método?

\subsubsection{O Setting}

Diversos trabalhos procuram elucidar a possibilidade das intervenções psicanalíticas em contextos diferenciados, como os de Mélega (1997), Barone (1997), Millan (1997), França M. T. B. (1997), para citar alguns. Parece fundamental considerar que o apelo a um contexto diferenciado ou a uma mudança do setting, deve-se, com muita frequência, à necessidade de um trabalho que seja significativo e eficaz, ainda que realizado em um determinado espaço de tempo, que tenha como balizador os conhecimentos psicanalíticos e que possa ser desenvolvido em outros contextos que diferem do enquadre clássico. A procura por esse tipo de intervenção se deve também a outros fatores, como a alta demanda de pacientes e as condições econômicas.

Diante dessas novas possibilidades, como ficaria o trabalho da psicanálise fora do consultório, sem o uso do divã, com moldes diferentes do enquadre clássico? O que dizer sobre o respeito ao setting (enquadre)?

Green (2008), psicanalista francês, propõe que o enquadre seja dividido em duas partes, o que facilita a compreensão do que muda e do que permanece o mesmo em um encontro em que os fins não são os de um tratamento psicanalítico, mas sim os de ajudar o paciente para que possa ser favorecido. Ele sugere que as partes do enquadre sejam pensadas tal como uma matriz ativa e um estojo. A matriz ativa seria composta 
pela associação livre do paciente e a atitude de receptividade e compreensão do analista marcada pela atenção e escuta flutuantes, par indispensável para a realização de qualquer intervenção; o estojo seria constituído pela periodicidade dos encontros, número e duração das sessões, modalidade de pagamento. Intervenções com enquadres diferentes do tratamento clássico partilham de diversos conteúdos de uma mesma matriz ativa, entretanto, diferem no seu estojo. $O$ autor ainda adiciona que, na falta de um enquadre análogo ao da psicanálise clássica, o analista possa fazer uso de um referencial interno, o qual foi internalizado na própria análise. Esse referencial interno de enquadre permite que $o$ analista salvaguarde as condições necessárias para a busca de mudanças, não deixando de estar regido por um limite de variações possíveis.

Dentro desse contexto, entendemos que o setting, ou o enquadre, contempla não apenas o conjunto de arranjos práticos para a realização do trabalho, mas também a internalização de uma postura dada pela função analítica (MIGLIAVACCA, 2008).

Acreditamos ser possível pensar em manter essa função analítica como parte do setting, ainda que seus arranjos práticos sejam modificados, com o avanço da teoria e da técnica psicanalíticas. A psicanálise antes estritamente pautada na descoberta do inconsciente e intimamente relacionada com a teoria da sexualidade avançou para as relações de objeto com Melaine Klein, para a teoria das transformações com Bion e deu ainda outro salto com Ferro e Ogden que valorizaram a contribuição real do analista na dupla (FRANÇA J. B. N. F., 1997). Com o foco na dupla, nos movimentos emocionais do par analista-paciente, algumas mudanças no modo de pensar a psicanálise se produziram como a necessidade premente da neutralidade do analista, o foco na teoria das pulsões e na sexualidade e possibilitaram uma intervenção psicanalítica sem o uso do divã.

De outro modo, mas caminhando também para uma modificação na teoria e na técnica, Alvarez (1997), em entrevista com membros da Sociedade de Psicanálise de São Paulo, elucida seu modelo de intervenção quando a necessidade é de uma mudança do setting clássico. A autora relata que há vários níveis de trabalho 
interpretativo: no primeiro deles, com base na teoria freudiana, as interpretações são explanatórias, do tipo causal, o paciente sente isso porque sentiu aquilo. No segundo nível, que teria como base a teoria kleiniana, as interpretações são de localização, o paciente sente isso e quer que o analista sinta também. No terceiro nível de trabalho, as interpretações têm a ver com a teoria bioniana, diferem das explicativas e de localização e prima por interpretações descritivas ou de continência. Alvarez acrescenta, ainda, um quarto nível em que as interpretações são impessoais, como: "é muito chato quando o trem não está no horário", e que a nosso ver se aproxima com alguns pressupostos da teoria de Ferro (1995), em que a fala do analista fica nos personagens da sessão. Nesse sentido, a autora menciona que com um paciente em que é necessária uma mudança no setting clássico, o trabalho de interpretação perpassa os níveis três e quatro.

A partir desse raciocínio, acreditamos que um setting que contemple um enquadre diferente do clássico é possível desde que se mantenha fiel à função analítica. Um exemplo de trabalho pautado numa modificação do setting pode ser encontrado nas descrições de Winnicott (1896-1971/1990).

Winnicott (1896-1971/1990) inaugura um novo campo de atuação ao mencionar duas opções cabíveis para uma situação-problema, fazer psicanálise ou ser um psicanalista que faz outra coisa. Assim como Alvarez (1997), Winnicott (18961971/1990) enfatizava que esta outra coisa, apropriada para uma situação onde a análise não era possível, não era psicanálise, mas que cabia à escuta dos psicanalistas. Em uma descrição feita por ele, após alguns relatos de consultas, menciona

Pode ser que algo desse material, não psicanalítico, tenha sido de interesse para analistas. Minha opinião pessoal é de que material não analítico interessa justamente aos analistas. Por exemplo, quando uma mãe consegue aos poucos juntar os pedaços da história do desenvolvimento emocional de seu filho, quem senão um analista poderia 
dar-Ihe o que ela precisa, ou seja, o reconhecimento de que todas as peças realmente encaixam-se umas nas outras e formam um todo? (WINNICOTT, 1958/2000, p.145).

A opinião por ele sustentada e que norteia a prática de muitos trabalhos realizados, especialmente em instituições, é a de fazer o máximo possível dentro do mínimo de tempo disponível. É possível que o paciente possa receber uma ajuda se o tempo que ele tem for bem aproveitado, o que depende de uma escuta psicanalítica desenvolvida. É de opinião de Winnicott, e também da nossa, que é através da psicanálise clássica que o indivíduo tem grandes possibilidades de transformação. Entretanto, esta só se constitui na melhor alternativa quando ela é possível. Como ajudar aqueles que não têm disponibilidade econômica-financeira, espacial, ou mesmo, temporal de se engajar em uma análise?

Era mediante o trabalho de consultas em departamento infantil que Winnicott aplicava os princípios de explorar integralmente as primeiras entrevistas (consultas terapêuticas) em sua clínica, com objetivo não de fazer um tratamento psicanalítico, muito embora usasse seus princípios, mas com intuito de poder fazer uso dos seus pressupostos de uma maneira breve a fim de promover um encontro significativo entre terapeuta e paciente com possibilidades de amadurecimento.

As consultas terapêuticas ganharam notoriedade por seu caráter flexível, uma vez que o setting, como conjunto de regras formais, não era específico, embora tais consultas fossem respaldadas em um rigor técnico; parte dessa técnica privilegiava o holding (o estar junto) à interpretação. Essa modalidade de intervenção serviu (e ainda serve) como modelo para inúmeros trabalhos posteriores de investigadores clínicos que acreditavam que a psicanálise poderia atravessar as fronteiras de seu contexto clássico.

Concordamos com a premissa de que o analista é quem melhor pode entender os fenômenos humanos e pode, portanto, oferecer benefícios para o paciente em 
diferentes contextos de atuação, não necessariamente fazendo psicanálise, mas fazendo bom uso de sua função analítica.

Considerando que o método atende às exigências necessárias para a pesquisa dita psicanalítica apresentaremos, a seguir, os esclarecimentos referentes ao estudo.

\subsubsection{Esclarecimentos sobre a Pesquisa}

O presente trabalho consistiu na investigação e intervenção com crianças que foram expostas a um evento potencialmente grave, como uma enfermidade grave seguida de hospitalização e cirurgia. $O$ trabalho foi realizado assim que a criança teve condições de ser submetida a uma intervenção psicanalítica.

Participaram das reflexões deste trabalho duas crianças vítimas de uma enfermidade grave: a cardiopatia congênita e que foram submetidas à cirurgia para correção anatômica. As crianças tinham entre cinco e seis anos de idade, de ambos os sexos, sem distinção de raça ou cor. Elas foram escolhidas aleatoriamente quanto ao tipo de cardiopatia, mas desde que tivessem sido submetidas à operação no máximo dois meses, que tivessem experimentado as limitações agudas e crônicas da condição médica grave e que não houvesse comorbidade com outras patologias. A escolha, por meio do Serviço de Cirurgia Cardíaca Pediátrica do Hospital de Base de São José do Rio Preto-SP, também priorizou as crianças residentes na cidade aonde foram operadas, com intuito de facilitar o acesso às intervenções, o que dificultou a seleção, uma vez que o citado Serviço atende crianças de todas as regiões do país.

O estudo consistiu de quinze intervenções psicanalíticas: três com os pais e doze com as crianças. O contato com os pais foi realizado no início do processo, no meio e no final. A entrevista inicial com os pais foi semi-dirigida focalizando aspectos da história de vida da criança e dinâmica familiar; entendemos que, ao coletar esses dados, mesmo sob a ótica de seus pais, auxilia-nos na compreensão da vida emocional 
desse pequeno paciente. Uma intervenção com os pais no meio do processo foi feita com o objetivo de esclarecimento quanto à dinâmica emocional do seu filho e orientação, uma vez que os pais participam ativamente e são responsáveis pelo bom desenvolvimento físico e psicossocial de suas crianças. No final, a sessão com os pais foi de fechamento do processo, com intuito de avaliar a experiência das intervenções psicanalíticas para a criança e a necessidade de iniciar uma psicoterapia.

Com as crianças foram realizadas doze sessões, dez sessões foram lúdicas e livres, ou seja, foram respeitados os princípios metodológicos utilizados no atendimento infantil: o jogo, como forma de expressão e comunicação do mundo interno da criança e como correspondente da associação livre, o desenho como veículo de investigação e comunicação, a atenção livremente flutuante, atenção à díade transferênciacontratransferência, todos com intuito de formular a dinâmica psíquica da criança e intervir sempre que necessário. As sessões tiveram duração de quarenta e cinco minutos cada uma. Duas sessões, uma no início e outra no final do processo, foram reservadas para aplicação do Procedimento de Desenhos-Estórias (TRINCA, 1997). As sessões com a criança foram registradas e, para fins de aprimorar a análise das entrevistas, os casos foram discutidos em supervisão com um psicanalista.

O referencial teórico adotado, durante todo o processo, foi o psicanalítico. A proposta foi de observação, inferência e intervenção e, nessa perspectiva, auxílio ao sofrimento da criança que passou por situações demasiadamente ameaçadoras ao seu desenvolvimento psíquico, com a proposta de acompanhá-la no confronto com questões que fogem da esfera de representações, favorecendo a não paralisação e o não congelamento de sua rede simbólica e de significados.

Com efeito, essa investigação se fundamentou sobre a perspectiva de que o trauma, por definição, é irrepresentável e que o traço perceptivo já é uma primeira forma de representação.

No início e final do processo com cada criança, foi realizada uma entrevista de aplicação do Procedimento de Desenho-Estórias, instrumento que reúne técnicas gráficas e temáticas de modo a se constituir em uma abordagem da vida psíquica. $O$ 
desenho-estória consta em até cinco unidades de produção realizadas pela criança, sendo cada qual composta por um desenho-livre, seguido da solicitação de uma estória com um título, a este conjunto se denomina unidade de produção. O Procedimento de Desenhos-Estórias foi utilizado, uma vez que é um recurso que tende a facilitar a expressão de aspectos inconscientes relacionados a pontos focais de angústias presentes em determinado momento ou em determinada situação de vida da pessoa. Como opção, utilizamos o Procedimento de Desenhos-Estórias com o tema, com intuito de focalizar o interesse da investigação: a doença e seus efeitos. A análise desse material coletado foi feita por meio da impressão geral dos desenhos e da análise das estórias. Este material serviu de apoio para a intervenção e avaliação do processo ao final.

Descreveremos, a seguir, mais minuciosamente um primeiro caso e utilizaremos fragmentos do segundo caso para complementar a discussão, correlacionando-os e refletindo sobre os pormenores de cada história e os efeitos das intervenções sobre cada uma delas. Esperamos, com essas reflexões, observar as movimentações e modificações na linha da representação de conflitos e possíveis mudanças na forma de as crianças brincarem e se expressarem graficamente. 


\section{3 - EXPERIÊNCIA CLÍNICA}

O primeiro paciente atendido foi $\operatorname{lgor}^{7}$. O contato inicial que tive com a mãe de Igor foi na Unidade de Terapia Intensiva, um dia após sua operação, que se realizou em 6 de janeiro. Estava aflita, esperando para ver o filho, além disso, estava aborrecida com o cirurgião que, segundo ela, havia dito que a culpa do filho ter nascido com cardiopatia era dela, por ter sido mãe com um pouco mais de idade. Não falei com Igor neste dia, apenas o vi de longe e o ouvi, aos berros, enquanto estava tomando um "banho" no leito da UTI. Minha intenção era apenas fazer o contato com a mãe para os fins da pesquisa e vê-lo, então, após a alta. Vim saber que, até aquele momento, a família não havia sido vista pela psicóloga e, tampouco, orientada; situação esta que, eventualmente, ocorre.

Encontro com a mãe, aproximadamente, uma semana após a alta de Igor, no dia 14 de janeiro, para a entrevista. Acha que serão proveitosas as sessões de intervenção psicológica e diz que tudo o que for para ajudar é muito bem vindo. A mãe vem sozinha, sem o pai, apresenta uma fala corrida, consigo fazer alguns direcionamentos da entrevista sempre a interrompendo, uma vez que fala sem cessar.

Igor vem de família de poucos recursos financeiros, a mãe trabalha como doméstica, mas deixou o serviço em função dos cuidados do filho e o pai é enfermeiro e trabalha com idosos em um hospital pequeno na cidade. A mãe tem cinquenta anos e o pai trinta anos e, além de lgor, o casal tem uma filha de dezesseis anos, fruto de um casamento anterior da mãe. Foi um filho planejado, mas que, de acordo com o relato da mãe, atrasado em todos os sentidos. Antes da descoberta da cardiopatia, teve algumas complicações importantes. Ao nascer, Igor sofreu uma queda, após uma manobra brusca da ambulância, onde nasceu sem tempo de chegar ao hospital. Na volta para casa, após uma bateria de exames neurológicos atestando sua saúde, nada continha seu choro. A mãe relata quarenta e cinco dias insaciáveis de choro e alimento, dizia

\footnotetext{
${ }^{7}$ Os nomes utilizados ao longo desse texto são fictícios
} 
que o peito (apesar de muito leite e de o bebê pegar bem) não era suficiente, que o filho só parou de chorar após o incremento da mamadeira e, nessa ocasião, "largou o peito sem problemas".

Igor, desde pequeno, não tinha peso e nem altura para a idade. Por ocasião de uma consulta médica de rotina, fora-lhe dito que ele tinha Mal de Simioto, nome popular, em algumas regiões do Brasil, da desnutrição causada por fatores sociais (como ausência ou substituição do aleitamento por leite comum), psiquiátricos (como anorexia), ou patológicos (como a incapacidade do organismo digerir as enzimas do leite). A mãe não soube dizer o que significava exatamente a doença. Nessa época, por volta dos três meses, o filho era ainda "pele e osso", deixou-o em uma creche para voltar a trabalhar e, devido ao baixo peso, todos tinham medo de pegá-lo.

Aos oito meses, Igor ainda não sentava, não engatinhava, não demonstrava sinais de desenvolvimento. Voltou a fazer exames, ficou cinco dias internado em um hospital e constataram que o que ele tinha era hereditário e que a história do pai era semelhante. Por volta de um ano e oito meses, Igor foi estimulado a andar com várias sessões de fisioterapia. Sua dentição apareceu depois do segundo ano e começou a falar por volta do quarto ano de vida, com sessões de fonoaudiologia.

A mãe relata que, aos cinco anos, o filho teve uma boa melhora, mas que a sua idade parecia ser de uma criança de três anos. Começou a acompanhar com o cardiologista, que diagnosticou o caso de Igor como cirúrgico, mas que não tinha como operá-lo, porque a criança não tinha peso nem altura para aguentar a operação. 0 pediatra tentou interná-lo para operar três vezes, sem sucesso. Ela cansou e deixou de lado o tratamento.

Em um episódio com a avó, o menino ficou "preto", cansava demais tentando brincar, a boca roxeou e a mãe, assustada, voltou a levá-lo ao cardiologista.

Foi internado às pressas por ter vaga para a cirurgia e operou sem maiores esclarecimentos da equipe. Na UTI, a criança chorava muito, na volta para a enfermaria 
ficou depressivo, não falava com ninguém, conversava por sinais e não comia. Melhorou quando foram tiradas as fraldas dele que usava na UTI.

Igor é descrito pela mãe como uma criança retraída que demora "três meses para fazer contato". Com toda expectativa do que poderia vir a ser o contato com uma criança com histórico tão difícil, recebi Igor para a primeira consulta.

\section{Entrevista Clínica 1}

A sala que me foi cedida para os atendimentos da tese é rotineiramente utilizada pelos clínicos da cardiologia pediátrica; possui uma mesa com cadeiras, um divã-maca, um armário, uma pia e um espaço razoável para que pudéssemos brincar. A monotonia da parede branco-hospitalar é quebrada por diversos corações com pernas e braços em diferentes movimentos e expressões, operados e sorridentes, adoentados e tristes, de óculos escuros e boné divertindo-se, dançando feliz, dois deles jogando bola alegres. A sala também possui duas janelas no alto, na posição horizontal, relativamente estreitas e que permanecem frequentemente fechadas. Penso que Igor estivera, algumas vezes, naquela sala, anteriormente. No dia da nossa primeira sessão, ele entra de cabeça semi-baixa, disposto, sorrindo discretamente ao me olhar e prontamente senta-se à mesa. Apresento-me, digo que nos veremos algumas vezes nos próximos meses e que ficaremos juntos para conversar um pouco e brincar, mas que antes, gostaria que ele pudesse me fazer alguns desenhos. Digo a ele que será uma sequência de desenhos e estórias que ele poderá me contar. No final, dou-me conta de que não solicito a Igor o tema sugerido: a sua doença, talvez porque a sala tivesse estímulos suficientes para mobilizá-lo, contratransferencialmente temerosa de sobrecarregá-lo.

Igor faz rapidamente os desenhos, tenta contar as estórias a seu modo. No final, guardamos os papeis e digo a ele que podemos fazer o que ele sugerir, uma vez que ainda tínhamos um tempo para o final da sessão, ele escolhe as massinhas. Sua brincadeira era jogar para mim e esperar que eu jogasse de volta as duas massinhas, 
vermelha e azul, na forma de bolas. Depois, jogava para o alto e ficava feliz quando conseguia acertar a pia. Enquanto fazia o movimento de lançar as massinhas, respirava fundo, não de um jeito habitual, o movimento com a boca aproximava-se a um sopro que ao invés de ser para fora, era para dentro. Mais uma vez pensei na sua doença, antes diagnosticada como sopro. Seria um sopro aflitivo? Penso que Igor se esforçava para estar ali comigo e, de qualquer maneira, dessa vez, significava para mim um sopro em busca de vida. Encerramos a sessão.

\section{Comentários}

Igor não me parecia assemelhar-se muito à criança descrita pela mãe. Ávido por contato, encontramos-nos um ao outro, rapidamente e o que ela sugerira que poderia durar meses para uma aproximação, fez-se em poucos minutos.

Seus quatro primeiros desenhos foram desorganizados e emaranhados (anexo 1), embora ele parecesse ter outros recursos para outro tipo de produção. Na última produção, emerge um novo "desenho": Igor tenta escrever seu nome. De quem é aquela história? (e não mais estória). O nome aparece confuso e também desorganizado. De quem provém a narrativa repetida do caminhão, do trem, do carro que se batem, trombam, explodem? Aparecem, no meio da história, elementos concretos: a borracha e o apontador, e outros elementos desconexos: a janela, o doutor. As estórias de Igor foram repetidamente fragmentadas sem um elo que pudesse fazer uma ligação, eram estórias cheias de lacunas.

Ao final dessa entrevista, dúvidas relativas à história real de lgor me vieram à tona: será que Igor conhecia algo do início da sua vida? Será que the fora contado algo do seu nascimento trágico, de ansiedades abundantes (mais ainda do que um bebê com um parto regular)? E todas as angústias de seu desenvolvimento? Falar somente aos quatro anos seria quase dar-Ihe uma sentença de criança muda. Quantas ansiedades mais teriam sido reativadas no momento em que acorda em uma unidade 
de cuidados intensivos? No pós-operatório imediato, a mãe foi taxativa: Igor conversava por sinais, demorou para voltar a falar.

\section{Entrevista Clínica 2}

Caminho com Igor, sorridente ao me ver, pelo corredor. Ele entra às pressas na sala, fecho a porta e ele se senta na cadeira. Apresento-lhe a caixa de brinquedos e tímido não se arrisca a abri-la. Penso no medo do desconhecido, na criança que foi me apresentada como retraída. Digo que vou ajudá-lo. Abro a caixa, percebo novamente a tampa relativamente dura, ele olha espreitando um princípio de curiosidade. Em seguida, coloca a tampa de volta, parece não querer se ater aos brinquedos dentro dela e volta-se à sua pasta de material gráfico. Fico com a impressão de que está cedo ainda para os brinquedos e de que ele está cauteloso, atento-me ao fato de ele não se interessar nem por remexê-los, talvez por querer retomar o contato possível no outro encontro. Pega novamente as massinhas, abre a caixinha, retira as cores e escolhe novamente a azul e a vermelha, penso em duas cores emblemáticas relativas ao coração. Sentamos no chão. No momento em que me sento, percebo instantaneamente as minhas mãos inteiras com coloração azul (parecido com tinta de caneta quando se espalha borrando os dedos) percebo-me, em um primeiro momento, desconfortável, pois a minha primeira associação é com as crianças cardiopatas que têm algumas partes do corpo (mãos, pés e boca) com coloração levemente azulada e depois busco procurar mentalmente a possível causa do borrão (caneta, papel, massinha). Distanciome de lgor por rápidos instantes ou me sinto tão concentrada em sua causa que, naquele instante, minha mente é que sofre borrões.

No chão, ainda, ele joga massinhas para mim e as devolvo para ele. A brincadeira evolui com as massinhas sendo jogadas, por ele, para o alto e quando vêm para mim, devolvo-as a ele. Em outra sequência, Igor brinca de fazer gols (cestas) na pia e fica feliz quando consegue acertar, repete os movimentos de jogar a massinha para o alto de maneira que ficassem presas em cima do armário, sugerindo grande dificuldade da minha parte para pegá-las. Em um desses momentos, Igor joga, sem 
querer, a massinha e me acerta. Assusto e peço para que ele se limite a outros movimentos e não a mim. Por duas vezes, sinto parte de seu sadismo querendo me atacar ou machucar-me. Digo firmemente que aquela brincadeira não seria aceita e que deve ser estranho para ele estar comigo brincando sendo que está em um lugar em que foi tão machucado por outras pessoas. Depois disso, Igor não volta a fazer novas tentativas de ataque.

Joga a massinha para debaixo do armário custo em pegá-la, abaixando-me, de modo que ele sumisse da minha vista. Ele se esconde embaixo da maca. Procuro-o, chamo por seu nome e ele me assusta quando chego perto sem encontrá-lo. Igor repete essa brincadeira várias vezes jogando propositadamente a massinha embaixo do armário para que ele sumisse de minha vista. Em determinado momento, a brincadeira se inverte e eu passo a jogar a massinha para que ele tenha que pegá-la e, depois, me procurar. Em um momento em que não me encontra, desliga a luz, abre a porta e sai. Igor apenas finge que vai sair, mas, por alguns segundos, fico com receio de que ele de fato sairá, uma vez que fecha a porta para o lado de fora e depois a abre novamente voltando para a sala. Diz-me que tenho que esconder embaixo da maca e não embaixo da mesa. Concordo com ele. Vim perceber depois que, ao me esconder embaixo da mesa, perco-me, de fato, de sua vista. Inverte novamente o jogo, diz que eu é que tenho que procurá-lo, depois sair, apagar a luz (desistir dele) e voltar, assim o faço para depois ele novamente me assustar com a sua presença.

Igor volta a jogar a massinha para a parede tentar fazer gols. Diz que ele tem que acertar na parede (em um lugar determinado) para fazer gols e eu o mesmo. Fico para fazer gols nos desenhos de coração. Depois ele inverte os lugares e fará gols nos desenhos da parede. Pede água e interrompemos o jogo saindo da sala.

$\mathrm{Na}$ volta para sala, senta-se à mesa, abre a pasta e escolhe o que quer fazer. Pega tinta. Pegamos os papéis e o pincel e ele começa a desenhar, um mar... Vermelho. Depois me passa o pincel e pede para que eu desenhe... Um sol e depois uma casa. Ele pinta a casa de azul. E, em seguida, quer pintar as mãos. A sessão está bem no final, vamos até a pia, ele me pede para pintar suas mãos de azul e coloca 
sobre o papel. Encerramos a sessão em seguida. Ao sairmos da sala, ele pede mais água e comenta estar com muita sede.

PS: Lavo minhas mãos no meio da sessão e lgor também, o que sugere a possibilidade sim de ele ter visto minhas mãos azuis.

\section{Comentários}

Não parece ser, por acaso, que Igor interrompe a sessão para beber água e volta a querer bebê-la ao final da sessão, porque está com "muita sede" - ele se empenha arduamente, durante os quarenta e cinco minutos, em elaborar seus conflitos.

Igor joga a massinha para um lado e para o outro, sem saber aonde vai cair, ora esperando que algo a contenha, ora esperando que eu a segure. Uma massa jogada que tem gente que segura, tem gente que não, uma massa-vida. No jogo da massinha para lá e para cá, Igor tenta elaborar suas angústias: o jogo para debaixo do armário e o apagar das luzes lidam com a presença-ausência, com o aparecer-desaparecer, apagar e voltar tão marcante em sua operação, na anestesia geral, nos medos, no escuro, na ausência dos pais e de tudo o que ele reconhecia como identidade. Depois, ainda com a massinha, tenta fazer acertos no coração desenhado na parede, coração este que brinca e joga bola apesar de ferido.

Igor mostra, ao desenhar, que precisa de um sol, apesar de ter retomado a vida. A cirurgia traz a esperança de uma vida concreta, mas a vida emocional, como esse sol que brilha, ele parece que nesta sessão soube onde encontrá-lo.

\section{Entrevista Clínica 3}

Marcamos um novo encontro duas semanas após. Na semana anterior, o pai de Igor sofrera um acidente de moto, no dia anterior à sessão, e a mãe esqueceu-se de 
trazê-lo. No telefone com a mãe, a confusão foi tamanha que, em um primeiro momento, tive a sensação de que Igor é que tivesse sofrido um acidente, após meu susto e os esclarecimentos sobre o acidente, remarcamos. A semana que seguiu foi feriado e o ambulatório não funcionou normalmente, de modo que um intervalo grande acabou acontecendo entre uma sessão e outra e de maneira que eu nem pudesse ter a chance de conversar com Igor sobre esses imprevistos, o espaço entre as sessões foi de exatos dezoito dias. Antevendo os desdobramentos possíveis desse intervalo para o andamento do trabalho, antecipei, por angústia minha, a sessão.

Igor está à minha espera com os pais, a mãe em pé aguardando e o pai com um braço engessado sentado. A mãe me avisa, pela segunda vez, que Igor virá só com o pai para a próxima entrevista. Ele adentra o corredor apressado, passa por mim, sorri, entra na sala, fecha a porta e me deixa do lado de fora. Pressiono um pouco para entrar, ele não deixa e segura a porta com força. Penso "será essa a angústia da sessão?". Bato à porta, ele não abre, dou uns toques esperando resposta e ele se comunica. Mais uma vez, bato e ele bate de volta. Preocupo-me com ele lá dentro, com a porta fechada sem que eu possa vê-lo. Abro uma frestra que ele segura ainda com força para não ceder, digo a ele que é ruim ficar do lado de fora e peço para que ele me deixe entrar. Segurando a porta para não fechar ele cede, e eu é que a abro, entro falando sobre a experiência de ficar do lado de lá (de fora) e que isso me fazia pensar que não nos víamos já havia algum tempo.

Igor senta-se à mesa e debruça sobre a caixa para abri-la enquanto conversamos sobre o acidente do seu pai e sobre o feriado de carnaval. Conta-me que sua mãe não o deixou pular carnaval que teve perto de sua casa. Com muito esforço, tento entender o que Igor me diz, não só nesse momento, e em muitos outros durante esta sessão. $O$ dado real é que Igor tem uma fala muito precária, suprime muitas letras, especialmente o "s", o que dificulta muito a comunicação, mas outro fato, o que nos interessa, é que, todo o tempo, parecia que havia algo desconexo entre nós dois e elaborar a distância e essa desconexão foi o que Igor tentou durante toda a sessão. 
Abriu a caixa e pensou em voz alta: "o que vamos brincar hoje...?" Vasculha a caixa, encontra coisas que não havia visto e se surpreende. Pega duas mini bolas de futebol, coloca-as sobre a mesa, diz que acha legal, ameaça brincar com elas, mexe na caixa novamente e encontra mini carrinhos, pergunta-me qual eu quero, digo: "posso ficar com este" e aponto o de modelo mais antigo, ele pega o outro para si, em um primeiro momento, os carros colidem. Em seguida, os carros andam, sem colidir, passam próximos um do outro, raspando, mas não batem. Igor vai até a caixa e procura mais carros. Mostro a ele que só existe um carro de bombeiros, de tamanho mediano e um caminhão, de tamanho um pouco maior. Ele os tira da caixa, enfileira os carros na mesa, diz que a escada do bombeiro se parece com o trilho do trem e que pode ser um. $O$ jogo nesse momento era enfileirar os carros, passar um a um atravessando o trilho do trem. Esse movimento foi repetido muitas vezes por ele, cuidadosamente, ele segurando de um lado do trilho e eu do outro, enquanto ele checava se o carro passava. "Passa?" ele perguntava e constatávamos, "passa". Vez ou outra, quando eu é que tentava passar o carro ou fazia um movimento diferente, Igor ficava contrariado. Nesses momentos, ele dizia o que eu teria que fazer e quanto mais ele tentava dizer, algumas vezes ocorreu que eu menos o compreendia, o que contribuía para aumentar a minha impressão de que havia um choque entre nós, como a colisão dos carros.

Pois bem, Igor interrompe o jogo, pega na caixa o telefone. Dá-me a bolinha para que seja o meu telefone. Disca, faço o barulho do telefone tocando e eu atendo:

T - Alô?

$P$ - Alô, quem fala?

T - É a Flávia.

P - Oi, Flávia! Tem carro aí?

T - Tem. Vem brincar!

P - Então tá, tô indo. Beijo. 
T-Beijo.

Igor coloca o telefone no gancho e volta a brincar. Faz isso também outras vezes, interrompe o jogo, pega o telefone, liga-me e volta a brincar.

Pega a bolinha. Desta vez, jogamos bolinha ao invés de massinha. Ele insiste contrariado que eu tenho que de jogar as bolinhas juntas para ele, as duas. Ora o jogo das bolinhas flui, ora parece pouco entrosado. Uma bolinha vai para debaixo do armário, como na brincadeira das massinhas, quando abaixo para pegar, Igor desaparece. Procuro, procuro, não o encontro, de repente, um barulho. $O$ jogo das massinhas para a bolinha mudou. Desta vez, tem um suspense no ar. Paro, ouço o barulho com um fundo de silêncio. Espreito o barulho, ele se repete. Digo que parece sim ter alguém ali. Quando me abaixo sobre a mesa para encontrá-lo, Igor não se move, finge passar-se despercebido, continuo a procurar como se não houvesse o encontrado. De repente outro barulho, dou um toque na mesa, ouço uma resposta, de novo bato e de novo ele responde, até que bato e ele não me responde mais. Pergunto onde será que ele está...? Paro de falar subitamente, com som da cadeira se mexendo para dentro da mesa, como quem leva um susto, puxo-a arrastando de volta, ele puxa arrastando para dentro, nesse momento, termina o tempo da nossa sessão, puxo a cadeira, agacho até o chão onde ele está e digo que nossa sessão acabou. Ele se levanta sorrindo, lamentando com um "Ah...!!" batendo a mãozinha sobre a perna. Digo que nos reencontraremos em breve. Abro a porta e ele sai correndo pelo corredor.

\section{Comentários}

Penso em um Igor esperto, inteligente, de muitas vivências, que fala sim, embora com dificuldade. Estaria Igor me chamando o tempo todo para o jogo que eu resistia em compreender? Estaria eu, mais do que ele, impregnada pela falta e pela desconexão?

Logo no início, na entrada da sessão, deixando-me para fora da sala Igor comunica a falta. Falta que eu não soube conter, preocupando-me do lado de fora sem 
poder acolher o que ele me comunicava. Falta esta que senti com muita angústia e me esforcei para não ficar de fora da sala. Ele conversa, sobre o acidente do pai, sobre não poder brincar carnaval, sobre uma semana de angústias. Convida-me para a brincadeira como quem está disposto para uma conversa na sala de análise e que sinto que demoro a entrar, os carros que trombavam agora se aproximam com todo cuidado, aliás, os carros vão, um por um, cruzando o trilho-ponte, para ver se "passa", se chegam do outro lado, se chegam até mim.

Pega o telefone, brinca de ligações. E, assim, em uma ligação para mim, Igor pergunta se ali tem instrumentos para que se possa brincar, quando digo que sim, convido-o e podemos brincar realmente juntos, em sintonia. A brincadeira das bolinhas trata-se novamente de um jogo que parece ser central para lgor - o de sumir, desaparecer e depois reaparecer. Um jogo que parece conter situações novas e antigas. Nessa brincadeira em que fico no lugar da pessoa que se angustia com a ausência dele e permaneço angustiada sem encontrá-lo, finalmente posso sentir o que Igor me comunica e devolver para ele como algo suportável. Esse personagem que coube a mim o papel, não encontra, não acha, não vê, não sabe o que está acontecendo, sente-se perdido. Essa parece ser a história de Igor que permanece muda na fala, mas não na vivência a qual quer muito me contar lamentando-se quando a brincadeira acaba.

\section{Entrevista Clínica 4}

Encontro Igor no corredor da pediatria com o pai. Ele vem até mim, atravessa a meia-porta que dá acesso a um corredor com a cabeça baixa, ainda sob o olhar do pai e, depois, ao atravessarmos a outra porta que dá acesso às salas, olha para mim, sorri e corre até a sala, deixa a porta entreaberta e, assim que entro, ele se esconde embaixo da mesa. Pergunto: "Ué!!! Cadê o Igor?" e ele imediatamente aparece. Abre a caixa, remexe os brinquedos, pega as bolinhas e as coloca de lado. Tira os carros, e diz "vamos brincar disso?" Digo que sim. Pergunta sobre o trilho que, em seguida, juntos procuramos. Coloca tudo sobre a mesa, inclusive o telefone deixa de lado, a postos 
(quase como "caso eu precise"). Enfileira os carros e segura o trilho, enquanto seguro do outro lado para ele passar os veículos. "Passa?" ele pergunta. "Passa", ele mesmo responde e, em seguida, também respondo "passa". Nesse momento, Igor começa contar histórias sobre trens com um conteúdo semelhante, todas são trágicas. Entendo pouco o que Igor diz, uma vez que troca muitas letras e a fala é corrida parecendo aflitiva. O conteúdo das histórias é mesmo de aflição, a menina morre atropelada pelo trem, o trem atropela o carro que fica no meio do trilho. Entre uma história e outra, ele me diz "vc viu? No Gugu?" ou "passou no Gugu", o que entendo bem é que, em todas elas, o acidente, a tragédia catastrófica está presente. Enquanto ele me conta, no momento da sessão, penso em seu acidente mais recente, sua operação (embora Igor tenha outros) e vou acolhendo suas histórias angustiadas dizendo o quanto são tristes, difíceis e realmente trágicas e o quanto esse trilho de trem que ele me conta é um lugar muito perigoso e com muitos fatos e lembranças dolorosas. Em uma destas histórias, em especial, Igor insere um doutor. Digo que se parece com a sua história de ter sido operado. Ele diz que sim, menciona algo sobre o peito, pega a bolinha e se afastando da mesa me chama para jogar. Sinto que ele se afasta também da conversa que eu estava tentando inserir.

Jogamos um para o outro, brincamos de fazer gols, cestas, chutamos a bola. A cada abaixada minha para pegar a bola, ele se esconde, mas, em seguida, depois de eu perguntar "Mas cadê o Igor?", ele aparece descontraído, dando sequência ao que estávamos fazendo. Isso acontece todas as vezes que dou as costas a ele para pegar a bolinha que cai no chão, quando some da vista. Algumas vezes em que a bolinha caía e que o mantinha no meu campo de visão, Igor não se fazia desaparecer. Mas o aparecer e o desaparecer pareciam ser o cerne da brincadeira e ele opta pelo jogo. Primeiro ele esconde, procuro e não o encontro, até que ele sai debaixo da mesa, fazse visto e diz que é a minha vez de esconder. Eu escondo e dessa vez, angustio-me por ser a personagem que não é encontrada, que o outro (Igor) sai da sala, apaga as luzes e me deixa só, até que me encontra. Dessa vez, ele se esconde novamente, procuro-o, ele emite sons, dando-me pistas de encontrá-lo. Continuo perguntando por ele, digo o quanto é ruim ficar só. Mexe a cadeira para que faça ruídos, joga o cesto de lixo de debaixo da cadeira para longe, várias vezes, tentando surpreender-me, 
assustar-me. Depois de muitos sinais, vou até ele, que paralisado, finge não ser visto. Digo, novamente, que não o encontro e o continuo procurando, até que ele sai debaixo da mesa, faz um movimento de dar-me um susto, novamente, finalmente aparecendo.

Igor pede para brincar de tinta, como faltam três minutos para o término do encontro digo que não dá tempo, que temos pouco tempo, mas que podemos brincar no próximo encontro. Ele, então, sugere para brincarmos de massinha, digo que sim e jogamos um para o outro até o final da sessão.

\section{Comentários}

Um acidente, pela sua própria definição, está relacionado a qualquer acontecimento inesperado, infeliz e desastroso, capaz de ter uma consequência, causar um dano. Ao pensar nos acidentes de Igor, imagino o mais recente, talvez pela razão de ele estar ali comigo, mas teria um acidente mais marcante do que ocorreu no início de sua existência? Não podemos inferir exatamente qual destes acidentes prevalece, nesse momento, como causador de suas ansiedades, nem negligenciar nenhum desses acontecimentos como importantes fatores de surpresa e susto e, portanto, potenciais traumáticos, mas podemos supor que a operação tenha reativado suas angústias preexistentes. A final, Igor tenta, durante vários momentos da sessão, exporme à surpresa e ao susto.

Quando Igor menciona o doutor, naquele momento, ocorre-me que são fragmentos de sua cirurgia. Intriga também em suas histórias, além da catástrofe, a presença constante de uma menina.

Escrevendo a sessão, atenta aos movimentos repetidos de aparecimento e desaparecimento de Igor, lembro-me de que menciona "gugu" e me recordo de uma fala antiga da criança pequena que emite os primeiros sons "gugu-dada".

Imagino que o carro que "passa" pelo trilho do trem na brincadeira de Igor tem muitos sentidos que podem ser construídos de diversas maneiras: penso nos fatos ocorridos (queda, operação), será que passam? Será que atravessam uma ponte? Será 
que vão para o outro lado, de outro jeito? Deixarão de ser um passado sempre presentificado, para ser um presente que almeja a um outro lugar, um futuro? Ou, ainda, será que os carros passarão ou ficarão presos nos trilhos expostos a um novo acidente? Sua história afetiva é de angústia. Dentro da história da dupla, caberia um outro sentido: será que os carros passam para o outro lado, Igor terá acesso a mim? 0 telefone fica ao lado, caso ele precise me ligar, embora dessa vez não precise.

Parece-me que do que Igor mais necessita é o encontro - vem ávido por ele logo na primeira entrevista. No imaginário da mãe, Igor demora para se encontrar com o outro. Talvez esse seja seu acidente mais dramático, reativado em momentos de extrema angústia como a operação: o desencontro - a primeira experiência de Igor com o continente primário, falta de rêverie. Igor, uma criança que nos sugere ser dotada de alguns recursos, procura todo o tempo continente com rêverie, precisa do olhar, porque, na falta dele, o desencontro acontece e ele some; joga a massinha para ver se alguém segura ou não segura; precisa de um trilho-ponte que possibilite um encontro. Igor repete suas brincadeiras e, aos poucos, conta-me sua história - seu eu me esconder, vc me procura?!.

\section{Entrevista Clínica 5}

Ao lado do pai, Igor sorri para mim ao me ver no corredor. Chamo-o para entrar e ele, apressado, segue na minha frente, em direção à sala. Passa pela porta, deixa-a entreaberta e se esconde debaixo da mesa. Quando entro, pergunto: "Ué! Onde será que está o Igor?" Ele tira a cabeça para fora da mesa, com o corpinho ainda escondido e se mostra para mim, emitindo um som. Quando digo um "ah, vc está aí..." ele sai debaixo da mesa e vai até a caixa.

Na caixa, Igor mexe nos brinquedos já conhecidos, mas busca algo novo. Tira o dominó e ambos sentimo-nos entusiasmados com a nova brincadeira. Ele dispõe as peças de cabeça para baixo, pede que eu tire as minhas enquanto ele tira as dele. Pergunto se são sete e ele me responde que são oito. Começa a contar suas peças, 
esconde para que eu não as veja, coloca-as na caixinha e, em seguida, diz que não cabem as oito. Despeja novamente as peças sobre a mesa e reinicia a contagem. No início, tenho a impressão de que realmente vamos jogar, mas a contagem fica confusa e os números embaralhados. Igor desiste do jogo, diz-me que podemos guardar e escolhe outro brinquedo. Será que lgor me diz que o novo desperta, além de curiosidade, medo?

Devolve o dominó à caixa e procura o trilho do trem. Pergunta-me onde está e o ajudo procurar. Coloca sobre a mesa o trilho e pega o avião. Seguramos o trilho, tenta fazer com que o avião passe sobre o trilho sozinho (por fricção). Depois tira a cerca da caixa e a coloca fechando a passagem do trilho; tira os carros da caixa e os coloca sobre a mesa, enfileirados. A cerca sai da frente do trilho, o trem já não está mais passando, os carros e o avião podem atravessar: ora um por vez, ora em duplas. Igor e eu vamos, aos poucos, conversando sobre essa passagem e ele conta novamente de acidentes, mas, desta vez, não muitos. Em um momento, pede-me para brincarmos de outra coisa.

Pega as massinhas, joga para cima do armário, sinto que ele se decepciona. Pergunta-me o que faremos, arrasto, então, a maca e subo para pegar as massinhas. Pega as massinhas, devolve-as à caixa e diz que prefere as bolinhas. Tira as duas bolinhas da caixa, entrega-me uma delas e começamos a jogar, desta vez, para cima do armário. O propósito do jogo, já no início, é que a bolinha pare em cima do armário. Mas, na maior parte da brincadeira, ela bate em cima do armário, pinga várias vezes e volta a cair no chão. Ele vibra quando consigo que a minha bolinha fique e ele se empenha depois para que ele consiga também. Ambos sentimos muito pelas vezes que não dão certo, mas vibramos quando ele consegue, batemos com as mãos e continuamos o jogo. Chama-me atenção o fato de que, nessa brincadeira, Igor não se esconde a cada vez que pego a bolinha no chão, assim, não "desaparece" quando o nosso contato é desviado.

Do meio para o fim da sessão, após o jogo de bolinhas, Igor pede para que eu me deite na maca, sinto, novamente, a possibilidade de algo novo querendo surgir, 
limito-me apenas a movimentar-me em direção à maca e deito-me aguardando a aproximação de Igor do que sinto ser angústia. Ele fala algo que pouco compreendendo e que remete à operação e falo apenas sobre estranheza de estar deitada naquela maca. Ele, rapidamente pega o violão, corre para debaixo da maca e começa tocar. Eu me levanto da maca e digo "nossa, olha que som agradável... Parece ser de um violão... De onde vem...?!!" Ele sai debaixo da maca, coloca o violão em cima dela, ao

meu lado, automaticamente pego e começo a tocá-lo, achando interessante a possibilidade da música que surgiu na sessão. Ele se esconde novamente embaixo da maca, e acompanha o violão que toco com algumas batidas na maca. Em seguida, começo a procurá-lo, digo que a música estava tão interessante, mas que, naquele momento, já não sabia mais onde ele estava... Procuro-o, chamo pelo seu nome, vou até a maca, abaixo-me até ele, "não o encontro". Escuto um barulho, dessa vez, intenso, vindo debaixo da maca, assusto-me. O barulho fica forte e mais forte, assemelha-se a pancadas. Digo que muitos barulhos assustadores estão vindo dessa maca, barulhos fortes, perturbadores. Até que ele sai debaixo dela ao som de um "ah!".

\section{Comentários}

Nessa sessão, fico atenta como Igor é sensível aos movimentos da dupla. No início da sessão, sinto-o mais rápido para o encontro, aparecendo logo em seguida quando chamo seu nome. Na caixa, busca o novo e parece estar pronto, mas, ao menor sinal de desencontro, Igor sugere frustrar-se: "pergunto se são sete, ele me responde que são oito" e, em seguida, desiste do jogo. Será que o encontro tem que acontecer exatamente como Igor o idealiza? Será que se desorganiza à menor frustração?

Seguindo essa conjetura, o modelo da relação adesiva teria algum sentido nessa história. Igor cria o objeto e se aborrece quando a expectativa idealizada não acontece. Não podemos deixar de mencionar que Igor falta à sessão anterior, o pai desmarca alegando dificuldades com a escola do menino em liberá-lo. 
Todavia, com o trilho do trem a postos, ele tenta recuperar o encontro. Sem a cerca que impede a passagem dos carros pelo trilho do trem, o avião passa, os carros atravessam ora sozinhos, ora em duplas e novamente nos aproximamos um do outro.

A sessão sugere que, por meio desse encontro, Igor também tenta lidar com esses conflitos de aproximação e afastamento, com a fantasia de separar-se e ficar grudado, de ficar preso e depois sair, como na massinha que joga em cima do armário ou das bolinhas que espera que fiquem lá, mas que depois saiam. Lida com outras formas de vínculo sem precisar se desorganizar tanto.

Não há como deixar de associar todos esses conflitos, inerentes à historia pessoal de Igor, com sua operação. No final da sessão, a maca surge anunciando que, além de todas as situações potencialmente traumáticas sofridas, ela ainda produz muitos barulhos, barulhos fortes e ameaçadores que podem, quem sabe um dia, com experiências mais satisfatórias de vínculos e continentes com rêverie tornarem-se sons mais suaves ao coração, ou quem sabe, até música. A maca que, paradoxalmente, trouxe experiências aversivas e invasivas a lgor, pode agora também ser palco de experiências acolhedoras.

\section{Entrevista com os Pais}

Ambos, pai e mãe, vêm para a entrevista; o pai sorri discretamente, com os braços ainda engessados, sob tipóia, aparência mais nova do que a própria idade e franzino. A mãe, mulher de meia idade, por vezes, aparentando um pouco mais de idade do que tem, é firme, com timbre de voz forte, apóia a bolsa sobre o colo e se dispõe a falar quando pergunto sobre o filho. Os dois dizem que Igor está difícil e reclamam sobre questões referentes aos limites da criança.

Questiono quem é que coloca os limites e como isso é feito e a mãe diz que praticamente tem dois filhos em casa, porque o pai não é pai, parece irmão e lida com Igor como se fossem irmãos. Os dois são "iguais", como dizem tanto o pai quanto a 
mãe, fazem muitas coisas juntos quando podem, dormem juntos, brincam, conversam, saem, não desgrudam. Tudo o que acontece com Igor ele conta ao pai, com quem tem relação melhor, embora esse jeito mais comunicativo tenha se intensificado depois das intervenções psicanalíticas. O pai refere que antes Igor era meio ausente e que, certa vez, a psicopedagoga mencionou que a criança parecia não ter dimensão do que acontecia ao seu redor. O pai menciona que Igor sempre foi muito introspectivo como se não entendesse nada do que acontecia com ele. Digo aos pais que, provavelmente, Igor absorvia sim o mundo ao redor sem conseguir se comunicar.

A mãe diz que não é tão próxima da criança, acha que ela sim é que coloca limites e, como ela mesma menciona, prefere castigos (ao invés de bater). Sente que não é amorosa e acolhedora - diz que nunca fora assim. Fica evidente que a aproximação de Igor é com o pai, embora seja uma paternidade confusa. A função paterna parece estar ausente na relação, o próprio pai diz que não se sente pai e fica feliz quando dizem que ele e Igor parecem ser irmãos. Ele atribui o não se sentir pai ao fato de ser muito novo e de uma crença, baseada em uma fala médica, de que nunca poderia ter filhos. Nesse momento, começa a me contar a história do nascimento de Igor enquanto a mãe permanece calada.

A gravidez de Igor fora uma surpresa para o pai, pois ele não esperava ter filhos, uma vez que a mãe já era mais de idade e o pai, devido a um problema hereditário, não teria chances de poder fazer filhos. Entretanto, a gravidez foi aceita, em especial, para mãe que desejava ter um segundo filho (e que mencionou, na entrevista inicial, ter sido uma gravidez planejada).

As questões referentes ao nascimento traumático de lgor foram, aos poucos, ficando mais bem esclarecidas com o relato do pai, a mãe observa atenta ao relato, adicionando alguns pontos e dizendo o quanto, naquele momento, ela estava muito atordoada.

A ambulância foi chamada às pressas com a mãe já em trabalho de parto. Sem tempo de ir ao hospital, Igor nasceu na ambulância em frente à própria casa e o motorista da ambulância, na ocasião, foi quem fizera o parto juntamente com a 
enfermeira. Com o cordão umbilical, ainda ligado à mãe, Igor escorregou das mãos da enfermeira e caiu no assoalho da ambulância, o pai diz que gritou: "você deixou meu filho cair!!" . Segundo ele, a enfermeira desesperada pegou o bebê e, ao se levantar do chão, bateu a cabeça de Igor no braço da maca que estava abaixado na horizontal, o pai diz que Igor tem até hoje a cicatriz do machucado. A nosso ver, o pai parece estar bastante certo.

Nessa entrevista, o pai ainda menciona a anemia hereditária do filho, esclarece sobre um dos programas a que ele mais gosta de assistir há pelo menos oito meses: " $\mathrm{O}$ que aconteceu comigo", onde pessoas contam histórias sobre acidentes em um programa de tarde do Gugu Liberato.

Quando perguntado sobre o que Igor sabe sobre o que aconteceu com ele, os pais dizem que nunca the fora dito nada e que, na época, comentavam muito, mas que depois o assunto foi esquecido.

Quando questiono o que eles associam por volta dessa época (oito meses), o pai lembra-se de uma forte depressão que ele (pai) sofrera e que Igor tinha dificuldades para aceitar ficar em casa.

A entrevista chega ao fim, com o tempo acusando seu término, interrompendo a fala dos pais.

\section{Entrevista Clínica 6}

Vejo Igor sentado na sala de espera conversando e sorrindo baixinho com o pai. Ele me vê e vem até mim, digo para que ele espere um pouco que entraremos em seguida. Converso com a secretária sobre um computador alojado na sala de atendimento, tomando toda a mesa, vou novamente à sala, tento ajeitar o computador para tomar menos espaço e volto para chamar Igor. Ele vem, passa por mim e corre até a sala, sem que eu possa avisá-lo sobre o computador. Chego logo em seguida, vejo-o se espantar e correr para debaixo da mesa. Pergunto sobre ele, digo que tem algo 
diferente na sala hoje; ele logo sai de debaixo da mesa, vai em direção ao computador, olhando ressabiado com certa estranheza. Digo que ele deve realmente estar achando muito estranho, explico que o computador, provavelmente, ficará sobre a mesa nas próximas vezes que voltarmos à sala. Ele abre a caixa e tenta colocar seus carros sobre a mesa e diz que não dá. Percebendo seu desconforto e aborrecimento por querer ocupar a mesa sem espaço suficiente digo que sei que ele é muito sensível para essas mudanças e que, por hoje, poderemos tentar colocá-lo no chão. Disponho o computador no chão livrando a mesa e ele se tranquiliza.

Igor agora pode colocar o "trilho" e seus carros sobre a mesa, pergunta-me se vi no Gugu a história. Pergunto sobre qual história e ele diz: "do trem...". Peço para que ele me conte e ele relata um acidente do carro que bateu no trem. Quero estender a conversa e perguntar sobre esse acidente e ele levanta, pega o violão. Extasiada com a mudança de brincadeira ele me chama "Vem!".

Pega o violão e toca enquanto acompanho com batidas seu repertório, dessa vez, mais prolongado. Igor e eu tocamos e dançamos.

Volta o violão para a caixa e me diz "o que vamos fazer agora...??". Olha para a pasta de material gráfico e começa a passear com o dedo apontando, "isso... Isso..." Enquanto ele aponta, eu nomeio, até que pára na tinta. Retira a tinta da caixa e procura o pincel sem sucesso. Ajudo-o, digo que parece realmente que o pincel não está na caixa e digo a ele que, na falta do pincel, poderemos pintar com o dedo (realmente acho estranho, uma vez que a caixa não foi mexida e já havíamos pintado antes).

Ele pega uma caixinha de tinta e vai até a pia. Lá, coloca cuidadosamente o dedo e começa a passar pela cuba da pia e me diz: "Oh". Digo que ele está me sinalizando, que dá sim para pintar com o dedo. Ele lava as mãos, volta para a mesa e pede que eu pegue os papéis, um para ele e um para mim. Divide as tintas, pergunta quais cores eu quero, escolho uma e o deixo escolher as demais. Abre as caixinhas de tinta, olha atentamente para elas, estica os dedos, mas receia em mergulhá-los sobre as tintas, aproxima e afasta os dedos dos potes algumas vezes. Olha para mim e diz: "vai você!..." Sinto que Igor queria ser acompanhado... Não pretendendo titubear com o 
convite, mas, com cuidado, mergulho o dedo na tinta e pinto no meu papel um sol, desbravando aquele movimento. Em seguida, ele mergulha o dedo na tinta e se delicia. Igor aproveita para pintar todo o papel com as mãos inteiras, misturando várias tintas, convidando-me para seu deleite. Limito-me a pintar com os dedos e ele continua misturando as tintas e percebendo a mistura de cores. Vai até a pia com o pote vermelho, derrama o pouco que restava da tinta com a água corrente e canta uma música "catchup vermelho, catchup vermelho... Veio um caminhão verde, veio um caminhão verde ih... Coitadinho do tomatinho..." (insinuando na música que o tomatinho era atropelado). Lava todo o potinho e volta para a mesa. Pega outro e vai até a pia e, assim, continua até o final da sessão até terminar de lavar os potinhos azul e vermelho.

\section{Comentários}

Logo no inicio da sessão, Igor fala do espaço que precisa e que se sente tranquilizado quando sabe que pode ter. Talvez do que Igor também precise, nesse momento, não é somente um espaço qualquer, mas sim aquele que possibilite desenvolvimento e que, para tanto, seja cuidadoso o suficiente, o que implica oferecimento de continência e discriminação.

\section{Entrevista Clínica 7}

Igor corre para dentro da sala, na minha frente, como de costume, quando o chamo para entrar. Entro na sala, em seguida, comunico a ausência dele chamando pelo seu nome e perguntando onde ele está. Ele faz alguns barulhos com a cadeira e depois sai debaixo da mesa com um "ah!". Vai até a caixa e procura as bolinhas e, diante da dificuldade de encontrá-las, diz "sumiu". Ajudo-o, mexo na caixa e encontro as bolinhas. De frente um para o outro, jogamos com os pés para fazermos gols. Depois, faz algumas tentativas de cestas na pia. Sobe na escada de dois degraus e, diante do armário, joga as bolinhas sobre ele para que fiquem paradas lá em cima. Algumas vezes, eu pego as bolinhas que caem no chão, mas outras ele pega sem que desapareçamos um para o outro. 
Deixa as bolinhas, vai até a caixa e pede para brincarmos de tinta. Ele começa com o pincel fazendo um risco e depois diz que é minha vez de pintar. Passo novamente o pincel para ele e ele começa a despejar um pouco dos conteúdos do restante das tintas no papel, misturando as cores. Depois vai até a pia e pede para que eu leve até ele os potes. Levo um de cada vez, a cada pote ele tira o restante da tinta e o lava até que fique transparente. Assim faz até terminar a sessão.

\section{Comentários}

Parece cada vez mais evidente que Igor chega com urgência à sessão, comunica-me que tem pressa de entrar como se estivesse atrasado, mas, aos poucos, compreendendo que Igor parece ter sofrido um atraso. Um atraso no atendimento a suas necessidades: de ser olhado, encontrado, acolhido, contido.

Ao refletir sobre a pressa do meu paciente, dou-me conta de que também temos, eu e ele, um tempo que é curto e que talvez devamos ter pressa para fazer o máximo possível em pouco tempo disponível.

As tentativas de lidar com seus conflitos e angústias são muitas, em especial, destacamos a introjeção de um objeto bom. Igor me conta, assim que a sessão inicia, que ele precisa de alguém que o procure e o encontre. E, cada vez que nos separamos, o jogo é repetido. Se quem procura demora a encontrar, a sensação é de que o que precisa ser encontrado some, como na busca de objetos dentro da caixa com a primeira sensação de que não estão lá.

Igor me conta, nessa sua história de acidentes traumáticos, que precisa introjetar confiança, uma segurança íntima no bom objeto que vai estar presente ainda que ausente e que, assim, pode segurar, acolher e conter. 
Igor corre apressado à minha frente e entra na sala. Esconde-se embaixo da mesa e, quando eu entro, chamo por ele: "Igor, onde é que você está...?! Parece que te vi entrar por aqui... Nossa, mas achei que ele estivesse aqui... (digo pensando em voz alta) Afinal ele entrou tão apressado à minha frente... (continuo procurando). Onde será que você está...?!". Igor sai debaixo da mesa e digo: "Ah! Você está aí... Que bom que você apareceu..." Nesse momento, percebo minha disponibilidade em estar com ele e o percebo também bastante receptivo. Ele vai sorrindo até a caixa, abre o cadeado, a tampa e mexe nos brinquedos, pergunta-me: "do que vamos brincar hoje...?" Digo: "do que será que podemos brincar..." acompanhando-o na escolha. Pega as bolinhas e começamos a jogar um para o outro até que ele bate a perna em um móvel. Imediatamente ele agacha, demonstra dor, coloca as mãos sobre a perna e no tempo de ir ao seu encontro, ele se levanta, vai até a caixa, pega o telefone e o coloca sobre a mesa segurando com uma das mãos a perna - tudo muito rápido. Fico atenta a esse movimento instantâneo: dor-telefone; seria um chamamento? Agacho até ele pergunto o que houve e ele me diz que bateu no armário, coloco as mãos sobre as mãos dele, fricciono um pouco e digo que parece que doeu muito, ele se levanta e logo está pronto para brincar.

Sobe na escada de dois degraus, arrisca algumas jogadas de bola para cima do armário e, em uma delas, quando a bolinha cai, ele se esconde. Procuro-o e ele logo aparece. Diz que é a minha vez agora de esconder. Apaga a luz, diz que vai contar até dez, sai da sala e eu me escondo. Ele entra na sala escura, acende a luz, diz: "Ué! Cadê ela?!" - procura e não me acha, procura e me acha. Ele diz: "Agora é minha vez", eu pergunto "conto até dez?", ele diz: "você sai, apaga a luz e conta até dez". Assim eu faço.

Em um momento, escondo-me debaixo da maca e percebo que ele pára de me procurar, sobe na maca e deita sobre ela. Aguardo um pouco, saio devagar debaixo da maca e o vejo deitado de costas, com as mãos no rosto sobre a maca, encostado na parede. Chego perto e chamo por ele, pergunto se ele está me ouvindo, se está acordado, digo que estou ali, ele sorri e se levanta. 
Igor quer se esconder no armário, abre a porta e faz tentativas de entrar sem sucesso. Digo que esconder no armário deve ser bom porque dá a sensação de estar protegido, é apertadinho... (enquanto ainda tenta entrar). Ele pede para que eu feche a porta do armário, mas a porta fica entreaberta. Ele sai e novamente tenta se ajeitar no nicho do armário de forma que ele caiba, fica todo encolhido, me pede para fechar a porta do armário enquanto ele segura uma fresta com a mão, e para que eu saia, para que eu conte até dez e o procure. Saio e apago a luz, sinto que ele se assusta um pouco, mas, quando digo em voz alta que estou saindo e que vou começar a contagem para procurá-lo, sinto também que ele conseguirá ficar "preso". Conto até dez e entro na sala acendendo a luz. Começo a procurá-lo e nada de o encontrar. Procuro por todos os lugares onde ele costuma estar e vou dizendo em voz alta que ele não está e que já estou começando a ficar preocupada e começando a me sentir sozinha. Vou até o armário, abro uma das portas e digo que lá ele também não está. Até que ouço um barulho. Repito o som na porta do armário que está ao meu lado e, novamente, outro som vem de dentro do armário, até que abro e ele finge não ser visto. Digo que acho estranho porque ouvi um barulho. Quando digo "e agora, o que vou fazer... Não encontro, já procurei por todos os lados!" um novo barulho surge no armário e finalmente lgor pode ser encontrado.

Ele sai do armário, vai até a caixa, pega as bolinhas e vai até a pia. Pergunta-me se pode molhar e digo que sim. Molha uma das bolinhas e começa a jogar sabão líquido sobre ela e diz que é catchup. Diz que é para eu molhar a minha e fazer o mesmo e que já vai dar o nosso horário. Digo que ainda temos tempo, mas que parece que ele está preocupado com o tempo, talvez porque ele goste de estar ali e queira ficar mais, uma vez se sente compreendido. Ele me olha e diz que ele queria ficar muito, muito, muito, muito tempo.

Ao jogar o sabão líquido, molhar e apertar as bolinhas, elas parecem esponjas e produzem muita espuma. $O$ interesse dele parecia produzir muitas espumas, mas antes, despejar todo o sabão líquido na bolinha até acabar o frasco. Pensei se deveria interditá-lo e optei por não fazê-lo. Ele enxaguou superficialmente a bolinha e queria jogar pela sala e, nesse momento, digo a ele que, para que possamos brincar com elas 
novamente, precisamos tirar-Ihes todo sabão e espuma. Passamos o restante da sessão enxaguando as bolinhas e apertando para que o excesso de sabão saísse, livrando toda a espuma, que ele parecia achar muito interessante quando quase transbordava o ralo e deixávamos escorrer. Encerramos a sessão, enxugamos as bolinhas que já estavam menos pesadas e guardamo-las na caixa que, dessa vez, ele fez questão de fechar.

\section{Comentários}

O movimento de Igor nessa sessão, quando bate a perna e pega o telefone, assemelha-se a um chamamento de socorro à suas necessidades. A falta do bom objeto internalizado, provavelmente, está ligada às dificuldade na espera, ao reconhecimento da minha presença e disponibilidade de estar ali ao seu lado. Igor parece também não ter a onipotência necessária para aguentar essa espera, para estar só até que eu chegue até ele e o acolha - o seio está ali e, ainda sim, não existe a ilusão do seio antes de ele chamar.

Nesse sentido, o movimento seguinte de esconder e procurar também sugere poder esperar e poder não ter. Poderia ser um princípio de desenvolvimento? Talvez uma tentativa de lidar com o conflito. E tal como em outras sessões anteriores, quando Igor se aproxima de situações mais elaborativas, também se aproxima da maca, o que nos sugere uma tentativa de se reportar à cirurgia.

Novamente, Igor tenta, por meio da brincadeira, contar-me sua história e lidar com seu conflito. Como no jogo do carretel de Freud, o sumir e voltar tem um significado importante, bem como, ficar "preso" no armário. Poder sentir-se contido pelo nicho do armário, em um lugar apertadinho e quente, pode ser uma condição de estar preso, mas um preso que o liberta. Estar só na presença de alguém possibilita que Igor, aos poucos, liberte-se, em outras palavras, desenvolva-se. 
Somado à sua condição de uma tentativa de trabalho interno, Igor também fala do vínculo na sessão: encontrar e não me encontrar e estar só também tem relação com o nosso tempo que possui um limite definido para acabar.

Igor tanto sabe do término que, ao final da sessão, usa todo o sabão líquido do frasco, até o fim, esgotando-o o máximo que pode, assim como tira das sessões tudo o que é capaz: suga, absorve, produz. Depois, enxágua a bolinha e livra a espuma comunicando, de algum modo, o corte dado pela realidade - talvez de que as sessões terão um término, um fim.

\section{Entrevista Clínica 9}

Igor entra correndo pelo corredor até a sala. Entro em seguida, chamo pelo seu nome e o vejo escondido embaixo da maca, ele cruza o olhar com o meu e, logo, dá-se por encontrado saindo debaixo da maca. Vai em direção à caixa e procura os carros e o trilho do trem. Ajudo-o a encontrar os objetos, ele tira também da caixa os caminhões e o avião. Procura a cerca, coloca na frente do trilho, depois diz que não precisa e joga de volta na caixa.

Pede para que eu tire o computador da mesa e digo que podemos afastá-lo um pouco mais, mas não tirá-lo, ele se dá por satisfeito. Segura um lado do trilho e eu o outro, faz os carros passarem em dupla pelo trilho e diz: " ih, matou eu e matou você também"... Penso na fala de Igor, na colisão e questiono: "mas o que aconteceu?". Ele diz: "tava passando o trem..." e sua fala exprime pesar. Digo que isso me faz lembrar algo que está acontecendo com a gente, de que não temos muito tempo juntos, mas apenas algumas sessões e que logo teremos que nos separar. Ele não demonstra reação à minha fala.

Também digo que me admira que os carros queiram atravessar bem na hora em que o trem está passando e que isso acabará, sim, em acidente, porque não existe sinal nenhum indicando que é a vez do trem ou dos carros. Ele vai até a caixa e 
procura um sinal e não o encontra. Então, proponho, após observá-lo em sua busca sem sucesso: "que tal nos fazermos um semáforo com isso aqui?" - tirando os pinos de montar. "Boa idéia!" - ele diz entusiasmado e completa falando que não sabe fazer um sinal. Vou montando uns pinos para o sinal, digo que há as cores da sinalização: vermelho, amarelo e verde; enquanto isso, ele diz que vai fazer um trem bem grande e que é para eu fazer vários sinais. Faço três e ele monta o trem enorme, juntando todos os pinos restantes nesse trem que começa não caber sobre a mesa.

Igor tenta fazer uma curva com o trem de pinos sobre a mesa, o trem começa a desmontar e ele começa ficar impaciente. Digo que o trem precisa ficar reto para que não desmonte e tento ajudá-lo, enquanto o trem começa a desmontar, porque ele insiste que caiba na mesa fazendo a curva. Diz que não quer mais, desmonta tudo, pino por pino, fica bravo e começa jogar agressivamente as peças dentro da caixa. Digo que ele fica muito bravo quando as coisas não saem do jeito que ele quer ou imagina - o que sinto que não alivia em nada sua revolta contra os pinos e contra mim. Digo também que, provavelmente, ele deve ter ficado triste quando falei que nosso tempo juntos logo chegará ao fim. Igor pega as bolas dentro da caixa e pede para jogarmos. Esconde-se, assim, que a bola cai e, quando vou procurá-lo, encontro-o. Jogamos mais um pouco e ele diz que é a minha vez de esconder, quando vai me procurar embaixo da mesa, joga a bola propositadamente em minha direção e acerta o meu rosto. Digo que isso não pode acontecer, mas que entendo que ele ainda esteja bravo...

Ele vai até a caixa e sentamos à mesa. Pega os carros, o caminhão, o avião, o trem (ele chama de trem, mas é o trilho feito com uma mini escada) e me pede para que eu pegue os animais. Vou colocando os animais em cima da mesa, enquanto ele os coloca todos dentro da carroceria do caminhão, anda com ele até o "trem", passa sobre o trilho. Depois me pergunta se podemos fazer uma ponte e faz os carros passarem por debaixo do caminhão dizendo que é a ponte, do meu lado (onde está o meu carro) há o sol e do lado dele (do carro dele) existe a sombra. Nesse trânsito, os carros passam de lá para cá e daqui para lá e atravessam a ponte, mas o avião não passa, esbarra na altura do caminhão. 


\section{Comentários}

A cada sessão Igor e eu nos encontramos com maior facilidade e mais rapidez. Desde as primeiras intervenções, até este momento, houve uma mudança no nosso encontro. Saindo de seu "esconderijo", com rapidez, sinto Igor mais disponível, sem precisar de tantos elementos sensoriais para que pudesse ser achado e acalmado. Igor precisa do olhar e logo que isso acontece, ele reconhece.

Talvez, esse reconhecimento do encontro e o significado de estar junto tenham sido fatores mobilizadores de angústia em relação ao término das sessões. Essa é uma questão delicada, para o próprio terapeuta, quando este precisa lidar com um limite real, apesar de todo desejo seu e da necessidade do próprio paciente. Pergunto-me se o encerramento, próximo de acontecer, não me fez antecipar ainda mais uma conversa que Igor não estava disposto a falar. O carro passa e o trem atropela, evidenciando uma colisão. Igor sinaliza que eu e ele colidimos. Falar do término em um momento em que Igor precisava da minha disponilidade parece ter sido um atropelo. Seria minha angústia de separar-me de Igor o fator mobilizador da tragédia antecipada? O tempotrem não espera, urge. Digo a Igor sobre um sinalizador para que os acidentes tenham chance de serem evitados.

Quando trago a realidade para Igor, ele fica bravo. É certo que ele, provavelmente, queria aproveitar o tempo que tínhamos e que talvez eu tenha limitado o espaço.

Ao buscar vida, entrando sempre correndo as sessões, Igor sabe que existe um limite de tempo para as sessões - limite do qual ele protesta e, algumas vezes, nega. Igor corre e, nessa corrida em querer aproveitar, atira-se, sem proteção. Estaria Igor operando em uma relação adesiva? Não é de se admirar, uma vez que entre o sol dos dias e a sombra das noites, Igor tenha tanta necessidade dos dias... 


\section{Entrevista Clínica 10}

Igor corre pelo corredor até a sala, chega à minha frente e, em um movimento repetitivo, esconde-se. Entro e logo o encontro. Ele sai debaixo da mesa, vai até sua caixa e remexe. Tira as bolinhas, olha e prefere guardá-las, em seguida pega os carros, tira-os um a um e também guarda-os, pega as massinhas, mas também prefere não usá-las. Fico com a impressão de que renuncia aos brinquedos aos quais ele já tem uma história. Examina outros brinquedos e, com a tesoura em mãos, pega o telefone e corta o fio. Falo em voz alta que o telefone está agora com o fio cortado e pergunto "o que será que aconteceu?". Igor deixa o telefone, pega as bolinhas, vai até a pia, abre a torneira e molha as bolinhas, pede para que eu vá até ele e me dá uma delas. Começa a encharcar a bolinha e jogar sabão liquido sobre ela, faço o mesmo, até começarmos a brincar quem poderia fazer mais espuma, apertando as bolinhas sem enxaguá-las, apenas deixando que a espuma inundasse a pia. A expressão de lgor era de contentamento, sempre disposto a fazer mais espumas apertando a bolinha com as mãos e evitando que a água da torneira levasse a espuma embora. A cada sinal de que as bolinhas não produziriam espumas ele despejava sabão liquido em abundância nas bolinhas para que as espumas não cessassem. Vez ou outra, abria a torneira e via a espuma se desfazer, escorrendo pia a fora e prontamente apertava a bolinha para produzir mais espumas. Igor sorria.

A brincadeira de produzir espumas durou até o final da sessão. Nos minutos finais, enxaguamos as bolinhas, enxugamos e guardamos dentro da caixa. Igor lamentou o final da sessão.

\section{Comentários}

Não por acaso Igor corta o fio do telefone, o corte-desligamento está sendo por ele comunicado e processado. Poderia ter havido uma interpretação quase óbvia, mas no momento o campo me parecia já saturado demais. Igor já estava tendo que lidar com muitas coisas, além de suas próprias questões, estava tendo que lidar com a 
nossa separação. Questiono-me se o término não seria mais uma vivência traumática, mas suponho que estar com ele envolveu mais benefícios. Ao questioná-lo sobre o que aconteceu, Igor, em seguida, insere uma brincadeira: encharca as bolinhas para produzir, inesgotavelmente, espumas. Muitas espumas até quando pudesse. Contente e satisfeito, não se cansava em ver a espuma cobrir toda a pia, a espuma se desfazia quando a água escoria pela pia e ele produzia mais.

Igor parecia querer aproveitar o máximo o tempo da sessão, que poderia ser para ele inesgotável. Talvez para ele fosse inesgotável se não houvesse o dado de realidade. Fazer - desfazer; prazer - desprazer... Igor estava tentando lidar com mais um conflito...

\section{Entrevista Clínica 11}

Igor entra na sala, vai direto à caixa, abre-a, pega o telefone e, em seguida, a tesoura. Pergunta-me sobre o fio do telefone (cortado por ele em sessão anterior), pega o fio cortado dentro da caixa enquanto faz freneticamente o movimento de abrir e fechar a tesoura. Corta o fio em vários pedaços, diz: "tchau, tchau" e repito sua fala, "tchau, tchau", compreendendo seu corte-desligamento. Ele novamente diz: "tchau, tchau" e coloca os pedaços do fio de volta na caixa.

Pede-me para brincarmos com as bolinhas na pia e com o sabão líquido igual ontem (referindo-se à semana anterior), diz: "vamos fazer igual ontem até encher tudo?" Pega o frasco do sabão líquido e vê que está vazio, faz cara de quem não gostou, franze as sobrancelhas, fica bravo. Fico aguardando sua reação antes de propor a ele uma alternativa. Ele diz: "e agora? Ah, assim não dá...", lamentando-se.

Depois de alguma espera, digo que podemos, se ele quiser, tentar pegar o sabão liquido de outro lugar e ele prontamente aceita. Vamos juntos à sala ao lado com o frasco em mãos. Encho um pouco o frasco com o líquido e pergunto se está bom, ele responde que sim. Voltamos à sala e começamos a fazer espuma enquanto ele 
aguardava ansioso por ver o ralo encher com as espumas que saíam das bolinhas e escorriam pela pia junto da água. Igor estava ansioso para que o ralo enchesse e as espumas saíssem para fora da grelha. Mas, como não enchemos todo o frasco, as espumas não eram tão abundantes. Ele espera e, então, propõe brincarmos de outra coisa.

Vai até a caixa e tira os carrinhos. Brincamos um pouco com os carros meu e dele trombando e ora eu jogava o meu carrinho até ele, ora ele jogava o dele até mim. Pega o caminhão e procura o trem, pede para eu pegar os pinos, começa a montar o trem e logo desiste, dizendo "ah, não" devolvendo-os à caixa. Apenas digo que parece que ele desistiu de brincar com o que tinha em mente. Ele pega novamente as bolinhas e me chama para irmos até a pia novamente.

Diz-me, apertando as bolinhas, "ih... logo, logo vai acabar, o tempo vai acabar", digo que sim e que isso realmente parece muito ruim, ele concorda apenas dizendo que sim, esvaziando o frasco de sabão líquido que acaba rapidamente. Mais um tempo se passa nessa atividade de apertar as bolinhas e fazer espumas, deixar a água levar as espumas e esperar que elas se acumulem no ralo. A espuma não sobe no ralo como era o desejo de Igor. Enquanto ele torce para que isso aconteça, estamos os dois agachados perto do ralo enquanto ele joga água, observando o acúmulo de espuma. Digo que realmente é uma pena, pois o frasco não estava tão cheio quanto ele queria e capaz de produzir muitas espumas quanto ele desejava. Nessa hora, tenho em mente que estou dizendo a ele do sabão líquido como a relação entre nós dois e do término do nosso encontro. Igor fica mais um tempo ali, enchendo o frasco, despejando a água pelo ralo e apertando as bolinhas para fazer espumas. Joga a bolinha no chão e, com esse movimento, molha a sala e interdito. Apertamos mais um pouco a espuma, deixamos as bolinhas na pia para secar. Ele volta à mesa.

Diz-me que quer fazer um trilho bem grande para que caibam os carros, o avião e o caminhão e pega o durex. Com a minha ajuda, ele gruda o durex sobre a mesa de um lado e de outro, até que a forma pareça mais com um caminho do que com um trilho. Faz esse caminho bem largo de forma que caibam dentro dele os carros, o 
caminhão e o avião, pinta o trilho com canetinha colorida até que termina a nossa sessão.

\section{Comentários}

O início da sessão é marcado com um dado real que fere o desejo de lgor: o de que tivéssemos um tempo inesgotável juntos. Não ter sabão líquido naquele momento era quase dizer que não havia nada que pudesse ser oferecido a ele, algo concreto e real demais, além de abreviar nosso tempo. Igor fica bravo, não sem razão. A busca por algo que eu pudesse oferecer, ainda que não fosse o tanto que ele gostaria, mas que fosse do desejo dele significou para nós que tínhamos algum tempinho ainda juntos que poderíamos aproveitar. Nessa medida, Igor estava tendo que lidar com um novo conflito que, talvez, fugisse da sua queixa manifesta. Todavia, lidar com o desligamento fazia parte do contexto e, sob outro ponto de vista, também dizia a respeito da minha relação com lgor.

Quando Igor deixa de fazer espumas e propõe fazermos um trilho, penso nos seus desenhos e estórias do início dos atendimentos, logo quando chegou para as sessões. As estórias falavam de trens que colidiam com caminhão, com uma ponte, com um carro, explodiam. Penso que lgor falava novamente desses elementos na sessão, elementos que, no seu psiquismo, estavam fazendo um movimento novo, um trilho, que mais parecia um caminho, onde todos estes poderiam ter passagem, sem se confrontarem, sem que explodissem.

\section{Entrevista Clínica 12}

Igor entra correndo pela porta e vai até sua caixa. Dessa vez, não se esconde, não tenho que procurá-lo. Penso comigo, Igor já está ali, uma boa sensação me invade. Digo a ele que, primeiramente, gostaria que ele fizesse para mim alguns desenhos 
antes de brincarmos (desenhos esses que fazem parte do encerramento das sessões). Com certa resistência (por adiar seu ímpeto a brincar), ele concorda.

Igor tem dificuldade em se concentrar nos desenhos. Não se senta à mesa para desenhá-los, faz às pressas como quem realmente não quer perder tempo. Igor sabe que é nossa última sessão juntos e parece que, sendo assim, conclui os desenhos com rapidez. Igor quer brincar, está ávido, como no nosso primeiro encontro.

Sua escolha de brincadeiras, porém, assemelha-se aos encontros anteriores. Brincamos de bola, jogando um para o outro e também em cima do armário. Depois pega os animais e os carros e, desta vez, em cima da maca, vamos brincar. Com o durex, faz uma marcação na maca, como se fosse um caminho largo, pergunto o que é e ele diz que é um trilho, os carros passam juntos. Os carros vão e voltam, apostam corrida. Ficam enfileirados seguidos pelo avião e pelo caminhão. Depois enche a carreta do caminhão de animais e se diverte com isso, ora derrubando os animais, ora enfileirando-os para que o caminhão venha e os atropele. Penso em um caminhão cheio de animais - vivos. Embora sejam ora derrubados, ora atropelados, agora os animais é que roubam a cena. Igor, embora sofra intempéries, está vivo tal como os animais da minha fantasia.

Ao final da sessão, Igor pega as bolinhas e vai até a pia. Lá molha as bolinhas, enche de sabonete liquido e as aperta provocando espuma. Falamos sobre nosso último encontro, ele diz que gosta de estar ali e de poder brincar e que gostaria de voltar. Brincamos até o finalzinho da sessão com a espuma e combinamos de nos encontrar mais um dia para nos despedirmos. Encerramos a sessão.

\section{Comentários}

Igor fez os desenhos com maior desenvolvimento do que o do início das sessões (anexo 2) e suas estórias, embora parecessem iguais, continham algo diferente. Enquanto Igor narrava as estórias, algumas palavras eram produzidas por sílabas. Ele 
me acompanha bem de perto, observava-me escrever sua narrativa até o fim. As palavras pareciam estar no centro de sua atenção. Pede-me a caneta e se arrisca a escrever algumas delas. Escreve um emaranhado de letras agrupadas, formando palavras desconexas. Depois me pede para escrevê-las para que depois ele pudesse as copiar - moto, caminhão e trem estavam entre elas -. Ao final, numa folha separada Igor se arrisca a escrever sozinho, escreve seu nome.

Apesar de todo o movimento repetido de Igor, há algo que busca transformação. A inserção de novos elementos à cena, como os animais que passam pelo caminho que Igor e eu construímos nessa sessão, traz a esperança de outra ordem frente ao caos apresentado pela repetição contínua. Caos, este, visivelmente modificado pela apresentação de seus desenhos do início e do fim.

Ao final da sessão, Igor pode retomar a brincadeira das bolinhas e espumas e comunicar novamente o aproveitamento do nosso encontro, que seja eterno enquanto durar.

\section{Entrevista Final com os Pais}

Pai e mãe vêm para entrevista final. Começam a contar, com cumplicidade, como está Igor. Vejo que os dois falam em melhor sintonia. Contam que Igor está bastante levado, que teima para tomar banho e que obedece à mãe sempre na última hora (antes de a mãe perder por completo a paciência). Penso que não há nada na fala dos pais, a respeito da relação deles com Igor e de lgor com o restante do mundo, neste momento, diferente da queixa de pais de filhos que não tiveram vivências traumáticas dessa natureza. Digo isso a eles, porque se reportavam a Igor como uma criança especial, e os acolho em suas tentativas e em angústias de educá-lo.

A mãe conta um dado curioso que vem chamando a atenção dela e com o qual ela tem se intrigado: de que em algumas das falas de Igor aparece o tema da morte. A mãe fala, em tom preocupado, que também ele mencionara sobre a morte dela. A mãe 
me questiona o que isso pode ser e, diante desse questionamento e da nossa conversa no momento anterior a este, digo a ela que isso pode ter muito mais a ver com o tema de perdas em geral do que com a morte dela, concretamente. A mãe engasga, fica vermelha, leva as mãos à boca contendo a tosse e o engasgo, emocionada ela abaixa a cabeça. O pai bate em suas costas e pergunta o que houve e me diz: "doutora, acho que foi alguma coisa que a senhora falou". Aponto que sim com a cabeça e o pai voltase à mãe perguntando o que foi e dizendo para que ela conversasse comigo. Pergunto a ela em tom brando (mais apontando do que propriamente questionando): "com o que será que você se emocionou, hein...?!". A mãe leva as mãos ao rosto, enxuga lágrimas dos olhos e diz que, quando eu mencionei a palavra perda, ela lembrou-se de Igor, que ele já não era mais seu bebê. Ela completa dizendo que hoje ele é uma criança levada e sapeca, que interage, que conversa, que brinca e que tem amigos. Muito diferente da criança que começou os atendimentos que não conseguia vestir uma roupa sozinho e que não tinha iniciativa.

Digo que o bebê dela finalmente cresceu e que, parece-me, que já não é tão dependente dela como antes. E que isso é ótimo; mas, ao mesmo tempo difícil, porque a idéia de termos um bebê que não cresce é sedutora e que entendo que a palavra perda tenha mobilizado nela muitas coisas, porque, provavelmente, estão vivendo uma fase de muitas mudanças, e também com muitos ganhos.

A mãe conta, com satisfação, que, dentro de casa, Igor é o primeiro a acordar e diz que ele não vai ficar dormindo não, que ele vai é brincar. Já veste a roupa, calça seu calçado, ele mesmo come algo por conta própria e vai andar de bicicleta e que isso é muito novo para ela, porque ele dependia dela para tudo. A mãe faz uma nítida associação entre esse desenvolvimento de Igor e o início das sessões.

Digo também que, além de tudo isso, nós estamos conversando para encerrar esse processo e que esse desenvolvimento de Igor foi possível por vários motivos (a correção da cardiopatia, as intervenções psicoterápicas), mas também foi possível porque eles tiveram condições para ir atrás dos recursos disponíveis para auxiliar o filho. 
Converso com os pais sobre a necessidade de lgor ingressar em um acompanhamento psicológico e sobre a disponibilidade de uma pessoa para atendê-lo. Os pais agradecem, dizem que vão esperar e ver como Igor reagirá sem ajuda, pois eles não têm ninguém para levar o menino a um atendimento e que a maneira como as coisas aconteceram deu certo, porque, com o acidente do pai e seu afastamento do serviço, foi possível trazer Igor às sessões.

Já, no final do tempo, eu agradeço à mãe e ao pai e ambos também me agradecem muito. A mãe volta a chorar e me abraça calorosamente, até deixar a sala. Os atendimentos com Igor chegam ao fim.

É possível observar alguns desdobramentos do traumático em lgor; nas sessões, ele não perde tempo em tentar narrar sua história e lidar com alguns de seus conflitos que nos parecem centrais em seu desenvolvimento. A série de acidentes trágicos, presente nas sessões, a busca de um espaço de continência, o desejo de serem encontrados aspectos centrais de sua pequena história, parece referir a toda uma série de experiências vividas que precisariam de um espaço de simbolização. A cena que os pais contam de uma queda ou de uma falta de continência, no início de sua vida, além de crucial, é também emblemática. $O$ baixíssimo peso, a fala tardia e uma doença do coração arrematam um início de existência infeliz. Em seguida, eis que surge uma operação.

A operação e os dias de internação, em unidade de terapia intensiva (UTI), funcionam como elementos traumáticos, disparando e acionando uma série de defesas no psiquismo infantil frente à ameaça de desamparo. Acreditamos que a internação, em unidade de terapia intensiva, tenha reativado enormemente suas angústias e que tenha tido intensidade o bastante para lhe provocar um excesso de estímulos. Por tais razões, também cremos que essa vivência poderia contribuir para o congelamento de suas capacidades simbólicas.

O paradoxo da operação cardíaca é que, apesar de uma condição extremamente aversiva, invasiva e, sim, traumática, ela dá condição à vida. Talvez, no caso de Igor, ele começou realmente a viver depois da operação, uma vez que, além das 
necessidades físicas concretas que the foram atendidas, também suas necessidades emocionais encontraram um lugar para serem olhadas, cuidadas e contidas.

As intervenções psicanalíticas com Igor tiveram como ênfase o oferecimento de um espaço em que ele pudesse expressar suas angústias e conflitos por meio do brincar. Esse espaço privilegiou o acolhimento e o holding (WINNICOTT, 1990), bem como o continente com rêverie (BION, 2004). Sob esse aspecto, os elementos pouco integrados referentes à hospitalização ficaram evidentes. Esses elementos desconexos e fragmentados também puderam ser notados nas intervenções com Sofia, uma segunda criança atendida por nós. As sessões com Sofia seguiram os mesmos princípios e técnicas privilegiados no atendimento com lgor, que descreveremos sucintamente, a seguir, pois servirá de modelo para ampliarmos a nossa discussão.

Sofia foi trazida às intervenções psicanalíticas pela mãe, o pai não pôde acompanhá-la devido a circunstâncias de trabalho. Sofia tem quase cinco anos, a mãe tem vinte e dois e o pai é dez anos mais velho. A cardiopatia de Sofia foi descoberta a alguns poucos meses da operação e recebida com muita apreensão pela mãe que também é portadora de cardiopatia congênita e perdeu um irmão, ainda bebê, também cardiopata. A mãe tentou parto normal, mas Sofia nasceu de cesariana com quarenta e duas semanas, a mãe sofreu parada cardíaca, ficou na UTI durante três dias do pósparto, mesmo lá recebeu Sofia e amamentou. Enquanto a mãe me relatava alguns fatos da história de Sofia, eu tinha a sensação que mãe e filha se misturavam e me esforçava para entender quando a mãe relatava aspectos dela ou da filha.

Apesar de um parto relativamente tardio e de um histórico de cardiopatia, Sofia não teve atrasos no desenvolvimento, foi relativamente precoce para andar, falar e tirar as fraldas. Dentre um relato e outro a mãe conta que Sofia, invariavelmente, vomita, se agita, tem febre e dores de cabeça quando está ansiosa, à espera de algo ou situações novas. A mãe diz, quando questionada, que não foi conversado com Sofia sobre a operação, temendo que houvesse uma reação muito negativa por parte dela no préoperatório, mas que a menina ficou mais irritada e agressiva após a cirurgia. Além desses aspectos, ela também menciona que não poderá afirmar que Sofia virá para as 
sessões facilmente, uma vez que a menina está com aversão de entrar no hospital ou no ambulatório.

Sofia vem receosa para o primeiro encontro, mas logo nos seguintes aparenta estar bem amistosa e afetuosa. É esperta, tem uma vida rica de fantasia e associações. $\mathrm{Na}$ primeira sessão faz os desenhos (anexo 3) e conta a seguinte estória: "são montanhas e um monte de casa, minha mãe e meu pai não tava aqui porque nos tava na painha (prainha). Meu pai minha mãe tavam viajando eu tava com minha vó na painha, eu tava com sede lá com minha vó na painha e não tinha água pra beber só para nadar. Minha mãe caiu dentro do rio e de novo, de novo, de novo um monte de vezes. Eu tava suando sem água", Sofia diz que acabou a estória, que não quer desenhar mais e que está com sede. Minha primeira lembrança é do atendimento a crianças cardiopatas, isso porque a sede é característica dessas crianças quando recém operadas. No pós-operatório, a ingestão de líquidos é rigorosamente controlada a um volume mínimo para não haver consequências na operação. Com base no conceito de insaturação em construir sentidos (FERRO, 1995), além dessa lembrança, penso que Sofia fala de sede, de escassez e de uma mãe que está ao redor de água em abundância e que cai no rio muitas vezes. Questiono-me qual a comunicação de Sofia.

Nas sessões seguintes, ela usa muito a tesoura, barbante e cola, bem como as tintas. Brinca que vai me consultar em muitas sessões. Em uma delas, ela entra, sentase à mesa e diz que quer brincar de médico. Abre a gaveta, onde estão guardados os blocos de receituários médicos, no mesmo instante me diz: "sabia que estou grávida... De quatro meses?" (justamente naquela semana eu completava quatro meses de gravidez). Digo: "Ah, é... E me diga, o que a traz ao hospital?" (insinuando o início de um jogo). "É que sabe meu bebê já vai nascer..." Eu digo: "ah, entendo..." (acolhendo a fantasia, sem entender direito aonde ela nos levaria) e continuo: "e como é que você está?", ela balança a cabeça "bem".

Sofia pega caneta, blocos médicos, carimbo, faz alguns rabiscos e letras, sentese importante com os blocos de papel. Diz que agora ela vai me examinar, pede para 
que eu deite na maca, nesse encontro ela me olha, diz que está tudo bem e que posso me levantar.

Volta-se para a caixa de brinquedos e vai retirando os materiais com os quais pretende brincar: tinta, papel, régua, pincel, cola, canetinha. Pega uma nova folha para mim e uma para ela, me pede para fazer igual: divide a folha com o lápis fazendo dois riscos na horizontal e três na vertical, começa a fazer um desenho em um dos campos, abaixo da metade da folha, com forma desconhecida e contorcida. Ela diz que o desenho dela é uma cobra. Pergunta-me se tenho medo. Digo que se for uma cobra brava eu tenho medo sim. Ela diz que é brava e pergunto o porquê, ela diz que tiraram o bebê dela. Digo que ela tem razão, então, de estar brava, associo com bebês roubados, com conteúdos lhe sendo tirados, com castração e com sua cirurgia.

Sofia pinta o conteúdo do desenho em um tom acinzentado, o desenho permanece, mas logo ela pega todas as cores e começa a pintar todo o desenho. Encanta-se com a mistura que produz nos potes, depois despeja a tinta preta no papel e pergunta-me se pode pôr a mão. Digo que sim, e ela delicadamente vai espalhando, com a palma da mão, a tinta no papel. Em seguida, lava a mão e volta para o papel. Nesse instante já não há mais o desenho da cobra, nem o pouco colorido de sua produção anterior, pergunto a ela o que aconteceu com aquele desenho que ficou todo preto... Sofia me diz que a cobra se assustou...

Sofia tem conteúdos demais à espera de um significado, almejando serem elaborados e representados, elementos beta que necessitam de transformações e uma mente que precisa desenvolver-se para poder conter os conteúdos impensáveis (BION, 2004). As questões referentes à sua cirurgia permanecem vivas em sua mente, esperando serem integradas, bem como suas angústias referentes a elementos destrutivos, rivalidade, ódio e inveja. Sofia não sabe o que fazer com tantos conteúdos, vomita.

Sofia aparece concretamente recortada e, em uma das sessões, culpabiliza sua mãe pelo corte no peito, o qual olha com dor. Dor psíquica. Sofia foi ferida e nesse ferimento arrancaram-Ihe tudo, ficou sem bebê. Questiono, a partir da experiência de 
sua hospitalização, a confiança dela no vínculo, no cuidado. Nas sessões eu estou com bebês e ela sem, esvaziada, castrada o que mobilizava nela alguns desses sentimentos - inveja, rivalidade, destrutividade. Muitas vezes, o tom dos encontros com Sofia era de continência aos conteúdos violentos e destrutivos que, por identificação projetiva, eu captava. Por vezes, as sessões eram densas, me sentia confusa e perdida com as falas de Sofia que evacuava (vomitava) muitos conteúdos de uma só vez, sua fala me soava desconexa e me sentia incapaz de pensar. As sessões com Sofia exigiam tolerância ao não saber e, nesses momentos, com paciência, eu procurava colorir as sessões com amorozidade, acolhimento e continência. Vez ou outra, seus desenhos produziam angústia tal que eram encobertos, como na sessão descrita acima, ou transformados, como as pinturas de Picasso.

As sessões com Sofia demoraram um período maior até que pudessem ser finalizadas, houve muitos desencontros (ora a mãe esquecia-se de trazê-la, ora porque coincidia com feriados, ora não podia faltar à escola, ora porque Sofia resfriara) o que fez com que ela acompanhasse um período de evolução e avanço da minha gestação. Com isso, Sofia pode ter sentido, na nossa relação (também em razão da minha gravidez), escassez e sede, como sentia, às vezes, na relação com sua mãe. Com relação a esse aspecto, o da falta, a própria questão dos nossos encontros com tempo limitado pode ter sido também mobilizador de angústia. Era evidente que Sofia, tal qual Igor, gostaria de que dispuséssemos de mais tempo juntos.

A possibilidade de colar partes e pedaços apareceu em algumas sessões. Sofia recortava e colava, ligava com barbantes, fazia-me deitar à maca e prestava auxílio à minha condição, ora de paciente sadio, ora de doente. Ficavam claras as tentativas de Sofia em lidar com aspectos de sua hospitalização. Todavia, algo da sua relação com a mãe me intrigava, sobremaneira, algo que talvez tivesse se acentuado depois da operação. Talvez, Sofia não encontrasse na mãe continência e acolhimento, o que ficava evidente quando Sofia ficava angustiada ou ansiosa e vomitava. Mostrava sintomas de desidratação (febre, dor de cabeça, vômito). A nosso ver, talvez Sofia estivesse desidratada emocionalmente e esses sintomas pioraram depois da hospitalização. 
$\mathrm{Na}$ história das duas, que a princípio me pareceu uma mistura, mãe e filha tinham um "buraco" no coração (comunicação interventricular e interatrial), mas somente a filha passou por cirurgia. Sofia também sofria de persistência do canal arterial, um canal que é importante na gestação para a passagem de oxigênio da mãe para o feto, mas que é fechado depois que o bebê nasce. No caso de Sofia, o canal persistiu aberto e foi corrigido na sua operação. Seria possível dizer que Sofia estava se separando e teria a possibilidade de se discriminar da mãe, após a operação com um alto custo?

Pensamos que as dificuldades da mãe, em acolhê-la, podem estar relacionadas à culpa por gerar uma filha cardiopata, tal como ela. As feridas narcísicas são tantas que Sofia estava sendo curada e cuidada diferentemente da mãe, o que a nosso ver, poderia dificultar ainda mais a sintonia mãe-filha e a possibilidade de a mãe ser continente com as angústias da criança.

A hospitalização e os dias em unidade de terapia intensiva estreitaram ainda mais um continente que, no mundo de Sofia, já se encontrava comprimido. Sofia me pedia sempre para que fizesse os desenhos junto dela e como ela. Penso que me pedia para acompanhá-la em seu mundo de temores e angústias. Os potes de tintas que distribuía para si e para mim ajudavam-nos a escrever a sua história e permitia que, a meu modo, junto dela, essa história fosse, em um ou outro traço, modificada. Por vezes, as identificações projetivas eram tantas que me encontrava distante de Sofia, com algumas oscilações no par continente-contido. Imaginava que tais estados colocavam nossa relação muito próxima da relação que Sofia mantinha com sua mãe. Aos poucos, discriminava-me dessa parceria, recebia a comunicação de Sofia e voltávamos para uma relação em que pudéssemos usufruir um continente com elasticidade.

Ao final dos atendimentos, Sofia encanta-se com a possibilidade de ganhar um "cachorrinho-bebê" e passa algum tempo falando em como cuidar do filhote, que ela tratava como bebê, planejando e contando suas expectativas. O espaço de acolhimento e continência que Sofia teve, por alguns momentos, possibilitou que pudéssemos falar de conteúdos bons, de vínculo e cuidado de uma maneira que Sofia não se sentisse 
mais tão esvaziada. A esperança dos nossos encontros talvez tenha fertilizado a possibilidade de Sofia ter seus bebês de volta.

Nos desenhos de sua última sessão, o coração desenhado ganha um contorno e está junto com outro (anexo 4), não está mais só, no entanto, produz estórias e verbalizações com conteúdos invejosos, maus e de abandono. Penso que Sofia estava dizendo da nossa separação, de como era difícil pra ela saber que eu teria um bebê e de quantos sentimentos isso despertava nela - ansiava por ser este bebê que eu acolheria e que não se afastaria como ela.

Provavelmente, como Igor, Sofia se beneficiaria de análise se fosse possível, no entanto, acreditamos que foi possível um movimento. Sofia se beneficiou das intervenções e do que foi possível lidarmos nos nossos encontros, mesmo com conteúdos à espera para serem trabalhados, como as questões referentes à castração e à indiscriminação entre ela e a mãe. A irritação e o nervosismo melhoraram durante os nossos primeiros encontros, enquanto os vômitos e as dores de cabeça demoraram algumas sessões até que fossem diminuídos. Acreditamos que uma melhora tenha sido possível porque seus conteúdos ganharam um espaço para serem acolhidos. 


\section{4 - DISCUSSÃO DOS CASOS ATENDIDOS}

A disponibilidade de acolher os conteúdos emocionais de uma mente em relação é condição ímpar para que a mente se desenvolva (FERRO, 1995). Ferro (1995) nos diz que duas mentes estão em relação juntamente dos fatos emocionais que nelas ocorrem e que as transformações poderão ser fruto dos movimentos emocionais e relacionais da dupla, não mais somente de interpretações verbalizadas. Essa dupla está empenhada em se defender da possibilidade de que o perigo se transforme em terror sem nome, bem como também, no desenvolvimento da própria mente. Nesse sentido, tanto o trabalho com Igor, quanto o trabalho com Sofia envolveu mais o desenvolvimento do continente do que do conteúdo.

Estar em uníssono com o paciente (FERRO,1995), ou seja, na mesma tonalidade afetiva e oferecer um espaço de continência foram aspectos fundamentais que embasaram as nossas intervenções. Com Igor, a cena de não ter tido braços que o segurassem no início de sua vida representa, a nosso ver, quase pictoricamente, a falta desta segurança e confiança no objeto. Nesse sentido, a massinha que era jogada para o alto representava uma tentativa de poder contar com a presença de alguém que segura, acolhe e contém. Esta falta pode ser expressa por meio de uma carência de continente e de rêverie. Sofia também sofria destas carências, vomitava seus conteúdos nas sessões e fora dela.

A nosso ver, essas carências, que puderam ser verificadas nos dois pequenos pacientes, são faltas importantes, uma vez que são fundantes, diretamente relacionadas com o desenvolvimento do psiquismo. A falta de poder contar com um objeto materno que pode acolher e transformar angústias inominadas, reverberará ao longo de toda uma vida, caso não seja possível modificar a história de ambos. Como dissemos no início deste trabalho, desde o começo da vida, o psiquismo, em formação, depende das primeiras experiências e de experiências da primeira infância para se constituir. Isso implica a constituição de um tecido representacional, a partir de 
experiências de objeto que sejam seguras e de satisfação. $\mathrm{Na}$ ausência de tecido representacional, o psiquismo não tem capacidade de gerir experiências, elaborá-las, dar um sentido e simbolizá-las, especialmente, se estas forem de qualidades traumáticas.

Tanto Igor quanto Sofia dispõem de uma mente que não tem recurso para lidar com os estímulos aos quais são expostos. Primeiro, porque falta na mente uma função alfa operante, que teria que estar sendo introjetada, pelas capacidades de rêverie e função alfa materna operante (FERRO, 2005). Dizemos "estar sendo" porque nas crianças o aparelho psíquico está ainda em formação. Segundo, pelo montante de estimulação sensorial a que estiveram expostos (devido à hospitalização e `as cirurgias) que mesmo para um psiquismo maduro seria o suficiente para a mente não conseguir gerir. Segundo Ferro (2005), é traumática qualquer situação que determine mais elementos beta do que podem ser transformados em alfa. Dificultando a transformação, esses elementos não podem ser tornados como pensáveis. Poderíamos inferir que uma quantidade menor de estímulos seria suficiente para exceder as capacidades de a mente suportar, uma vez que o psiquismo da criança, em formação, é dotado de menos recursos. Ademais, durante o desenvolvimento, a criança tem que lidar com outros aspectos traumáticos inerentes à infância, como a ameaça de castração, mais claramente observados em crianças submetidas à cirurgia e à hospitalização.

Entrementes, tendo isto sido exposto, em ambos casos atendidos, podemos supor que faltou um aparelho mental razoavelmente desenvolvido para dar conta destas experiências. Igor e Sofia já não dispunham, antes da operação cardíaca, de uma mente capaz de se desenvolver adequadamente, que tivesse capacidade para lidar satisfatoriamente com os aspectos da hospitalização e cirurgia, mediante recursos de simbolização. Igor, com seu início de vida conturbado, tinha inibições no seu desenvolvimento e Sofia, ao menor sinal de angústia, vomitava, não podia conter seus conteúdos. Imaginamos como ficou o mundo interno de Sofia e de Igor, uma vez que, para elaborar a quantidade de estímulos suscitados com a hospitalização, seguida de uma operação de grande porte e dias de internação em unidade de terapia intensiva, 
seria preciso um psiquismo dotado de função alfa o suficiente para transformar tantos conteúdos, experiências sensoriais brutas, em elementos mais digestos ao psiquismo.

Por tais razões, após experiências de qualidades traumáticas, pareceu-nos mister o oferecimento de um espaço de continente com rêverie. Acreditamos que este pôde propiciar a metabolização das angústias inominadas em algo mais pensável, passível de melhor acomodação na mente de Sofia e de lgor.

Bion (1963/2004) utiliza o par continente-contido como um dos elementos chave da psicanálise para referir-se a algo que é contido por outro algo, como o desconforto de um bebê quando é apaziguado pela vinda de uma mãe que o acolhe em suas necessidades. Essa dupla, em sintonia, é fundamental para o bom desenvolvimento das capacidades de pensamento e de outras funções, como o aprendizado juntamente com a capacidade de rêverie.

O continente com rêverie favorece o desenvolvimento da função alfa na criança. As angústias da criança são evacuadas na mente da mãe e necessitam de um acolhimento e de transformação. Acolhendo e nomeando as angústias da criança com devoção, paixão e cuidado a mãe transforma-as e as devolve à criança. Por meio desse processo, as protosensações (elementos beta) vão sendo modificadas em elementos alfa, de modo que a função alfa da mãe pode operar no desenvolvimento de uma função alfa na mente da criança. Esse modelo, de um contínuo jogo de projeções e introjeções da relação mãe-criança, serve para a relação da dupla na sessão (paciente e analista). Os elementos beta (experiências sensoriais brutas, desprovidas de significado) podem ser tratados e bonificados, transformados em elementos alfa (impressões visuais, olfativas, auditivas, elementos de experiências que podem ser ligados entre si) por meio da função alfa do analista, com intuito de dotar a experiência emocional do paciente de significado (FERRO, 2005).

Quando Sofia pinta seus desenhos e pede para ser acompanhada, imaginamos que Sofia pede uma parceria para enfrentar seus temores, no desejo de enfrentar seus pesadelos para poder sonhar (OGDEN, 2010). Também é possível verificar os elementos contidos na sessão quando, diante de um montante de desenhos e pinturas 
desconexas, Sofia vislumbra e desenha uma cobra que aparece e desaparece junto com a mistura de tinta preta, um início de significado. Da angústia inominada pode emergir uma cobra brava, o preto e o cinza, bem como, aspectos da sua hospitalização. Sobre este último, Sofia pôde se aproximar mais do que Igor. Nos atendimentos propostos por Ferro (1995), o analista coloca-se no lugar das histórias e dos jogos possíveis, prestando-se aos papéis emocionais que o campo necessita, como a necessidade de Sofia de estar no papel de médica e examinar um doente, cuidando de suas dores.

Acreditamos que a premissa de estar em uníssono com o par na sessão e o continente com rêverie são facetas de um lugar apropriado para que as necessidades emocionais dos pacientes possam ser atendidas e, a partir dos movimentos emocionais da sessão, haja transformação das angústias por meio da construção de novos sentidos.

Bleichmar (2005) expõe que novas constelações simbólicas podem ser produzidas por meio da prática analítica e, especialmente na infância, essa trama simbólica pode ser fundadora de instâncias. Nas sessões com lgor, a repetição de algumas cenas e movimentos foi marcante, bem como a possibilidade de vislumbrarmos, além dela, algo novo. Acreditamos que, por meio da repetição, Igor tenta lidar com aspectos traumáticos do seu psiquismo que luta, em um esgotante trabalho, para sobreviver, confrontando-se, desde muito cedo, com o abismo do irrepresentável. Apoiamos-nos em Botella e Botella (2002) quando consideram que essas tentativas de sobrevivência do psiquismo já são antitraumáticas, como um início de elaboração, ainda que não sejam determinações simbólicas que levariam `a representabilidade. Todavia, por meio das intervenções psicanalíticas, esse algo novo pôde, sutilmente, emergir.

Acreditamos que a possibilidade da construção de sentidos se dá por meio do brincar. Segal (1991) menciona que o símbolo, implícito nas noções de busca de sentido, pode ser uma imagem, uma palavra ou uma representação plástica. Sofia pôde, por meio de suas pinturas, recortes, colagens, lidar com aspectos da sua 
hospitalização, relacionados com a ameaça de castração e fertilizar seus bebês. Igor pôde comunicar seus acidentes trágicos, seus encontros e desencontros, sentir-se seguro, acompanhado e contido e, então, continuar a se desenvolver - esses aspectos, a nosso ver, denotam a emergência do novo. O que o possibilita é, especialmente, o brincar em conjunto, a busca do movimento do psiquismo, em detrimento do congelamento e paralisação.

Sob este ponto, da emergência do novo, gostaríamos de enfatizar a produção dos desenhos e das estórias. Os desenhos e estórias solicitados durante as intervenções, no início e no final delas, foram utilizados como recurso de pesquisa. Nosso interesse foi verificar possíveis modificações na maneira de as crianças se expressarem graficamente antes e depois das intervenções. Entretanto, o desenho também mobilizou as capacidades elaborativas dos pequenos pacientes. Os desenhos de Igor (anexo 1 e anexo 2) se modificaram enormemente quando comparados. Apesar de a estória ter elementos semelhantes, os conteúdos de seus desenhos são díspares. Igor sai do caos do seu primeiro desenho, em rabisco, para esboçar, no seu desenho final, um contorno.

Mèredieu (2001), em pesquisa sobre a evolução do desenho infantil, escreve que o rabisco aparece como uma das primeiras manifestações da criança no plano gráfico, juntamente com a aprendizagem do andar e está ligado à apreensão do eixo corporal, ou seja, do sentido de equilíbrio. Em crianças menores, por volta dos dezoito meses, o rabisco está relacionado à simples excitação motora e, à medida que a criança cresce, por volta dos dois e três anos, o rabisco torna-se mais lento, descontínuo e como tentativa para reproduzir algo. Mais tarde, na criança de três e quatro anos, o rabisco evolui e aparece como uma tentativa de escrever e se comunicar reproduzindo as letras dos adultos para então, finalmente, desaparecer sendo substituído por produções mais complexas, como a figura do boneco. Nesse momento, a criança começa a ter noção do espaço gráfico e essa aquisição está intimamente relacionada à conquista de outros espaços. No rabisco a noção de espaço é nebulosa, espaço e objetos estão indistintos, bem como continente de conteúdo. Também por esta razão, o autor menciona que o 
rabisco persiste apenas a título de anomalia ou integrado à figuração, como um detalhe ou ornamento do desenho.

Acompanhamos nas produções gráficas de Igor uma evolução. No seu primeiro desenho, em rabisco, fica evidente a produção por simples descarga motora e evolui, sutilmente, para tentativa de reprodução de algo, com um rabisco mais regular e descontínuo. Ao final, Igor desenha um contorno, além de tentar escrever seu nome. Podemos pensar no desenho, ao final das sessões, como um início de discriminação de Igor e, uma vez que desenha um contorno, delimita um espaço e expressa um continente. Além do desenho fechado, desse contorno, Igor desenha buracos.

Rodulfo (1990) apresenta a problemática dos buracos em um contexto diferente daquele tradicionalmente relacionado como carência (contexto, este, oportuno para pensarmos sobre o buraco no coração de Sofia) e que serve de modelo para refletirmos o desenho final de Igor: "para ser, deve-se esburacar" (RODULFO, 1990, p.82). $\mathrm{Na}$ visão de Rodulfo (1990), o bebê precisa esburacar para nascer, atravessar um canal de parto, metáfora utilizada pelo autor para designar todo desenvolvimento ulterior. $O$ autor relata que as atividades intensas e regulares dos bebês, no primeiro ano de vida, consistem na produção de buracos, com predileção ao corpo do Outro primordial, a mãe - dar puxões, arrancar, extrair. Ao esburacar o corpo do Outro, o bebê retirará componentes para se unificar e, dessa maneira, a produção de um buraco "constitui uma positividade fundamental no subjetivo" (RODULFO, 1990, p. 86). Tendo em vista essas considerações, podemos inferir que o desenho de lgor comunica-nos dos recursos que ele pode desenvolver, após os encontros. Antes de ser trazido para as sessões, ele era descrito pelos pais e, especialmente, pela professora como uma criança alheia ao mundo, como se não tivesse noção do que the acontecia ao redor, como se não acompanhasse e não absorvesse o que vivia. Essa criança nos parece agora inserida neste mundo, uma vez que the é dada a condição de existir, com um coração revitalizado e peso-carne o suficiente para se sustentar.

Para além de um instrumental de pesquisa, o desenho se configurou em um recurso capaz de atribuir significado e símbolo aos elementos do psiquismo desses 
pacientes. Os desenhos de Sofia também demonstraram uma variação (anexos 3 e 4). Assim como pôde ser observado nos desenhos de Igor, o desenho final de Sofia (anexo 4) também expressou um contorno. Sofia apresentou seu desenho em partes que formou um todo e, dentro do todo, um coração que pareceu movimentar-se, vivo. $\mathrm{Na}$ outra metade do desenho, um coração em companhia de outro.

Por intermédio dos desenhos de Igor e Sofia, podemos supor que ambos tiveram um movimento. Como proposta inicial do estudo, questionamos a possibilidade de movimentação psíquica sem nos esquecer de que propusemos um setting diferenciado. Ao relembrarmos as questões referentes a intervenções em contextos clínicos diferenciados, como mencionamos no início deste trabalho, nossa ênfase recai para a função analítica. Foi possível usarmos os conhecimentos psicanalíticos e a função analítica em benefício dos pacientes, mesmo fora do consultório, mesmo com tempo limitado. Salvaguardamos os aspectos referentes ao tempo. Tanto Igor quanto Sofia gostariam que dispuséssemos de mais tempo e, muito provavelmente, beneficiar-seiam ainda mais se assim o fosse. Em alguns momentos dos atendimentos, chegamos a nos questionar o fator tempo como sério limitador, pelo fato de ser mobilizador de mais angústias, tanto para o analista quanto para o paciente (vide entrevista clínica nove com Igor). Seguimos acreditando, a partir da experiência, que as questões referentes ao tempo, uma vez cuidadas internamente pelo analista, podem ser manejadas no contexto clínico com o paciente e, desse modo, o tempo, ainda que limitado, pode atuar em favor destes pacientes que não dispõem de recursos para um atendimento clínico a longo prazo.

Tem-se presente que, em qualquer situação de intervenção clínica, com tempo breve ou não, a orientação dos pais afigura-se como um recurso fundamental. São mais do que coadjuvantes no processo, especialmente, quando as intervenções são com tempo limitado. Dois aspectos merecem consideração: não há como os pais ficarem de fora das intervenções psicanalíticas. Isto não é novo, dentro do âmbito psicanalítico, mas não poderíamos deixar de repetir. Cremos, a partir desta vivência, que as crianças submetidas a estas situações precisam de um objeto materno íntegro e pronto, mas, entretanto, nem sempre, em um pós-operatório, este objeto materno está disponível, 
em função das angústias e ansiedades que os pais têm que enfrentar. A orientação de pais e o acolhimento dos mesmos na entrevista têm máxima relevância. Nesse sentido, as sessões com os pais de Igor foram fundamentais ao desenvolvimento dele, contributivas para o desenvolvimento da continência e, sobretudo, para o entendimento do movimento de uma mãe que não queria vê-lo crescer. Ambos pais se mostraram disponíveis e participativos, não ofereceram resistência ao processo, pelo contrário, procuraram integrá-lo. Outro ponto é que as intervenções com os pais precisam ser pontuais, não perdendo de vista o tempo limitado que temos disponível com eles, contudo, sem serem por demais invasivas. Alguns pais conseguem, somente até certo ponto, participar ativamente da melhora de seus filhos, isso porque as intervenções psicanalíticas são mobilizadoras de angústia não somente para os pequenos pacientes, mas também para eles.

Neste ponto, a mãe de Sofia deixou de trazê-la para algumas sessões, por vezes se "esquecia", por outras imaginava que não haveria o encontro, também chegou a relatar outras situações impeditivas de comparecer ao atendimento. Ao final, diversas tentativas de encontrar a mãe para o encerramento do processo foram frustradas, restando, somente, uma conversa final por telefone. Poderíamos explorar as motivações destas faltas, mas gostaríamos apenas de enfatizar que muitos desdobramentos podem surgir na entrevista com os pais capazes de aproximá-los ou afastá-los, de mobilizar reações positivas ou negativas, ainda que regidas por um determinismo inconsciente, tanto em situações convencionais de análise ou intervenções com setting diferenciado. Ficamos dependentes dos pais e esperamos que eles sejam colaboradores, todavia, por mais cautelosa e cuidadosa que possa ser a citada entrevista, eles podem interromper ou atrapalhar o processo de melhora dos filhos.

Estabelecer um diálogo fecundo com os pais para que entendam melhor a dinâmica emocional da interação com seus filhos também é buscar um movimento, uma vez que os dinamismos psíquicos dos pequenos pacientes estão intimamente relacionados a eles. 


\section{CONSIDERAÇÕES FINAIS}

Os encontros com Igor e Sofia fortaleceram as propostas iniciais desse estudo: oferecer um continente, um espaço que possibilitasse a mobilidade de seus conteúdos psíquicos no sentido de não paralisar e não congelar, ainda que em um curto espaço de tempo. Também foi possível investigar a dinâmica psíquica destes pacientes expostos a enfermidades graves.

Partimos da premissa de que a enfermidade grave atua como um elemento traumático, uma vez que os estímulos a ela relacionados remetem a violência - causa um excesso, inverte os sentidos esgarça as capacidades de compreensão. Todavia, se o trauma sempre tem elementos traumáticos, nem sempre os elementos traumáticos culminam no trauma. Entendemos aqui o trauma tal como é compreendido nas idéias de Cesar e Sara Botella (2002), como uma negatividade, uma desorganização brutal marcada pela ausência de sentido e de vazio, "uma violenta e brusca ausência de tópicas e das dinâmicas psíquicas, a ruptura da coerência psíquica, o desmoronamento dos processos primários e secundários" (p.93).

Dentro deste contexto, lançamos um olhar para crianças que, como Igor e Sofia, quando acometidas de doença grave e submetidas a operações invasivas potencialmente desorganizadoras, somadas a inúmeras outras situações difíceis de sobrevivência, não são crianças que desenvolvem um trauma, e sim, crianças que lutam contra os efeitos estarrecedores das experiências traumáticas.

Os tópicos que procuramos desenvolver neste trabalho buscaram elucidar como as crianças lutam e reagem diante de fortes estímulos em um esforço para não sucumbirem o seu psiquismo ao congelamento e à paralisação. Nossa investigação

partiu das primeiras inscrições e de como se forma um tecido representacional no psiquismo, o qual o indivíduo dependerá para lidar com as experiências ulteriores. Em 
seguida, a citada investigação percorreu o campo do traumático, cuja aridez se fez presente por meio da violência do excesso de estímulos e, como conseqüência, pela possibilidade do aparelho psíquico ficar estanque. Diante de tal ameaça, propusemos a fertilização deste terreno mediante a transformação do pesadelo em sonho (OGDEN, 2010), em outros termos, uma busca de sentidos, de criação de elementos alfa, por intermédio do brincar como recurso primeiro na construção do simbólico, como equivalente ao sonho. Também em busca de fertilização se priorizou as intervenções psicanalíticas pautadas no continente com rêverie.

Estas crianças, cujo aparelho mental necessita suportar um expressivo montante de estímulos, precisam, demasiadamente, de um objeto materno que possa servir de continente e operar como metabolizadora de estímulos. As intervenções psicanalíticas tiveram este intuito, não de eliminar o traumático, mas de propiciar a transformação de alguns elementos, a partir do surgimento de novos, por meio da não paralisação e do não congelamento de suas redes simbólicas.

Com este trabalho lançamos um olhar para as intervenções psicanalíticas em contextos diferenciados, certos de que a mudança do setting não implica que o referencial interno se desvaneça. Manter função analítica é fazer com que as intervenções psicanalíticas possam acontecer, ainda que em um espaço breve de tempo, ainda que fora do contexto clássico do consultório, sem que nos esqueçamos das particularidades e desafios deste tipo de encontro. Nesse sentido, futuros aprofundamentos contribuiriam para o desenvolvimento deste campo de atuação, certos de que este estudo é apenas uma semente em solo fértil.

Igor e Sofia beneficiar-se-iam de uma análise, mas, na ausência dessa possibilidade, as intervenções psicanalíticas possibilitaram um encontro genuíno, um espaço ofertado com cuidado, elasticidade e continência para que ambos pudessem falar de suas angústias, narrarem suas histórias e modificá-las, um pouco, por meio do brincar. 


\section{REFERÊNCIAS BIBLIOGRÁFICAS}

ALVAREZ, A. Além do Princípio do Desprazer: o brincar e o simbolismo. In: Companhia Viva: psicoterapia psicanalítica com crianças autistas, borderline, carentes e maltratadas. Porto Alegre, Artes Médicas, 1994, p.173-83.

ALVAREZ, A. Entrevista com Anne Alvarez. In: Jornal de Psicanálise Instituto de Psicanalise SBPSP Psicanálise Sem Divã, v. 30, n.55/56, 1997, p.305-16.

AMARO DA SILVA, F. C. Ameaças à Infância: do trauma psíquico ao transtorno de estresse pós-traumático. Dissertação de Mestrado. Pontifícia Universidade Católica de São Paulo PUC-SP, 2006.

BARONE, L. M. C. Psicanálise Sem Divã: desejo e aprendizagem da leitura e da escrita. Jornal de Psicanálise Instituto de Psicanalise SBPSP Psicanálise Sem Divã, v. 30, n.55/56, 1997, p.109-23.

BARROS, E. M. R. Botella, Ogden, Green, Ferro, Bion Comentário à Entrevista de Cesar Botella. Revista Brasileira de Psicanálise, v. 41, n. 1, 2007, p. 33-45.

BARROS, E. M. R. O Processo de Constituição de Significado na Vida Mental: Afeto e imagem pictográfica. Revista Brasileira de Psicanálise, v. 31, n. 1, 2000, p.55-65.

BION, W. R. Elementos de Psicanálise (1963). [trad. Jayme Salomão]. Rio De Janeiro: Imago, 2004, 2 ${ }^{\mathrm{a}} \mathrm{Ed}, 120 \mathrm{p}$.

BIRMAN, J. A Clínica na Pesquisa Psicanalítica. Psicanálise e Universidade, Núcleo de Pesquisa em Psicanálise Programa Estudos Pós-Graduados em Psicologia Clínica da PUC-SP, n. 2, 1994, p.7-37.

BLEICHMAR, S. Clínica Psicanalítica e Neogênese. São Paulo: Annablume, 2005, 326p. 
BOLOGNINI, S. A Coragem de Ter Medo. In: Psicanálise e Cultura: uma homenagem aos 150 anos de Sigmund Freud. Sociedade de Psicanálise de Porto Alegre (Org.) São Paulo: Casa do Psicólogo, 2007 p.59-85.

BOTELLA, C \& BOTELLA, S. Irrepresentável: mais além da representação. [trad. Maria Elisabeth Judice do Nascimento Schneider, Patricia Chittoni Ramos e Vanise Dresch] Porto Alegre: Criação Humana, Sociedade de Psicologia do Rio Grande do sul, 2002, 240p.

CAPER, R. O Brincar, a Experimentação e a Criatividade. [trad. Eliana Bastos Neves] Livro Anual de Psicanálise 1996, v.12, São Paulo: Escuta, p. 129-38.

CAPER, R. Tendo Mente Própria Uma Visão Kleiniana do Self e do Objeto. [trad. Haroldo Pedreira e outros] Rio de Janeiro: Imago, 2002, 240p.

FERENCZI, S. Bandagem Psíquica (1932). In: __. Diário Clínico. [tradução Álvaro Cabral] São Paulo: Martins Fontes, 2. ed., 2003, p.104-06.

FERENCZI, S. Confusão de Línguas entre os Adultos e a Criança, A Linguagem da Ternura e da Paixão (1933). In: . Sandor Ferenczi Obras Completas Psicanálise IV. São Paulo: Martins Fontes, 1. ed. 1992, p. 290.

FERRO, A. A Técnica na Psicanálise Infantil: a criança e o analista da relação ao campo emocional. [trad. Mercia Justum] Rio de Janeiro: Imago, 1995, 224p.

FERRO, A. Fatores de Doença e Fatores de Cura - gênese do sofrimento e da cura psicanalítica. [trad. Marta Petricciani] Rio de Janeiro: Imago, 2005, 180p.

FERRO, A. Na Sala de Análise: emoções, relatos, transformações. [trad. Mercia Justum] Rio de Janeiro: Imago, 1998, 252p.

FONSECA, V. R. J. R. M. Considerações sobre a Pesquisa Psicanalítica. Jornal de Psicanálise Instituto de Psicanalise SBPSP Psicanálise Sem Divã, v. 30, n.55/56, 1997, p.39-46. 
FONSECA, V. R. J. R. M.; BUSSAB, V. S. R. Possibilidade de Pesquisa em Psicanálise. Revista Brasileira de Psicanálise, v.35, n.3, 2001, 873-93.

FRANÇA, J. B. N. F. Psicanálise "fin-de-siècle" Crise Ressonâncias e Perspectivas. Jornal de Psicanálise Instituto de Psicanalise SBPSP Psicanálise Sem Divã, v. 30, n.55/56, 1997, p.135-43.

FRANÇA, J. B. N. F. Psicanálise "fin-de-siècle" Crise Ressonâncias e Perspectivas. Jornal de Psicanálise Instituto de Psicanalise SBPSP Psicanálise Sem Divã, v. 30, n.55/56, 1997, p.135-43.

FRANÇA, M. T. B. O Terror Tem Nome: A enfermaria de crianças cronicamente enfermas. Jornal de Psicanálise Instituto de Psicanálise SBPSP Psicanálise Sem Divã, v. 30, n.55/56, 1997, p.229-35.

FREUD, S. Além do Princípio do Prazer (1920). In:___. Além do princípio do Prazer Psicologia de Grupo e Outros Trabalhos (1925-26) Rio de Janeiro: Imago, 1996g, v.18 (Edição Standard Brasileira das Obras Completas de Sigmund Freud), 320p.

FREUD, S. Conferência VII O Conteúdo Manifesto dos Sonhos e os Pensamentos Oníricos Latentes. In: . Conferências Introdutórias sobre Psicanálise Partes I e II (1915-16) Rio de Janeiro: Imago, 1996e, v.15 (Edição Standard Brasileira das Obras Completas de Sigmund Freud), 240p.

FREUD, S. Construções em Análise. In: - Moisés e o Monoteísmo Esboço de Psicanálise e Outros trabalhos (1937-39). Rio de Janeiro: Imago, 1996f, v.23 (Edição Standard Brasileira das Obras Completas de Sigmund Freud), 351p.

FREUD, S. Extratos dos Documentos Dirigidos à Fliess. In: __. Publicações préPsicanalíticas e Esboços Inéditos (1886-89). Rio de Janeiro: Imago, 1996a, v. 1 (Edição Standard Brasileira das Obras Completas de Sigmund Freud), 495p.

FREUD, S. Formulações Sobre os Dois Princípios do Funcionamento Mental. In: O Caso Schreber, Artigos Sobre a Técnica e Outros Trabalhos (1911-13). Rio de 
Janeiro: Imago, 1996h, v.12 (Edição Standard Brasileira das Obras Completas de Sigmund Freud), 406p.

FREUD, S. Inibição Sintoma e Angústia In: Além do princípio do Prazer Psicologia de Grupo e Outros Trabalhos (1925-26). Rio de Janeiro: Imago, 1996i, v.18 (Edição Standard Brasileira das Obras Completas de Sigmund Freud), 320p.

FREUD, S. Moisés e o Monoteísmo (1934-38). In: - Moisés e o Monoteísmo Esboço de Psicanálise e Outros trabalhos (1937-39). Rio de Janeiro: Imago, 1996j, v.23 (Edição Standard Brasileira das Obras Completas de Sigmund Freud), 351p.

FREUD, S. O Inconsciente (1915). In: A História do Movimento Psicanalítico Artigos sobre Metapsicologia e Outros Trabalhos (1914-15). Rio de Janeiro: Imago, 1996c, v14 (Edição Standard Brasileira das Obras Completas de Sigmund Freud), $391 \mathrm{p}$.

FREUD, S. Os Instintos e suas Vicissitudes. In: A História do Movimento Psicanalítico Artigos sobre Metapsicologia e Outros Trabalhos (1914-15). Rio de Janeiro: Imago, 1996b, v. 14 (Edição Standard Brasileira das Obras Completas de Sigmund Freud), $391 \mathrm{p}$.

FREUD, S. Projeto para uma Psicologia Científica (1895). In: - Publicações Prépsicanalíticas e Esboços Inéditos (1886-89). Rio de Janeiro: Imago, 1996d, v. 1 (Edição Standard Brasileira das Obras Completas de Sigmund Freud), 495p.

FREUD, S. Sobre o Narcisismo: Uma Introdução. In: A História do Movimento Psicanalítico Artigos sobre Metapsicologia e Outros Trabalhos (1914-15). Rio de Janeiro: Imago, 1996k, v.13 (Edição Standard Brasileira das Obras Completas de Sigmund Freud), 391p.

GARCIA-ROZA, L. A. Introdução à Metapsicologia Freudiana. Rio de Janeiro: Jorge Zahar, 4. ed., v. 3, 2000, 295p. 
GREEN, A. Orientações para uma Psicanálise Contemporânea. [trad. Ana Maria Rocca Rivarola] Rio de Janeiro: Imago, 2008, 373p.

HERRMANN, F. Pesquisando com o Método Psicanalítico. In: Herrmann, F; Lowenkron, T. S. (org.). Pesquisando com o Método Psicanalítico. São Paulo: Casa do Psicólogo, 2004, p.43-83.

KERNBERG, O. F. A Necessidade Premente de Ampliar a Pesquisa na e sobre a Psicanálise. Livro Anual de Psicanálise, v.22, 2008, p. 25-30.

KLEIN, M. A Técnica Psicanalítica Através do Brincar: sua história e significado (1955). In:___. Inveja e Gratidão e Outros Trabalhos (1946-1963) [trad. Elias Mallet da Rocha, Liana Pinto Chaves e Colaboradores] Rio De Janeiro: Imago, 1991, v.3, (Obras Completas de Melanie Klein), p.150-68.

KLEIN, M. Princípios Psicológicos da Análise de Crianças Pequenas (1926). In: Amor Culpa e Reparação e Outros Trabalhos (1921-1945) [trad. André Cardoso] Rio de Janeiro: Imago, 1996, v. 1 (Obras Completas de Melanie Klein), p.152-63.

LAPLANCHE, J. Problemáticas I: A angústia. [tradução Álvaro Cabral] São Paulo: Martins Fontes, 3. ed. 1998, 345p.

LAPLANCHE, J; PONTALIS, J-B. Vocabulário de Psicanálise. [tradução Pedro Tamen] São Paulo: Martins Fontes, 11. ed. 1991, 552p.

LOWENKRON, T. S. A Investigação Psicanalítica está Ameaçada de Extinção? Revista Brasileira de Psicanálise, n. 3, v. 39, 2005, p.159-168.

LOWENKRON, T. S. O Objeto da Investigação Psicanalítica. In: Herrmann, F; Lowenkron, T. S. (org.). Pesquisando com o Método Psicanalítico. São Paulo: Casa do Psicólogo, 2004, p.21-31. 
MÉLEGA, M. P. O Psicanalista Trabalhando em Contextos Não-Clínicos. In: Jornal de Psicanálise Instituto de Psicanalise SBPSP Psicanálise Sem Divã, v. 30, n.55/56, 1997, p.95-107.

MEYER, L. O Método Psicanalítico. In: SILVA, M. E. L. Investigação e Psicanálise, Campinas: Papirus, 1993, p. 27-46.

MEZAN, L. Pesquisa Teórica em Psicanálise. Psicanálise e Universidade, Núcleo de Pesquisa em Psicanálise Programa Estudos Pós-Graduados em Psicologia Clínica da PUC-SP, n. 2, 1994, p.51-75.

MEZAN, L. Que Significa Pesquisa em Psicanálise? In: SILVA, M. E. L. Investigação e Psicanálise, Campinas: Papirus, 1993, p. 49-89.

MIGLIAVACCA, E. M. A Psicanálise e a Universidade - Pesquisa. Psicologia USP, n. 2, v. 12, 2001, p.119-23.

MIGLIAVACCA, E. M. Breve Reflexão Sobre o Setting. Boletim de Psicologia, v.58, n.129, São Paulo, dez, 2008.

NOSEK, L. Trauma e Elaboração. Revista Brasileira de Psicanálise, v. 39, n.1, 2005.

OGDEN, T. H. Essa Arte da Psicanálise: sonhando sonhos não sonhados e choros interrompidos. Livro Anual de Psicanálise [tradução Tânia Zalcberg] São Paulo: Escuta, v. 20, 2006, p.173-189.

OGDEN, T. H. Essa Arte da Psicanálise: Sonhando sonhos não sonhados e gritos interrompidos [tradução Daniel Bueno]. Porto Alegre: Artmed, 2010, 168p.

PARENTE, S. M. B. A. A Criação da Externalidade do Mundo. Viver Mente \& Cérebro, Edição Especial, Coleção Memórias da Psicanálise, n. 5, Winnicott Os Sentidos da Realidade, São Paulo: Duetto, s/d, p. 22-7. 
PERRON, R. Como Fazer Pesquisa? Resposta a Otto Kernberg. Livro Anual de Psicanálise, v. 22, 2008, p. 31-6.

PITLIUK, L. A Interpretação Psicanalítica: Entre o sonhar, o brincar e o viajar. In: Gueller, A. S., Souza, A. S. L. (org). Psicanálise com Crianças: Perspectivas TeóricoClínicas. São Paulo: Casa do Psicólogo, 1. ed., 2008, p.261-76.

ROCHA, F. Sobre os Afetos: Impressões e Imagens Os Afetos nas Estruturas Psíquicas e no fenômeno Psicossomático. Revista Brasileira de Psicanálise, n. 4, v. 32, 1998, p.845-63.

RODULFO, R. O Brincar e o Significante Um Estudo Psicanalítico Sobre a Constituição Precoce. Porto Alegre: Artes Médicas, 1990, 179p.

SAFRA, G. O Uso do Material Clínico na Pesquisa Psicanalítica. In: SILVA, M. E. L. Investigação e Psicanálise, Campinas: Papirus, 1993, p. 119-132.

SAFRA, G. Pesquisa com Material Clínico. Psicanálise e Universidade, Núcleo de Pesquisa em Psicanálise Programa Estudos Pós-Graduados em Psicologia Clínica da PUC-SP, n. 1, 1994, p.51-72.

SEGAL H. Notas Sobre a Formação de Símbolos. In: Melanie Klein Hoje: Desenvolvimentos da teoria e da técnica. [trad. Belinda Haber Mandelbaum] Rio de Janeiro: Imago, 1991, p.167-84.

SILVA, M. E. L. Pensar em Psicanálise. In: ___ Investigação e Psicanálise, Campinas: Papirus, 1993, p. 11-25.

SOUZA, A. S. L. S. Melaine Klein e o Brincar Levado a Sério: Rumo à possibilidade de análise com crianças. In: Gueller, A. S., Souza, A. S. L. (org). Psicanálise com Crianças: Perspectivas Teórico-Clínicas. São Paulo: Casa do Psicólogo, 1. ed., 2008b, p.123-135. 
SOUZA, A. S. L. S. Reflexões sobre a Transferência na Análise de Crianças: o enfoque kleiniano. In: Gueller, A. S., Souza, A. S. L. (org). Psicanálise com Crianças: Perspectivas Teórico-Clínicas. São Paulo: Casa do Psicólogo, 1. ed., 2008a, p.191-200.

TANIS, B. Sobre a Transferência. In: Gueller, A. S., Souza, A. S. L. (org). Psicanálise com Crianças: Perspectivas Teórico-Clínicas. São Paulo: Casa do Psicólogo, 1. ed., 2008, p.173-88.

TANIS, B. Solidão: clínica e cultura. In: Herrmann, F; Lowenkron, T. S. (org.). Pesquisando com o Método Psicanalítico. São Paulo: Casa do Psicólogo, 2004, p.8594.

TARGET, M e FONAGY, P. Brincando com a Realidade - I Teoria da Mente e o desenvolvimento Normal da Realidade Psíquica. [trad. Francisca Vieitas Vergueiro Vonk] Livro Anual de Psicanálise, v. 12, São Paulo: Escuta, 1996 p. 129-38.

TRINCA, W (org). Formas de Investigação Clínica em Psicologia: procedimentos de desenhos-estórias: procedimentos de desenhos de família com estórias. São Paulo: Vetor, 1997, 292p.

VIÑAR, M. N. Da Torre de Babel às Trilhas Fundadoras Algumas Premissas para Pesquisar no Processo Psicanalítico. Jornal de Psicanálise Instituto de Psicanálise SBPSP Psicanálise Sem Divã, v. 30, n.55/56, 1997, p.59-74.

WINNICOTT, D. W A Preocupação Materna Primária (1959). In: . Da Pediatria à Psicanálise Obras Escolhidas. [tradução Davy Bogomoletz]. Rio de Janeiro: Imago, 2000, p.399-405.

WINNICOTT, D. W. Natureza Humana (1896-1971). [trad. Davi Litman Bogomoletz] Rio de Janeiro: Imago, 1990, 222p.

WINNICOTT, D. W. O Brincar: uma exposição teórica. In: . O Brincar e a Realidade (1971). [trad. José Octávio de Aguiar Abreu e Vanede Nobre]. Rio de Janeiro: Imago, 1975, p.59-77. 


\section{ANEXO 1 - DESENHO IGOR PRIMEIRA SESSÃO}

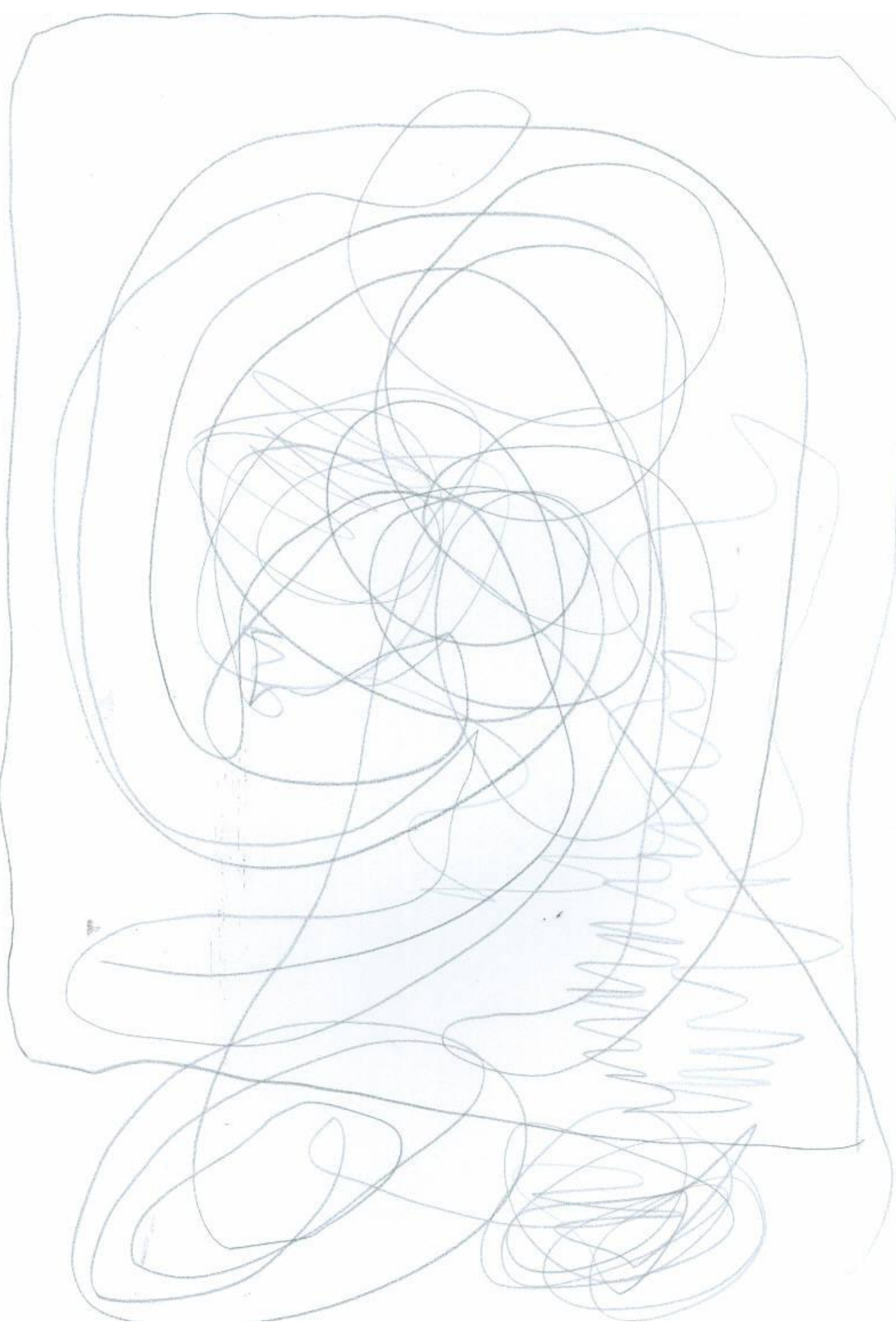




\section{ANEXO 2 - DESENHO IGOR ÚLTIMA SESSÃO}

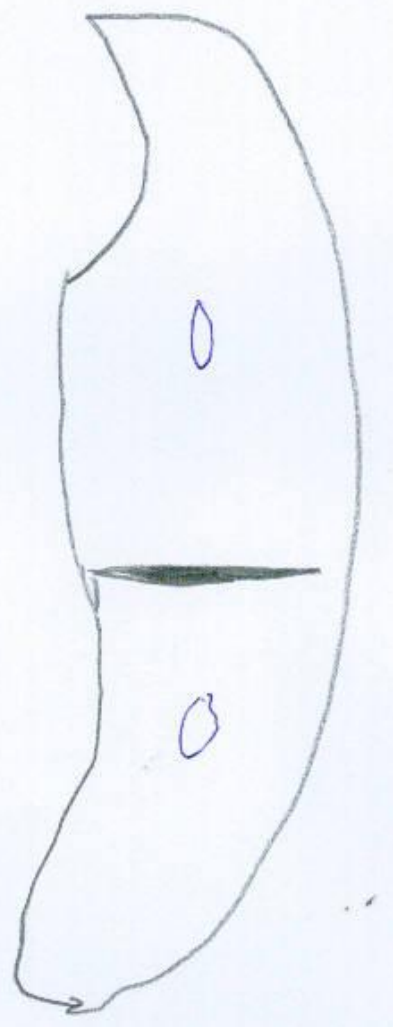


ANEXO 3 - DESENHO SOFIA PRIMEIRA SESSÃO

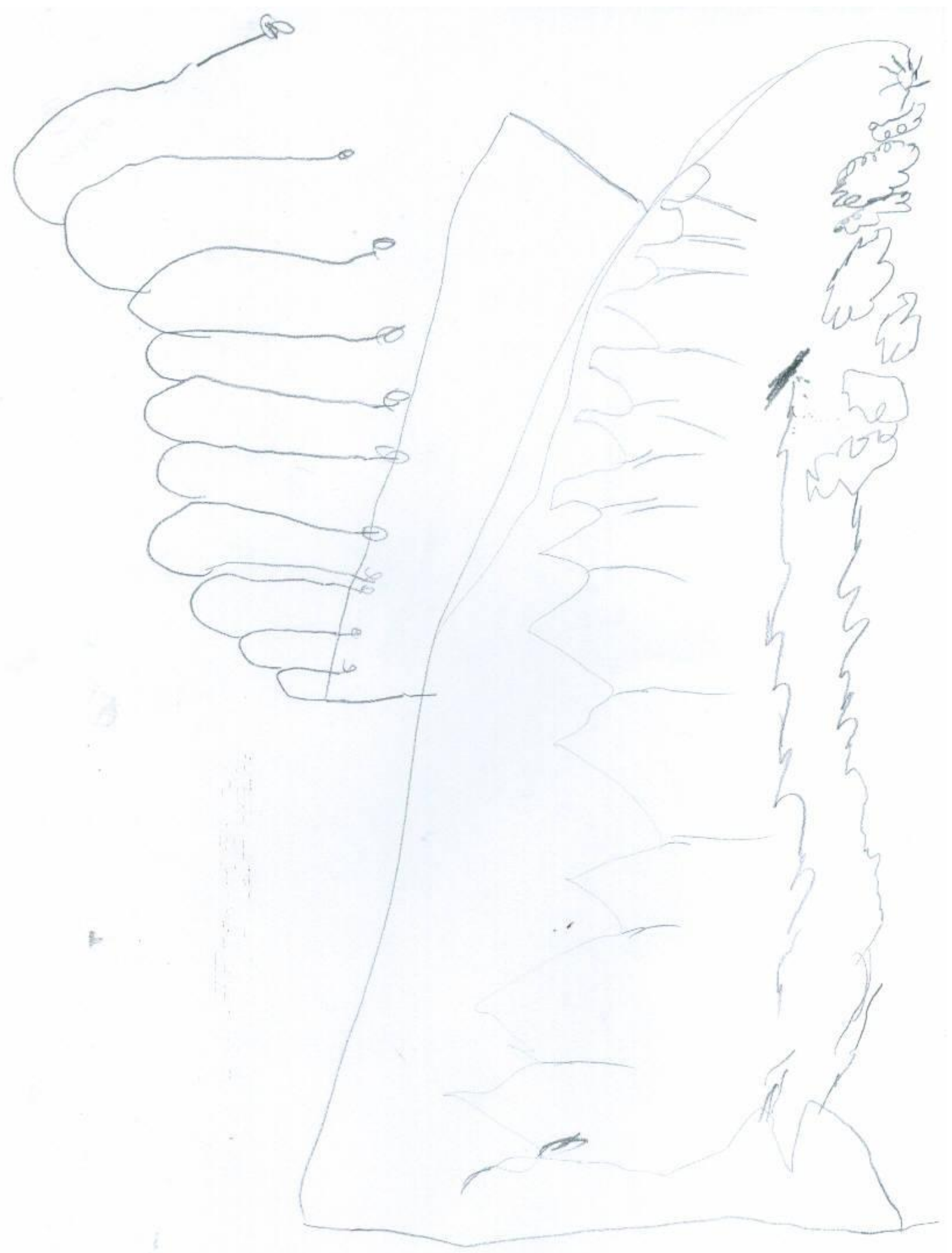




\section{ANEXO 4 - DESENHO SOFIA ÚLTIMA SESSÃO}

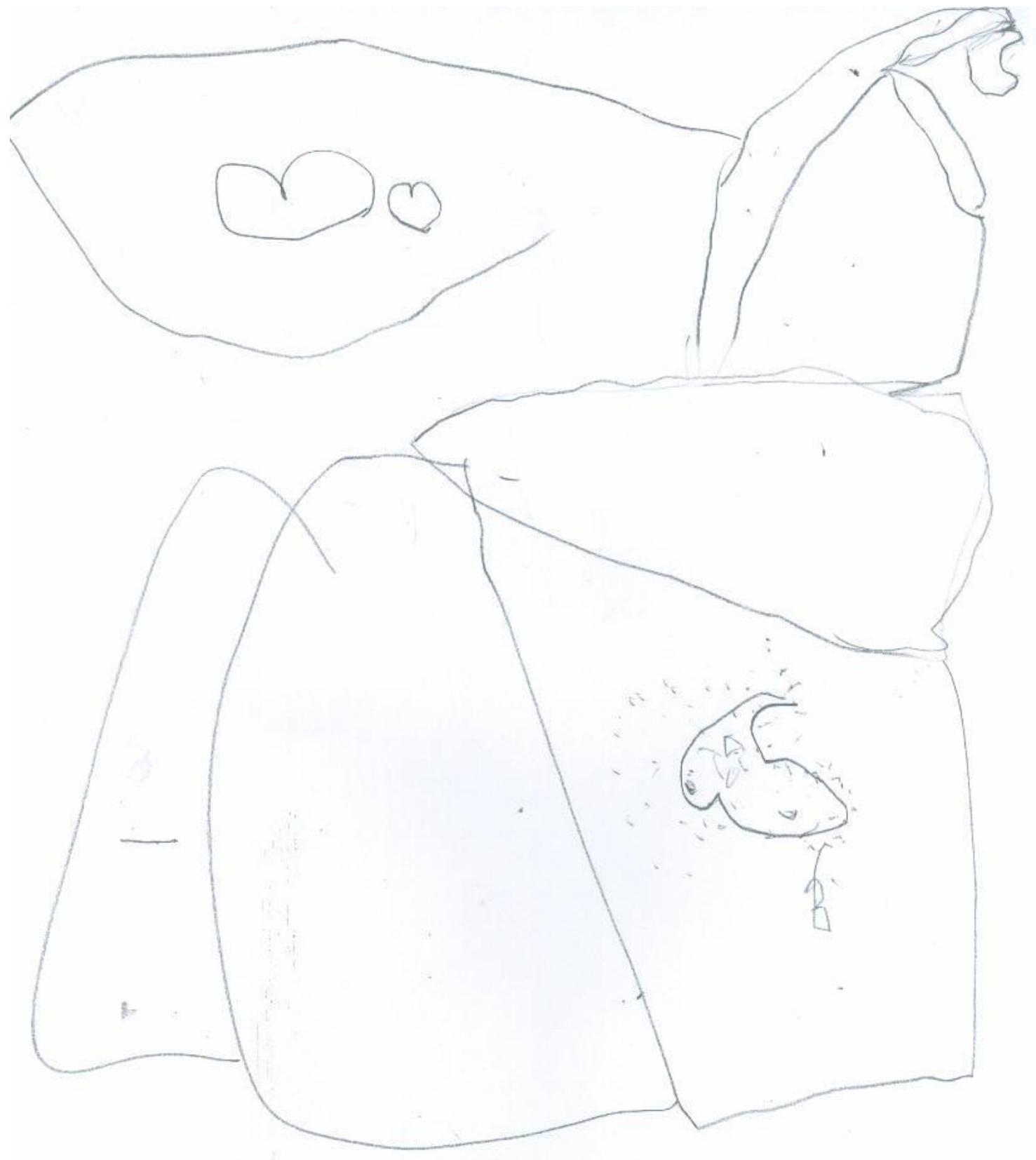

